\title{
SZCZERBIEC (THE JAGGED SWORD) - THE CORONATION SWORD OF THE KINGS OF POLAND
}

\author{
SZCZERBIEC (LA ESPADA MELLADA) - LA ESPADA DE CORONACIÓN \\ DE LOS REYES DE POLONIA
}

POR

MARCin BIBORSKI*, JANUSZ STĘPIŃSKI** AND JANUSZ StĘPIŃSKI***

\section{Abstract - Resumen}

The paper presents the results of newest research on the Szczerbiec - the Polish coronation sword. Technological examinations revealed that the blade was manufactured of bloomery steel, with C contents of c. $0.3-0.6 \%$. The blade was thermally treated (quenched and tempered) in its part below the hilt. The X-ray revealed no pattern welding or composite structures. All this testifies to the authenticity of the sword as a genuine medieval weapon and not (as sometimes suggested in scholarship) a 19th c. replica. The pommel and the crosspiece were made of silver and then coveted with nielloed gold plates.

A combination of typological, stylistic and epigraphic data suggests a date of c. 1250 for the sword. As suggested by the lavishness of ornament and inscriptions of the all-metal hilt, as well as by the rectangular cross-section of the grip, the Szczerbiec may have been influenced by swords of the Mediterranean (especially Iberian) cultural sphere. The swords of Sancho IV of Castille and Léon, of Santa Casilda, of Friedrich II von Hohenstaufen, of the Comtés de Dreux and a sword from the Museo Arqueológico Nacional in Madrid seem to be especially relevant analogies. Of particular significance is a Hebrew or Hebrew-Latin inscription on the crosspiece, which fits into a tradition of Hebrew-inspired voces magicae. The first owner of the sword was in all probability Bolesław Pobożny (the Pious), Duke of Great Poland (died 1279). For Duke Bolesław the sword was his gladius iustitiae and a protective talisman. The weapon was then inherited (probably through marriage to his daughter Jadwiga c. 1293) by Duke Władysław Łokietek (the Short or the Ell-high) (the future King of Poland). It was in all probability Duke Władysław who first used the sword as a coronation insignia.

Este trabajo presenta los últimos resultados de la investigación sobre la Szczerbiec - la espada de coronación polaca. El examen tecnológico revela que la espada se fabricó a partir de hierro forjado acerado con un contenido de carbono del 0.3-0.6\%. La espada recibió tratamiento térmico (templado y revenido) en la hoja por debajo del puño. El examen radiográfico no revela pattern welding o una estructura compuesta. Todo ello demuestra la autenticidad de la espada como una genuina arma medieval y no como una réplica del s. XIX (según se ha propuesto en ocasiones). El pomo y la guarda son de plata cubierta con placas de oro nielado.

La combinación de análisis tipológico, estilístico y epigráfico sugiere una fecha de c. 1250 d.C. para la espada. La rica decoración y las inscripciones del puño metálico, así como las inscripciones, sugieren que la espada puede haber sido influida por armas de la esfera cultural mediterránea, y especialmente de la Península Ibérica. Las espadas de Sancho IV de Castilla y León, de Santa Casilda, de Federico II Hohenstaufen, de los Condes de Dreux, y una espada del MAN de Madrid parecen paralelos especialmente relevantes. Es significativa la inscripción Hebrea-Latina en la guarda, que entronca con una tradición de voces magicae de origen hebreo. El primer dueño de la espada fue probablemente Bolesław Pobożny (el Piadoso), Duque de Polonia (fallecido en 1279). Fue para él su

\footnotetext{
* Institute of Archaeology, Jagiellonian University, Kraków..

** Academy of Mining and Metallurgy, Kraków.

*** Archeo - Logos.
} 
gladius iustitiae y talismán protector. El arma fue heredada (probablemente a través de la boda de su hija Jadwiga hacia el 1293) por el Duque Vladislao Łokietek, futuro rey de Polonia. Fue probablemente el Duque Vladislao quien por primera vez empleó la espada como insignia en la coronación.

\section{Keywords - Palabras Clave}

13th century; Poland; Duke Bolesław the Pious; King Władysław the Short; Sword; Coronation insignia; Archaeometallurgy; Epigraphy; Inscriptions; Ornaments; Song of Roland; Durendal; Talisman; Names of God; Hebrew; Latin; Voces magicae.

Siglo XIII; Polonia; Duque Boleslaw el Piadoso; Rey Vladislao; Espada; Insignia de coronación; Arqueometalurgia; Epigrafía; Ornamentos; Cantar de Roland; Durendal; Talismán; Nombres de Dios; Latín; Hebreo; Voces magicae.

\section{INTRODUCTION}

The Szczerbiec (the Jagged Sword; the Royal Castle of Wawel in Kraków, Inv. No. 137; fig. 1), being the only preserved medieval coronation insignia of the kings of Poland, has been a subject of research for almost 200 years. Regrettably, due to a language barrier, most of that research was unavailable for a wider audience. Some remarks in English on the Szczerbiec were published by a renown arms and armour scholar Andrzej Nadolski (1969), the author of the first modern analysis of this weapon (1968). Apart from that, a short note on this sword can be found in the books by $\mathrm{D}$. Nicolle (Nicolle 1999, 333, No. 921, 529, fig. 921; Nicolle 1988a, No. 1131, 421; Nicolle 1988b, No. 1131, 855). On the other hand, E. Oakeshott $(2002,41)$ simply restated erroneous assumptions made by G. Laking (1920, fig. 123, 101-103).

In early 2008, upon the initiative of Prof. Jan Ostrowski, Director of the Royal Castle of Wawel in Kraków, a series of technological analyses of the sword were carried out (a short report was submitted to Studia Waweliana). The present paper is a joint contribution by researchers from various fields: archaeology and archaeometallurgy, traseology and medieval studies. It is not meant to be the last word on the Szczerbiec, as further technological research is planned. Furthermore, an excellent paper on the sword has recently been published by the renown arms and

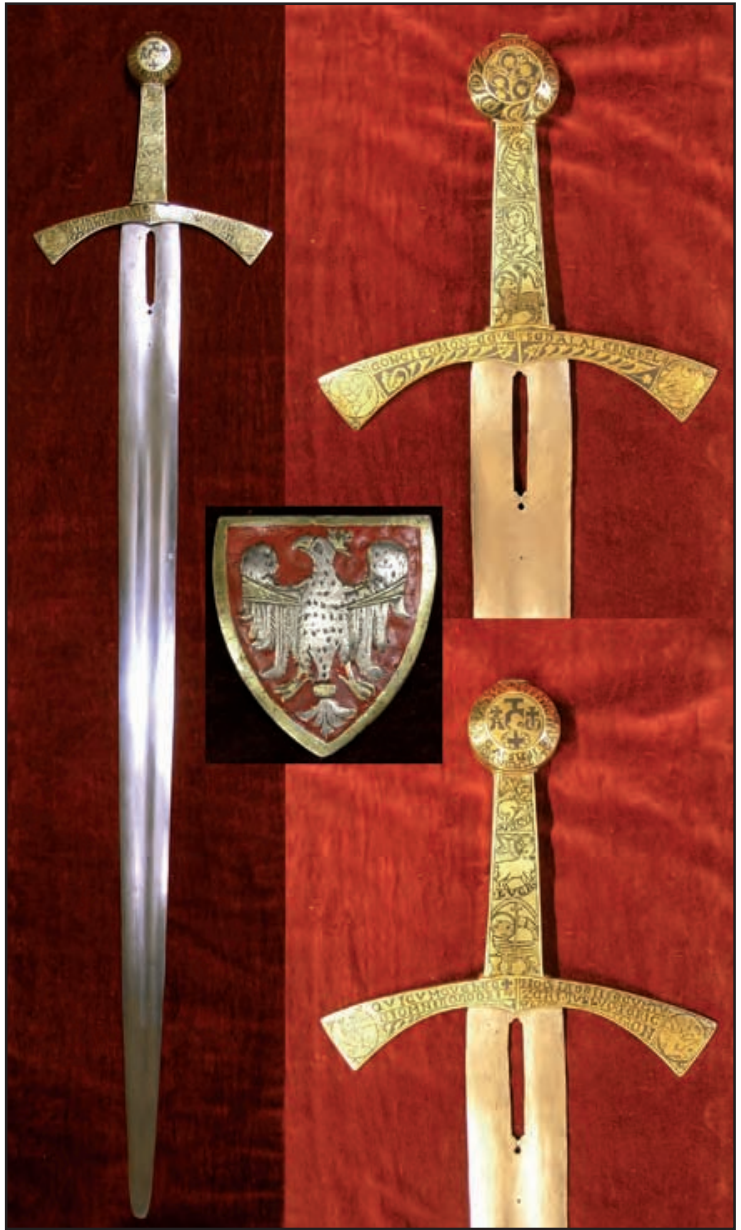

Figure 1. Szczerbiec, Royal Castle of Wawel, Kraków, Inv. No. 137. The 14th c. shield with Poland's coat-of-arms is now mounted on the blade through the rectangular slot in its upper part. It originally ornamented the scabbard. The shield was dismounted for the purpose of analyses. 
armour expert Prof. Zdzisław Żygulski jr (Żygulski 2008). It provided the members of the research team with numerous inspiring ideas.

The authors are indebted to the following scholars for their kind assistance and consultation: Prof. Jan Ostrowski, Director of the Royal Castle of Wawel in Kraków, Jerzy T. Petrus, M.A., Vice-Director of the Royal Castle of Wawel in Kraków, Jan Kostecki, M.Sc., and Mr Piotr Galant (Conservation Lab of the Royal Castle of Wawel in Kraków), Mateusz Biborski, M.A. (Conservation Lab, Institute of Archaeology, Jagiellonian University in Kraków), Prof. Joseph Dan (Hebrew University of Jerusalem), Dr Gideon Bohak (Tel Aviv University), Dr Helen Nicholson (Cardiff University), Prof. Fernando Quesada Sanz (Universidad Autónoma de Madrid), Dr Alvaro Soler del Campo (Real Armería Madrid), Dr Alfred Geibig (Kunstsammlungen Veste Coburg), Dr Marc Gener de Miguel (Universitat Oberta de Catalunya), and Dr Tomasz Płóciennik (University of Warszawa). Special thanks go to Metalodlew SA (Kraków) for their financial support of the analyses and supplying the necessary equipment.

\section{THE LEGEND - THE HISTORY OF THE SWORD}

The name of the Szczerbiec appears for the first time in the so-called Chronicle of Great Poland (late $13^{\text {th }}$-early $14^{\text {th }} \mathrm{c}$. ?) in the story of Duke (and later King) Bolesław Chrobry (the Brave). The sword was told to have been given to the Duke by an angel and thanks to its Divine power Bolesław was able to triumph over his enemies. The name of the weapon (the Jagged Sword) is related to Bolesław's expedition to Kiev in 1018, when the Duke hit the stronghold's gate to commemorate his victory and jagged the blade of the sword. This source states that at the time when the chronicle was written the sword was kept in the treasury of the Kraków Cathedral (Chronica Poloniae Maioris 1970, c. 11: 16-18; see also Kopera 1904, 18-19; Kuczyński 1961, 563-565; Rożek 1987, 134; Lileyko 1987, 14, 16; Rokosz 1988, 10 14, 16; Rokosz 1994, 215-218; Dalewski 1996, 131; Plezia 1996, 198; Ławrynowicz 2005, 40; Chodyński 2007, 192; Żygulski 2008, 313). The episode with striking at the gate with the sword is mentioned in earlier sources as well, concerning the Kiev expeditions of both Bolesław Chrobry in 1018 and Bolesław Śmiały (the Bold) in 1069) (e.g., a chronicle of socalled Gallus from the early $12^{\text {th }}$ c., Anonymous 1952, I.7: 22-23, I.23: 48-49; an early $13^{\text {th }}$ c. chronicle of Wincenty called Kadłubek, II.12, 3: 42, II.18, 2: 52; see also Gumowski 1959; 6; Żygulski 1975, 89; Rokosz 1988, 8-10; Rokosz 1994, 212-213; Plezia 1996, 196-197) but no name of the sword was given.

The mention of the sword being stored in Kraków is of interest. The Vita of St Stanisław (mid-13 $3^{\text {th }}$ c.) states that Polish coronation insignia, received by Duke Bolesław Chrobry in 1000 from Emperor Otto III, were kept in the Kraków Cathedral treasury. This source mentions, however, the crown, the sceptre and the lance (the copy of the St Maurice's Lance) only (Vita Sancti Stanislai 1884, 365-366, 399; see also Rożek 1987, 37-38; Rokosz 1988, 14; Rokosz 1994, 209-210). Significantly, the Chronicle of Great Poland also mentions the convention of Bolesław with Otto in 1000 and the Imperial gift of the crown and the lance. On the other hand, no mention of storing the insignia in Kraków is given (Chronica Poloniae Maioris 1970, c. 11: 16-18).

So-called Annals of Little Poland (late $13^{\text {th }}$-early $14^{\text {th }}$ c.) mention the fact of striking at the gate of Kiev by Bolesław Chrobry, but without stating the name of the sword (Rocznik matopolski 1878, 142-143). The same is notable in the mid-15 ${ }^{\text {th }} \mathrm{c}$. chronicle of Jan Dhugosz, both concerning Bolesław Chrobry and Bolesław Śmiały (Długosz 1964, Lib. 2, 261, 280-281; see also Plezia 1996, 199; Długosz 1970, Lib. 3, 100-105, 118-120; see also Plezia 1996, 200). 
When describing the royal coronation of Władysław Łokietek in 1320 in Kraków, Długosz mentions the royal insignia - the crown, the orb, the sceptre and other, which were transported from Gniezno (one of Poland's first capitals) at that occasion. The sword is not explicitly mentioned (Długosz 1978, Lib. 9, 107-109; Rożek 1987, 134-135). The coronation sword (without a name!) is first mentioned by Długosz under 1370 (Długosz 1985, Lib. 10, 24-25; see also Żygulski 1975, 89; Rożek 1987, 49-50; Rokosz 1988, 18-19; Rokosz 1994, 219; Chodyński 2007, 192; Żygulski 2008, 310) and the name Szczerbiec appears for the first time under 1412 (Długosz 1877, Lib. 11-12, 145-146; see also Żygulski 1975, 89; Rożek 1987, 4950; Rokosz 1988, 18-19; Rokosz 1994, 219; Chodyński 2007, 192). Significantly, a sermon by Stanisław of Skalbmierz from 1413 mentioned the Szczerbiec, referred to as the weapon of King Bolesław, together with the Polish royal crown (Rokosz 1994, 220). For the first time the sword with its name Szczerbiec was mentioned by Długosz in a coronation context under 1447, at the occasion of the coronation of Kazimierz the Jagiellonian (Długosz 1878, Lib. 12(13), 32-33; Rożek 1987, 135; Dalewski 2007, 96; Żygulski 2008, 310).

Based on the mentions by Długosz, it is supposed that the Szczerbiec was first used as a coronation sword by Władysław in 1320 (e.g., Rożek 1987, 48, 74, 135; Dalewski 1996, 131-132; Ławrynowicz 2005, 71, 110). It is certain, on the other hand, that other insignia used by Władysław in 1320 were not transported from Gniezno. The first Polish coronation insignia (save the Lance), used by Bolesław Chrobry in 1025, were taken in 1036 to Germany by Queen Rycheza, the widow of his son Mieszko II. New ones were made for the coronation of Bolesław the Bold in 1076, and it was them that were mentioned by the Vita of St Stanisław in the mid-13 ${ }^{\text {th }}$ c. (Rożek 1987, 35-38; Rokosz 1994, 209-210). It cannot be excluded that a sword was also present among them. This is assumed based on the Polish coronation rite, which derived from the $10^{\text {th }}$ c. Pontificale Romano-Germanicum. It mentions the use of a sword (see Nowacki 1997, 146-149; Dalewski 2007, 93-94; Dalewski 1996, 130131; Ławrynowicz 2005, 68-70). That sword was, however, perhaps taken together with other insignia (those of Bolesław the Bold, but without the Lance) in 1290 by Duke Przemysł II, when he had to retreat from Kraków facing the invasion of King Vaclav II of Bohemia. The insignia were used by Przemysł II for his royal coronation in 1295 in Gniezno. After his death in 1296 the insignia remained in Gniezno and they were used again in 1300 for the coronation of Vaclav II for the King of Poland in 1300. Thereafter, they were taken by Vaclav to Bohemia and thus lost forever (Annales Poloniae Maioris 1962, 53; Petri Zittaviensis Cronica 1884, c. 50; Kopera 1904, 19-22; Gumowski 1959, 8; Rożek 1987, 40, 47; Lileyko 1987, 14-18; Rokosz 1994, 210; Nowacki 1997, 131, 150; Barański 2003, 37-38; Świeżawski 2006, 134 135; contra Ławrynowicz 2005, 71, 110). Władysław was therefore compelled to have new insignia made for his coronation in 1320 . The story by Długosz was meant to add a splendour of antiquity to Władysław's insignia and relate them to Great Poland and Gniezno, the first coronation site of the Kings of Poland (Rożek 1987, 47, 77-78; Rokosz 1988, 16; Rokosz 1994, 211, 218-219; Żygulski 2008, 313).

It is therefore possible that the tradition of the Szczerbiec as a Heavenly gift for Bolesław Chrobry, the first King of Poland, was already shaped in the times of Władysław Łokietek. As mentioned, the date of origin of the Chronicle of Great Poland is not precise. Although the Chronicle states that it was written during the reign of King Przemysł II (1295-1296) (Chronica Poloniae Maioris 1970, 3), there are strong premises that some fragments, in particular those related to the Szczerbiec, were eventually codified in the first part of the $14^{\text {th }} \mathrm{c}$. (Kuczyński 1961, 563-565; Rożek 1987, 134; Rokosz 1988, 16; Rokosz 1994, 215-216; an introduction by B. Kürbis in Chronica Poloniae Maioris 1970, VII-VIII). It cannot be excluded that the $14^{\text {th }}$ c. version of the story of Szczerbiec purposefully created a hybrid of «the sword-the insignia» 
by stating that the sword was stored in the Kraków Cathedral Treasury. This was done in order to relate the sword to King Bolesław and to justify its use during the coronation of Władysław in 1320 (cf. Kuczyński 1961, 563-565). As it is discussed below, the Szczerbiec is a weapon of fairly $13^{\text {th }}$ c. features; moreover, it bears numerous atypical traits. As Władysław Łokietek had his other insignia made, a question may be asked why he did not order a new coronation sword to be made. It seems that there must have been a particular political reason for using the Szczerbiec, the sword he perhaps inherited from an earlier Polish duke. The issue of what that political reason was and from whom Władysław may have inherited the sword is of crucial significance for tracing the origin of the weapon.

Since 1475 the Szczerbiec was frequently mentioned in the inventories of the Royal Treasury in Kraków (Hubert 1861, 128-130; Smolikowski 1879, 31-32; Kopera 1904, 36-37; Spieralski 1974, 24-25; Rożek 1987, 78-79, 81; Żygulski 2008, 314). Some of the records state that the sword was associated with King Bolesław, although both Bolesław Chrobry and Bolesław Śmiały were mentioned (the record from 1589, see Kopera 1904, 83, 87, 149; the record from 1632, see Niemcewicz 1839, 49, Kopera 1094, 161-162, Spieralski 1974, 25-26, 1974, Rożek 1987, 82-83 and Żygulski 2008, 314; the record from 1669, see Hubert 1861, 149-151, Smolikowski 1879, 31, Kopera 1904, 182, Spieralski 1975, 27, and Rożek 1987, 85; the record from 1676, see Niemcewicz 1839, 52, and Rożek 1987, 86). The inventories also make clear that the sword was not always stored in proper conditions. In 1737 it was recorded that the Szczerbiec was thoroughly cleaned and a new scabbard was made, because the old one was completely corroded (Kraszewski 1879, 6; Sadowski 1894, 73-74, 76-77; contra Lileyko 1987, 72; Rożek 1987, 135; Żygulski 2008, 317; for the $15^{\text {th }}$ the $18^{\text {th }} \mathrm{C}$. history of the sword see also Kopera 1904, 31-34; Żygulski 1975, 89; Rożek 1987, 49-50; Rokosz 1988, 18-19; Rokosz 1994, 219; Chodyński 2007, 192; Żygulski 2008, 310-317). The record from 1737 is especially significant, as its sheds light on the issue of the rectangular slot in the upper part of the blade.

In 1764, on the eve of the coronation of Stanisław August Poniatowski, the last King of Poland, a pictorial documentation of the coronation insignia was prepared by Johann Christoph Werner.

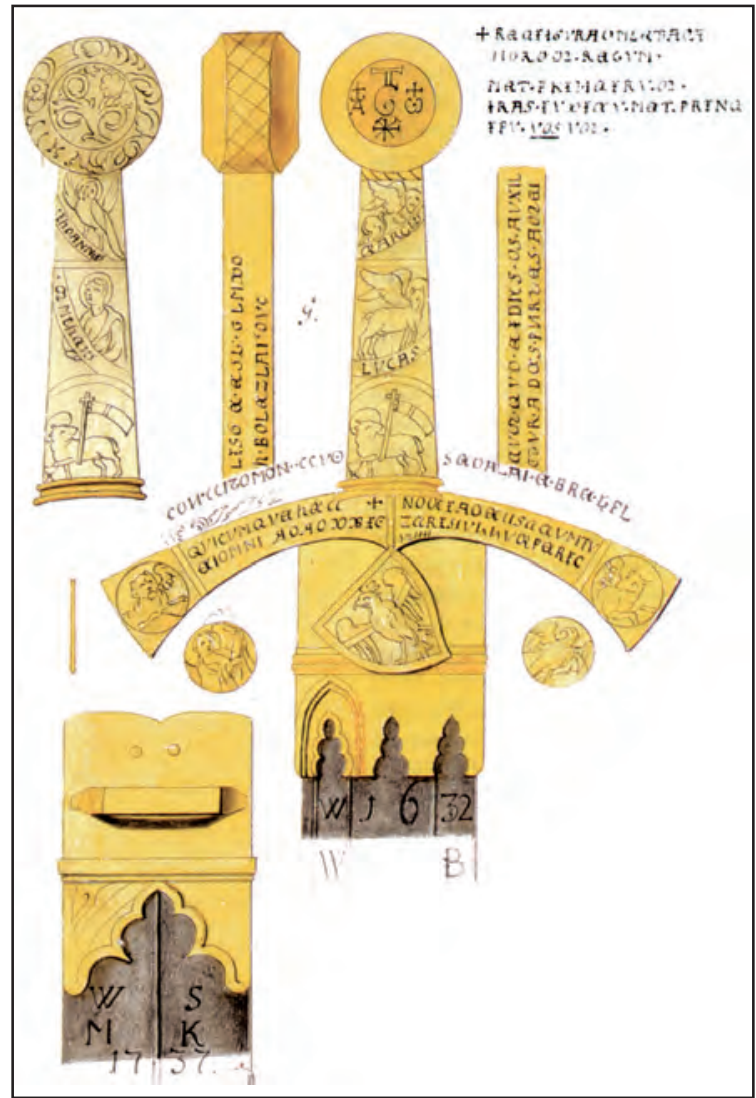

Figure 2. Drawing of the Szczerbiec by Johann Christoph Werner (1764). After Kossecka 1999, 243, fig. 223.

His drawings (see fig. 2), being the oldest preserved image of the Szczerbiec, offer a very faithful representation of the sword, save some minor mistakes and simplifications. The sca- 
bbard is not medieval but a new one, made in 1737 according to a Gothic pattern. As it can be seen, the shield with the coat of arms is mounted on the scabbard's mouth. Furthermore, the drawing by Werner depicts the narrow side plates of the grip (non-existent now), with the name of a Duke Bolesław (Sadowski 1894, 76-77; Lileyko 1987, 72; Nadolski 1992, 219-223; Chodyński 2007, 192; Wątroba 2007, 194; Żygulski 2008, 316-317).

In 1792 the last inspection of the

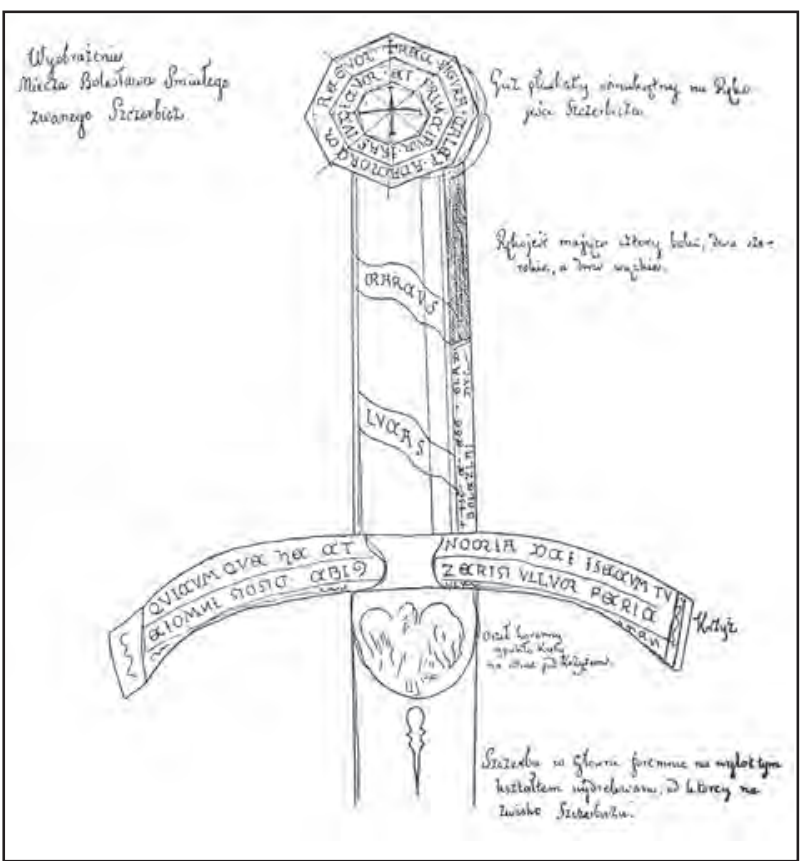

Figure 3. Drawing of the Szczerbiec by Rev. Jacek Przybylski (1792). After Radzikowski 1898, 11, fig. 1.
Royal Treasury before the partitions of Poland was carried out. Rev. Jacek Przybylski drew an image and thoroughly described the Szczerbiec, considered to have belonged to King Bolesław Śmiały (see fig. 3). He faithfully copied the inscriptions on the hilt, including the two on the narrow side plates. Most significantly, he mentioned that part of the plate bearing the inscription with the name of Duke Bolesław was damaged and covered with a silver plaque. The inscription was therefore only partially legible. His drawing, on the contrary, was an extremely schematic one. On the other hand, this drawing first depicts the hole in the upper part of the blade. As Rev. Przybylski said, the gap (szczerba in Polish) was drilled through into a regular shape, and it gave the name of the Szczerbiec to the sword. In fact, the hole on the drawing has an irregular shape and significantly broadens towards the crosspiece. Regrettably, it cannot be said to what extent Rev. Przybylski's drawing is trustworthy with regard to that (Radzikowski 1898, 11, fig. I, 13, fig. II; Sadowski 1894, 78-82; Żygulski 1975, 89; Rożek 1987, 95, fig. 69-70; Nadolski 1992, 219-223; Żygulski 2008, 317-319).

In 1795 the Royal Treasury was thoroughly robbed by Prussians and in all probability the Szczerbiec was taken away by them together with other insignia. No information on the fate of the sword until 1819 has come to light so far (Sadowski 1894, 62; Żygulski 1975, 89; Rożek 1987, 97-101; Chodyński 2007, 192; Żygulski 2008, 319). In 1819 Prince Dimitri LabanovRostovsky, the Minister of Justice of the Russian government, offered the sword for sale to the Polish General Wincenty Krasiński. According to Prince Labanov, the sword was bought from an Armenian merchant, who found the sword in a ditch between Belgrade and Ruščuk (now Ruse in Bulgaria) during the Serbian campaign of 1811-1812. This story (repeated in the afore-mentioned works of Laking and Oakeshott) was certainly untrustworthy, and Prince Labanov probably bought the sword in 1811 from a Prussian official in Berlin or Königsberg (now Kaliningrad in Russia), as in that year Polish coronation insignia were melted down in Königsberg. He could not give a true story of the sword, as the Russian Emperor Alexander I also held the title of the King of Poland at that time, and revealing the fact of the Polish insignia having been destroyed by Prussians could negatively impact the political relations 
between Russia and Prussia. General Krasiński eventually did not purchase the sword, but a lithography of the weapon was prepared upon his request (see figs. $4 \mathrm{a}$ and b). Based on this, an analysis of the weapon was carried out by Professor Samuel Ciampi, a scholar from the University of Warszawa (see Sadowski 1894, 64-66; Żygulski 1975, 89; Lileyko 1987,73; Rożek 1987, 137-138; Chodyński 2007, 192; Żygulski 2008; 319, 321).

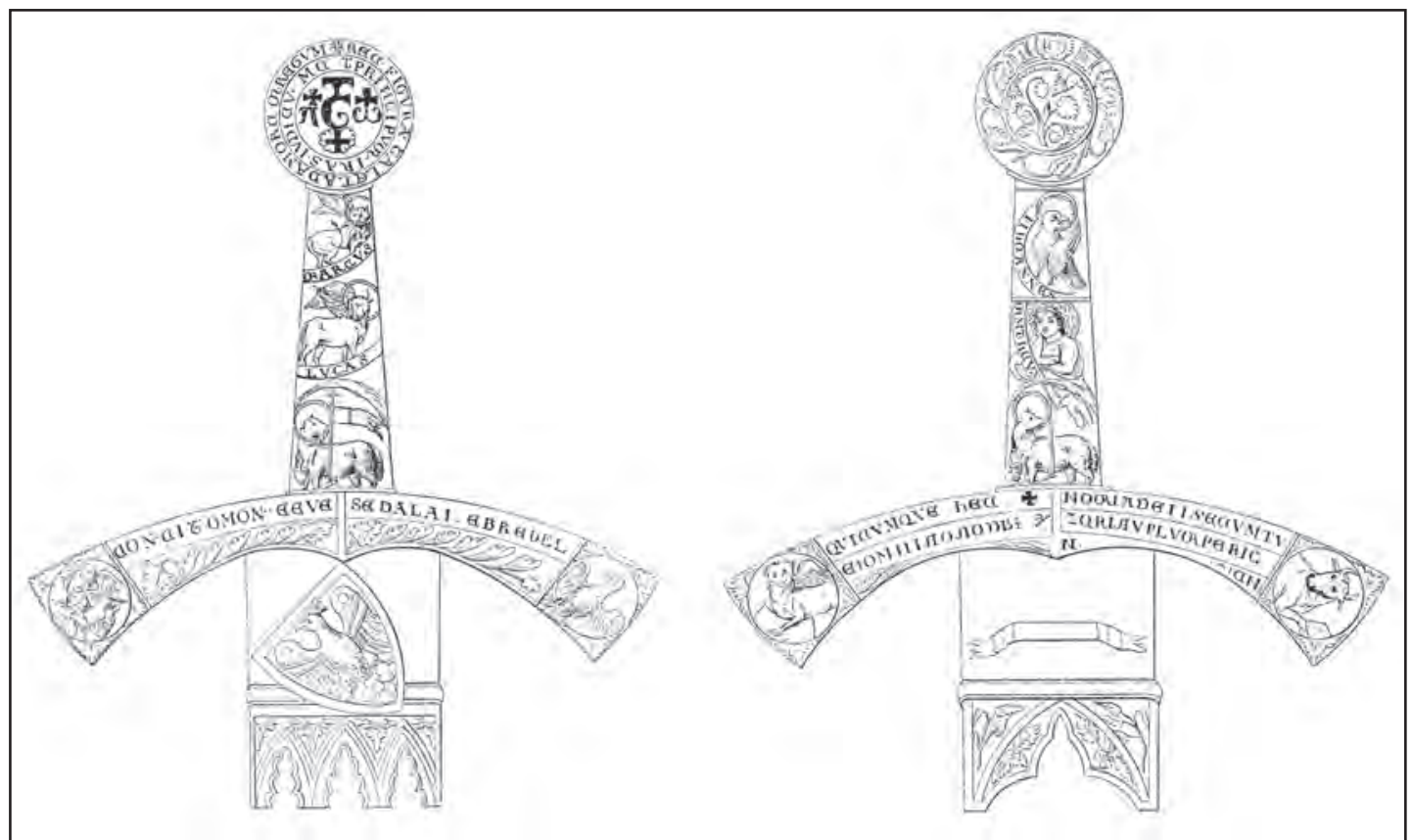

Figure 4a. Drawing of the Szczerbiec from 1819. After Sadowski 1894, 66-67, figs. I and II.

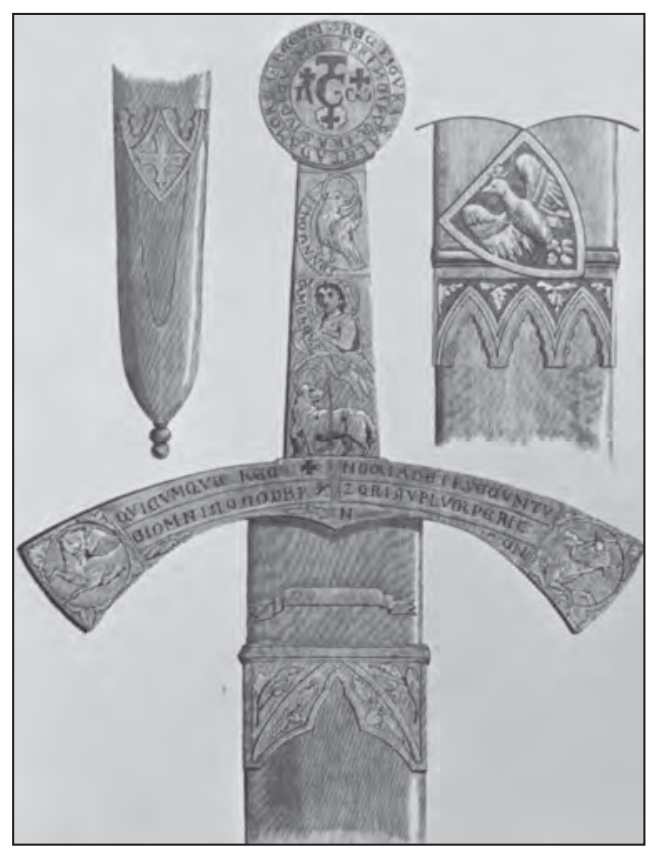

The images Ciampi was provided with were in general quite trustworthy, as compared to the drawing by Werner from 1764. Ciampi, however, made several serious mistakes when reading the inscriptions. Furthermore, he did not offer an interpretation of all the symbols of the sword pommel. Interestingly, he did not mention the inscribed narrow side plates of the grip. This suggests that they got lost between 1795 and 1819. In conclusion, Ciampi stated that the sword may have belonged to a member of a military order (perhaps even a Polish knight), but did not consider the sword to be the Polish coronation weapon (Ciampi 1819, 3-10; see also Sadowski 1894, 64-65; Żygulski 1975, 89; Lileyko 1987, 73-74; Żygulski 2008, 321-322).

Figure $4 b$. Lithography of the Szczerbiec from 1819. After Lileyko 1987, 77, fig. 64. 
Of considerable interest is the issue of the shield with the coat of arms and the scabbard. In the drawing by Rev. Przybylski from 1792 the shield seems to be somewhat mounted on the blade; on the other hand, the credibility of his drawing is far from satisfactory. As it can be seen on the images from 1819 the shield is still mounted on the scabbard and the scabbard itself seems to be the same as that drawn by Werner in 1764 (see also Sadowski 1894, 73-76; Nadolski 1968, 113).

After General Krasiński had turned down the purchase offer, Prince Labanov sold the sword (before 1843) to a Russian antiquary Prince Nikolai Demidov in San Donato near Florence. In 1870, after the death of his son Anatol, the sword went to another Russian antiquary Anatoly P. Bazylevsky, who had the sword thoroughly «restored.» In 1878 the sword appeared on display at the World Exhibition in Trocadero near Paris (Sadowski 1894, 68-71; Gumowski 1959, 17-18; Żygulski 1975, 89; Lileyko 1987, 74; Rożek 1987, 139; Chodyński 2007, 192; Żygulski 2008, 323).

At that time the Szczerbiec was provided with several new features. As it can be seen on the image from 1870 (see fig. 5), the slot in the upper part of the blade was covered with ornamented plates. A new scabbard was made and the shield with the coat of arms was surrounded with an inscription + HIC GLADIVS EST FORTISSIMI MILITIS XPI SICVT GLADIVS SAVLIS. Images and descriptions from 1878 demonstrate new changes, done upon the request of $\mathrm{A}$. Bazylevsky. Ornamented plates in the upper part of the blade were replaced with new narrow ones. One of

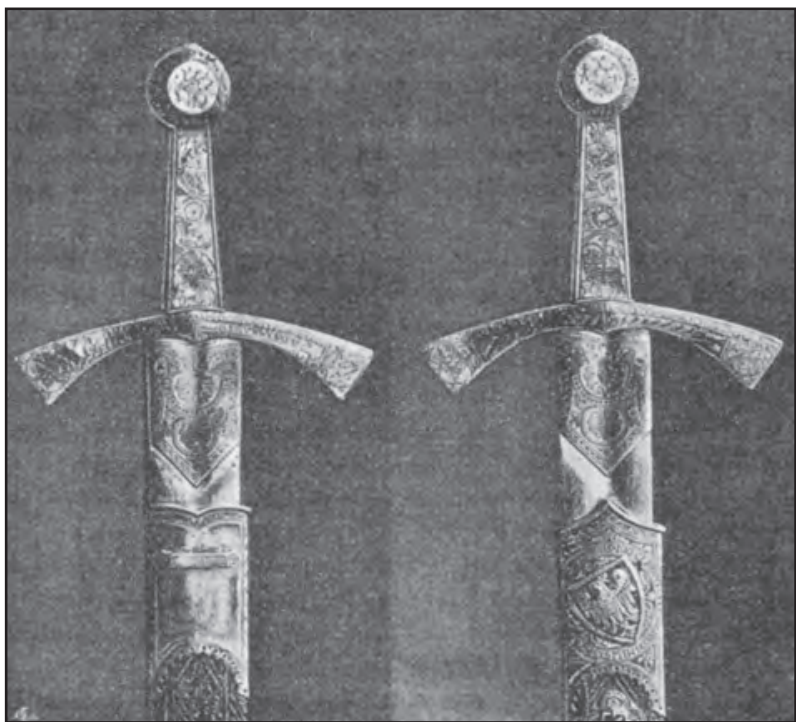

Figure 5. Szczerbiec in 1870. After Sadowski 1894, 87, fig. 5. them was provided with the same inscription as the one around the shield. The other one bore another inscription ISTE EST GLADIVS QUO IVDAS CASTRA FILIORVM ISRAEL PROTEGEBAT (see figs. 6 and 7). The former inscription is a paraphrase and the other a quotation from the early $14^{\text {th }} \mathrm{C}$. Teutonic chronicle by Peter of Dusburg (see Petri de Dusburg Chronicon 1861, P. II, C. 8: 41). They reflect $19^{\text {th }}$ c. opinions that the sword may have been related either to Knights Templar or to the Teutonic Order (Beaumont 1878, 710; Smolikowski 1879, 18, 20-21; Sadowski 1894, 84-89, 108-109, - although Sadowski fully accepted the opinion of the Teutonic origin of the sword, he considered the weapon for the authentic Polish coronation sword; Gumowski 1959, 11-12, 17; Kuczyński 1961, 566; Żygulski 1975, 89; Lileyko 1987, 74; Rożek 1987, 138; Chodyński 2007, 192; Żygulski 2008, 323). A relation of the Szczerbiec to the Teutonic Order was also assumed by G. Laking (Laking 1920, fig. 123, 101-103), and repeated by E. Oakeshott (Oakeshott 2002, 41).

In 1884 the sword was purchased to the Hermitage in St Petersburg, but Russian specialists considered it as the so-called Radziwiłł replica from the $17^{\text {th }}$ c. (Lenc 1908, 275-276). The Szczerbiec returned to Poland in 1924, but in 1939 it was evacuated to France, Britain and eventually to Canada. It finally returned to Poland in 1959 (Gumowski 1959, 18; Rożek 


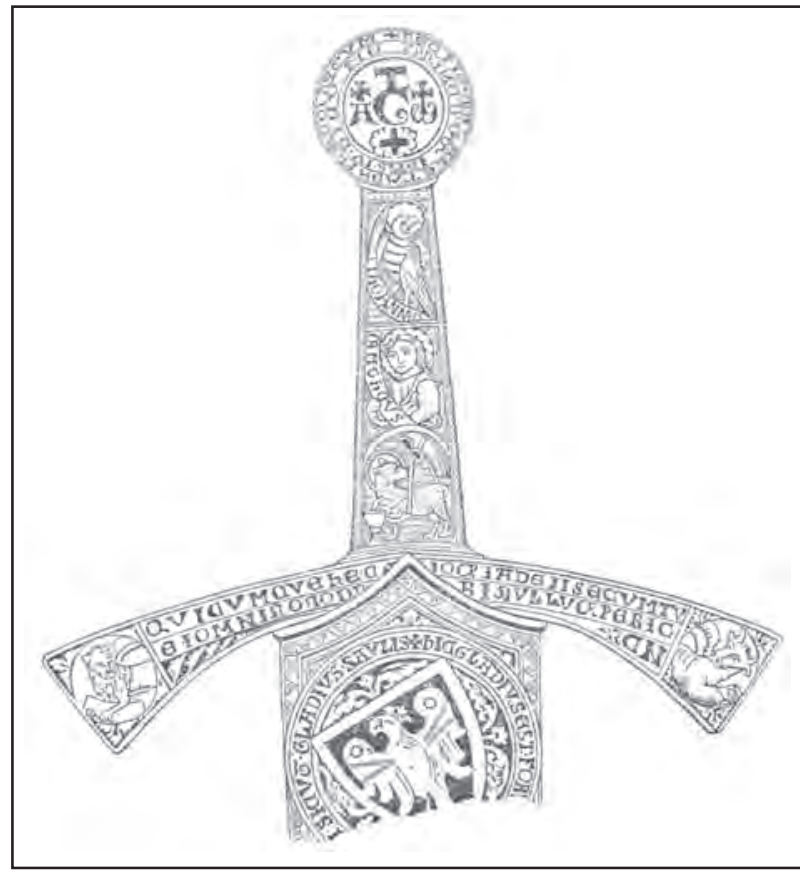

Figure 6. Szczerbiec in 1878. After Sadowski 1894, 72, fig. 4 .

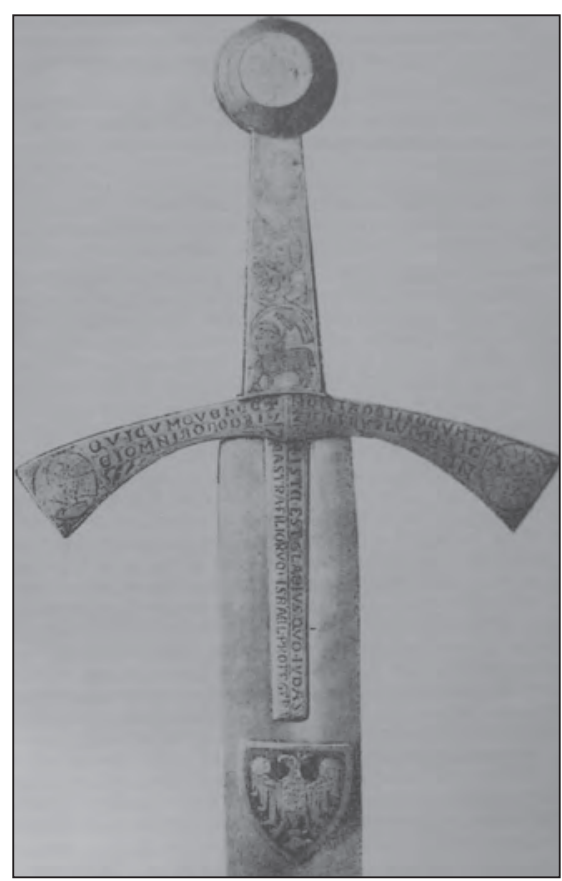

Figure 7. Szczerbiec in 1878. After Semkowicz 2002, 501, fig. 177.

1987, 138-139; Lileyko 1987, 74; Żygulski 1975, 90; Chodyński 2007, 192; Żygulski 2008, 326, 332-339).

The complex and not always clear history of the sword in the $19^{\text {th }} \mathrm{c}$. gave rise to some doubts concerning its authenticity as the Polish coronation sword. It is known that in the $17^{\text {th }}$ c. a replica of the Szczerbiec was made upon request of Jan III Sobieski King of Poland (16741696). It later went into the hands of the Radziwiłł Princes and was described in the inventory of their treasury in Nieśwież in 1740. In 1812 it was confiscated by Russian troops. Some scholars therefore suggested that the weapon exhibited in Trocadero may have in fact been the Radziwilł replica (see Żygulski 1975, 91-92). This assumption may to a degree be discarded by differences between the Wawel sword and the Radziwiłł replica (for the description from 1740 see Łepkowski 1881, 2-3; see also Sadowski 1894, 112-113; Rożek 1987, 137, 140; Lileyko 1987, 74-76; Żygulski 2008, 315). It is known, on the other hand, that the sword exhibited in Trocadero drew the attention of contemporary forgers (Nadolski 1992, 219-223, points to a drawing by a famous collector and forger Mariano Fortuny, which depicts an extremely similar weapon). The only way to clarify this issue were technological analyses of the Wawel sword.

\section{TECHNOLOGICAL ANALYSES}

Due to the significance of the Szczerbiec, all technological analyses had to be carried out by non-destructive methods. No sampling was therefore possible; instead, surface polishing was applied. The analyses had the following aims:

- defining the blade manufacturing technology, based on metallographical, X-ray and flaw detection examinations 
- defining the chemical composition of the metal of the hilt

- traseological examinations of the hilt

\section{THE BLADE}

\section{Metallographical Examinations}

Observations of the blade microstructure were carried out with a Leica - DMLM optical microscope, in two spots (marked as A and B) on the flat near the crosspiece (see fig. 8). Spot A was located c. $4 \mathrm{~cm}$ below the crosspiece, near the rectangular slot in the blade, while Spot $\mathrm{B}$ was located c. $14 \mathrm{~cm}$ below the crosspiece. For the purpose of microscopic examinations the blade surface was polished with diamond pastes and then etched with $4 \%$ Nital regent (a solution of nitric acid in alcohol) in order to reveal the microstructure.

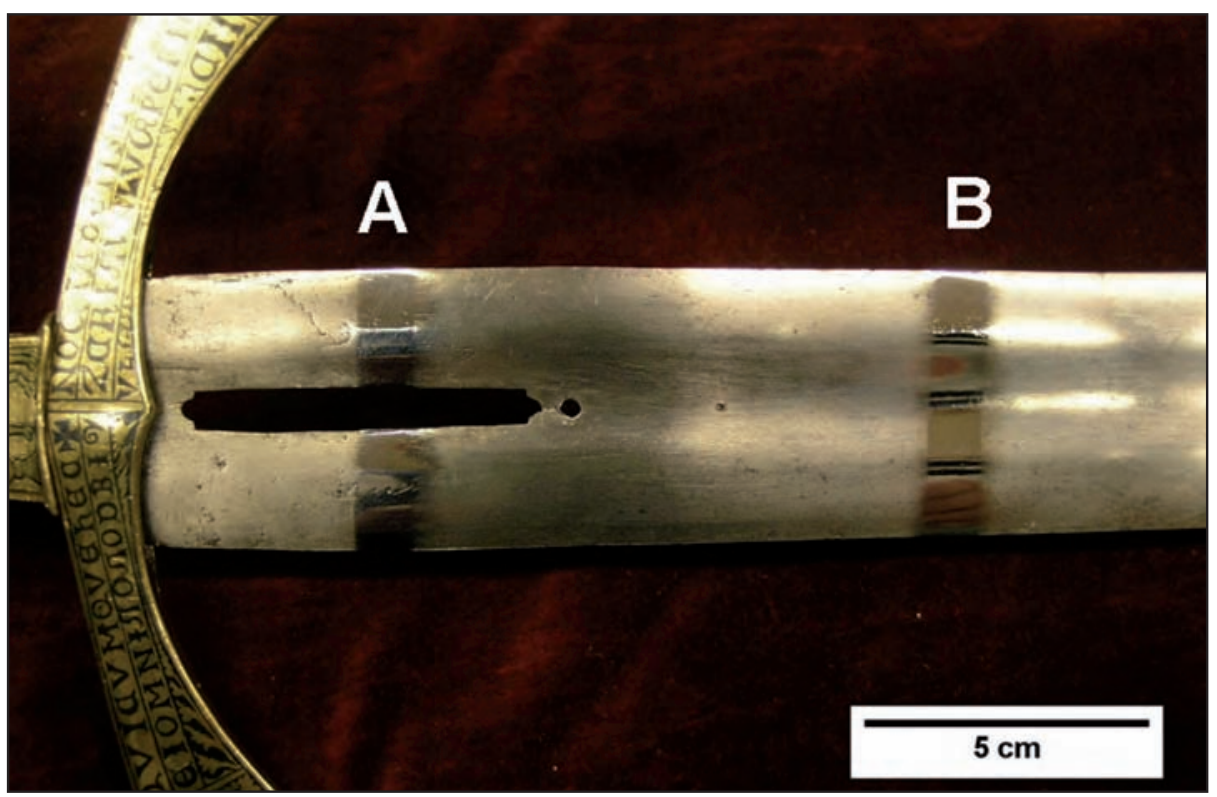

Figure 8. Spots of metallographical examinations of the blade.

\section{Observations of the Microstructure in Spot A}

The dominant microstructure in Spot A corresponded to the initial material for blade manufacture, i.e., semi-hard steel with c. $0.3-0.5 \% \mathrm{C}$ contents (fig. 9). It locally changed, however, from ferritic-pearlitic, which corresponds to soft steel with c. $0.1-0.2 \% \mathrm{C}$ contents (fig. 10), to pearlitic-ferritic one, which corresponds to hard steel with c. $0.5-0.7 \% \mathrm{C}$ contents (fig. 11). In ferritic-pearlitic areas there were bands of ferrite of various grain size, perhaps phosphorusenriched (fig. 12); numerous oblong slag inclusions were also notable (fig. 13). No traces of thermal treatment were detected in the microstructure in Spot A.

\section{Observations of the Microstructure in Spot B}

Microstructure in Spot B - the presence of tempered martensite - pointed out that the farther part of the blade underwent thermal treatment, i.e., quenching and tempering (figs. 14 and 15). As in Spot A, numerous slag inclusions are notable here (fig. 16). 

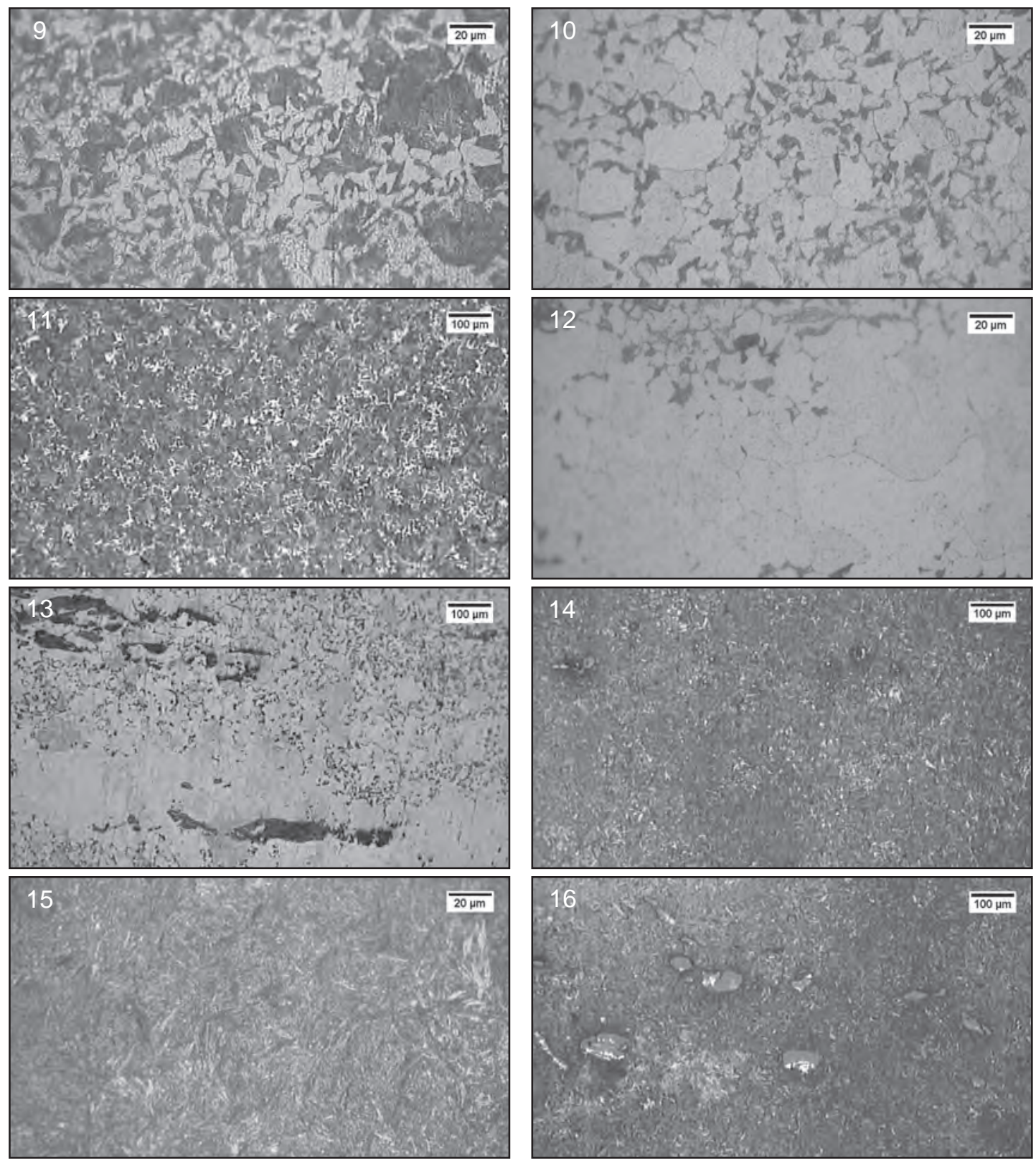

Figure 9. Area of medium carbon contents $(0.3-0.5 \% \mathrm{C})$ in Spot A on the surface of the flat of the blade. The microstructure consists of pearlite (dark phase) and ferrite (bright phase).

Figure 10. Area of low carbon contents $(0.1-0.2 \% \mathrm{C})$ in Spot A on the surface of the flat of the blade. The microstructure consists of ferrite (bright phase) and a small amount of pearlite (dark phase).

Figure 11. Area with higher carbon contents $(0.5-0.7 \% \mathrm{C})$ in Spot A on the surface of the flat of the blade. The microstructure consists of pearlite (dark phase) and a small amount of ferrite (bright phase).

Figure 12. Fragment of the microstructure of a ferrite band with various grain size. Spot A on the surface of the flat of the blade, the low carbon contents area.

Figure 13. Examples of morphology of slag inclusions in Spot A on the surface of the flat of the blade. Figure 14. General view of the microstructure on the surface of the flat of the blade in Spot B, which underwent thermal treatment - tempered martensite.

Figure 15. Microstructure of tempered martensite in a greater magnification.

Figure 16. Numerous slag inclusions in Spot B on the surface of the flat of the blade. 


\section{Discussion of the Analyses of the Blade Microstructure}

As it comes out from the observations of the microstructure in Spot A, the initial material for forming the blade was unevenly carburised semi-hard bloomery steel. It contained numerous slag inclusions, typical for contemporary iron smelting technology.

Particularly interesting data were provided by the microstructre in Spot B. It points out that the blade, which was forged from bloomery steel, underwent thermal treatment in order to harden its surface. This process usually consisted in heating the blade up to the red heat temperature (c. $830^{\circ} \mathrm{C}$ for the material with such carbon contents, see Pleiner 2006, 67-69; Tylecote and Gilmour 1986, 17-18; Wesołowski 1974, 269-311), immersing it in a quenching coolant (usually water or oil), and then in taking it out rapidly. Thanks to this the heat which was still present in the core of the blade tempered the surface, which was rapidly cooled and thus quenched. In this way a structure of tempered martensite was obtained - it is less hard that a purely martensitic structure, but it is more resistant to breaking and crumbling.

One more important information can be inferred from a comparison of the microstructures in Spots A and B. It was only part of the blade that was thermally treated. It cannot be excluded that the bladesmith purposefully applied such a manner of thermal treatment in order to prevent the blade from possible breaking near the hilt. It must be therefore concluded that the blade technology demonstrates a high level of competence of the bladesmith. The blade is of excellent functional quality with notable features of a weapon of war.

\section{$X$-ray Analyses}

The X-ray image had a more or less even contrast. Some minor spots, originating from external flaws (such as corrosion), were observed (fig. 17). They correspond to defects which are notable on the surface. They are caused by local discontinuities of the material and are typical for bloomery iron. They are very shallow and have no significant influence on the quality of the blade.

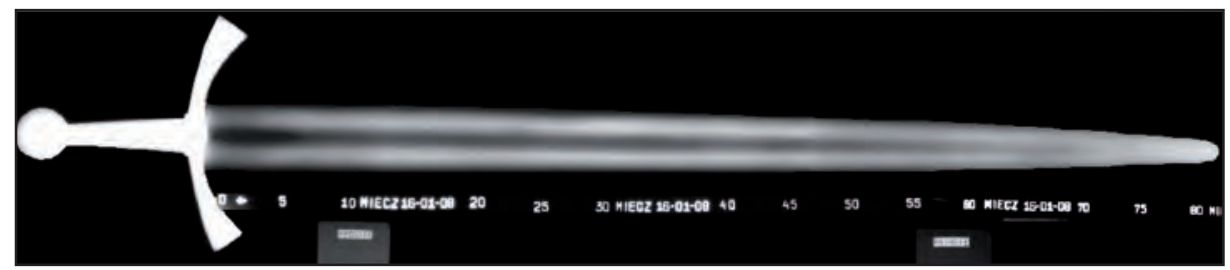

Figure 17. X-ray of the Szczerbiec.

\section{Flaw Detector Analyses}

As it was not possible to carry out a cross-section polishing of the blade, the flaw detector analyses aimed at addressing a question whether the blade was forged from one or more pieces of metal. The first analysis was carried out with a Krautkamer DME DL thickness meter with a $4 \mathrm{MHz}$ double converter head. The results suggested a material discontinuity in the middle of the thickness of the blade. This may imply that the blade was made from a piece of metal which was first hammered flat and then folded and forged again. Another result was obtained from an analysis with an USM ultrasonic flaw detector with a $15 \mathrm{MHz}$ and a delay line. This examination did not confirm the discontinuity; this may, however, result from the fact that the folds were forged very skillfully. Further technological analyses are planned to clarify this issue. 


\section{Chemical Composition Analyses}

The examination of the chemical contents was first aimed at identifying the existence of elements other than iron. The analysis was carried out with a FOUNDRY-MASTERS spark spectrometer in one single spot near the point of the blade. The results were the following:

\begin{tabular}{|c|c|}
\hline Element & $\begin{array}{c}\text { Contents } \\
\text { \% weight }\end{array}$ \\
\hline $\mathrm{C}$ & 0.6 \\
\hline $\mathrm{Mn}$ & 0.023 \\
\hline $\mathrm{P}$ & 0.092 \\
\hline $\mathrm{Si}$ & 0.153 \\
\hline $\mathrm{S}$ & 0.015 \\
\hline $\mathrm{Ni}$ & 0.044 \\
\hline $\mathrm{Al}$ & 0.029 \\
\hline $\mathrm{Cu}$ & 0.002 \\
\hline
\end{tabular}

This demonstrates that the blade was forged from bloomery steel with increased phosphorus contents. Increased contents of Si are perhaps related to numerous slag inclusions in the surface of the blade. The contents of other elements corresponds to those discovered in other bloomery iron items from the same period as the Szczerbiec.

\section{Traseological Examinations}

The aim of traseological examinations was to analyse the scope of destruction, which resulted from several hundred years of impact of corrosion and wear of the blade. This concerns traces of cleaning of the surface before each ceremonial use of the sword, as well as traces related to possible changes and damages, which were attempted at being restored. Especially significant is the issue whether the rectangular slot in the upper part of the blade resulted from corrosion or was made intentionally (figs. 1 and 8).

Attention is first of all drawn to the blade having been extensively cleaned by mechanical means, along its entire length. Deep scratches usually run in parallel to the blade length and they are well discernible with a binocular magnifying glass, already under c. $5 \mathrm{x}$ magnification (fig. 18a). Their depth and breadth suggests the use of thick grain abrasive, perhaps sand (or, as suggested by A. Nadolski, brick powder, see Nadolski 1968, 107). Such radical methods perhaps resulted from unfavourable storing conditions in the unheated treasury,

Figure 18. a. Scratches on the blade surface - remains of mechanical clearing. b. Inactive vestiges of corrosion on the blade surface with stabilised black patina. c. Traces of cleaning on some corrosion vestiges on the blade surface.
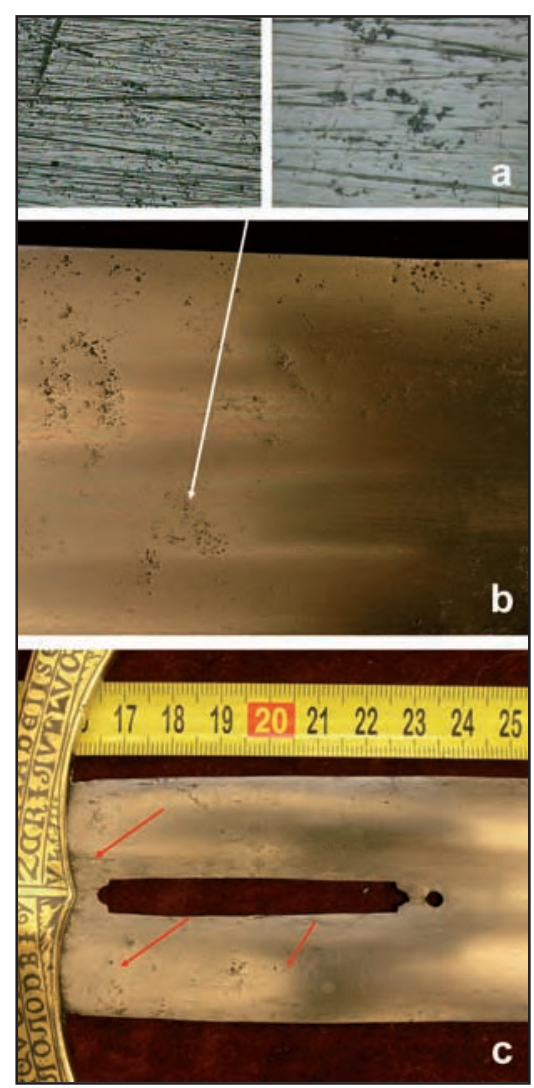
which steadily exposed the sword to corrosion. Remains of corrosion are notable in various spots on the entire surface of the flats on both sides of the blade. They are inactive now and are covered with stabilised black patina (fig. 18b). Traces of cleaning are still notable on some corrosion vestiges (fig. 18c). They were not cleaned due to the fact that the blade thickness is maximally $5 \mathrm{~mm}$ and only $1.2 \mathrm{~mm}$ near the point. Further cleaning and abrasion could lead to the blade losing the limit of its elasticity and possibly getting deformed.

There is a $64 \mathrm{~mm}$ long and $8.5 \mathrm{~mm}$ wide

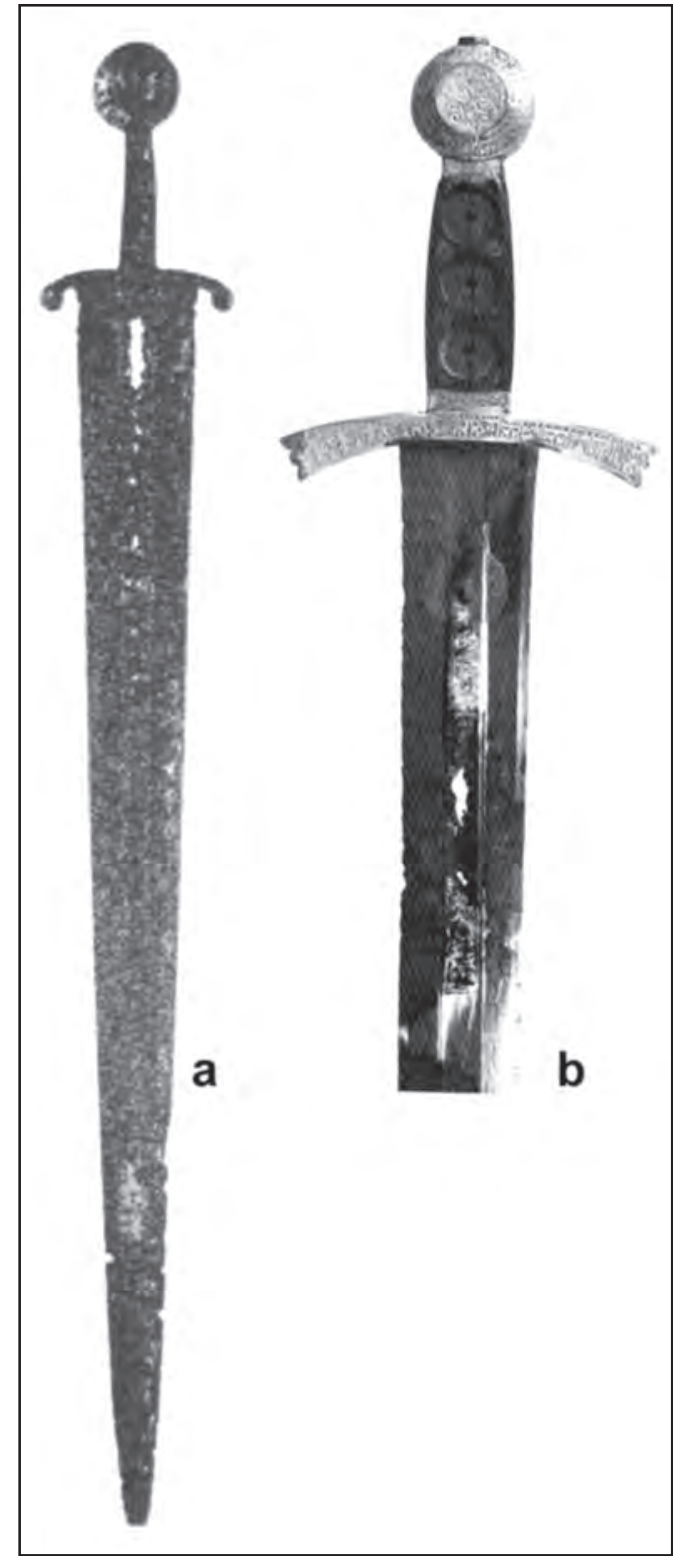

Figure 19. a. Sword from the Odeschalci Collection in Rome - Italy, c. 1450-1500. After di Carpegna 1969, 35, No. 200. b. Sword of King Sancho IV el Bravo of Castille and Léon (died 1298). After Oakeshott 2000a, 72. rectangular slot in the fuller in the upper part of the blade. Below that slot there are two round holes with their diameters being $28 \mathrm{~mm}$ and $1.4 \mathrm{~mm}$ respectively. They are located c. $24 \mathrm{~mm}$ from each other (see fig. 1). Their sides are not parallel to each other, which implies that they were not drilled but perhaps punched. Traces of flanges around the inlets suggest that the holes were punched in the $19^{\text {th }}$ c. in order to mount the shield with the coat of arms and the plates with inscriptions (see fig. 7). Had they been of earlier origin, the flanges would have become completely polished down in result of clearing of the blade for each ceremonial use.

Some controversy has been provoked by the nature of the rectangular slot. One needs to confirm the opinion by A. Nadolski, who considered the slot as having resulted from corrosion, and not as a vestige of a holy relic (Nadolski 1968, 112; contra Żygulski 2008, 353). This is supported by the existence of swords with similar damages, e.g., a c. 1450-1500 Italian sword from the Odescalchi Collection in Rome (di Carpegna 1969, 35, No. 200; see fig. 19a) and the sword of Sancho IV el Bravo of Castille and Léon (Oakeshott 2000a, 72; see fig. 19b). Most probably, in order to smoothen the perforation of irregular shape, a more or less regularly shaped slot was made with a file. This may be additionally confirmed by Rev. Przybylski's report from 1792, stating that the "gap» was drilled through into a regular shape (Radzikowski 1898, 11, fig. I, 13, fig. II).

\section{THE HILT}

\section{Technological and X-ray Analyses}

The first aim was to determine the kind of metal of the hilt. This issue was either omitted 
in previous scholarship or it was erroneously stated that the pommel and the crosspiece were made of gold-coveted iron (e.g., Nadolski 1968, 111). A simple magnet test demonstrated, however, that no ferrous elements were present save the tang.

It was found out that the crosspiece and the pommel were made of silver, most cast for cire perdue. This is implied by casting barbs, notable on the bottom side of the crosspiece and the circumference of the pommel, as well as by surfaces of free coagulation of metal, notable inside the pommel. This is based on macroscopic observations through a slot at the bottom of the pommel, with additional lightning of the inside of the pommel.

The pommel and the crosspiece are coveted with c. $1 \mathrm{~mm}$ thick plates of nielloed gold. This is particularly notable on the bottom edges of the crosspiece; furthermore, it is confirmed by a small perforation in the circumference of the pommel, through which its silver core can be seen (fig. 20). Nielloed ornaments and inscriptions were made by engraving the negatives with triangular and semiround-ended styles. This can be said based on sharp or rounded ends of the drawing lines. The negatives were filled with so-called hard substance of intensively black colour. Its chemical contents should be examined in future.

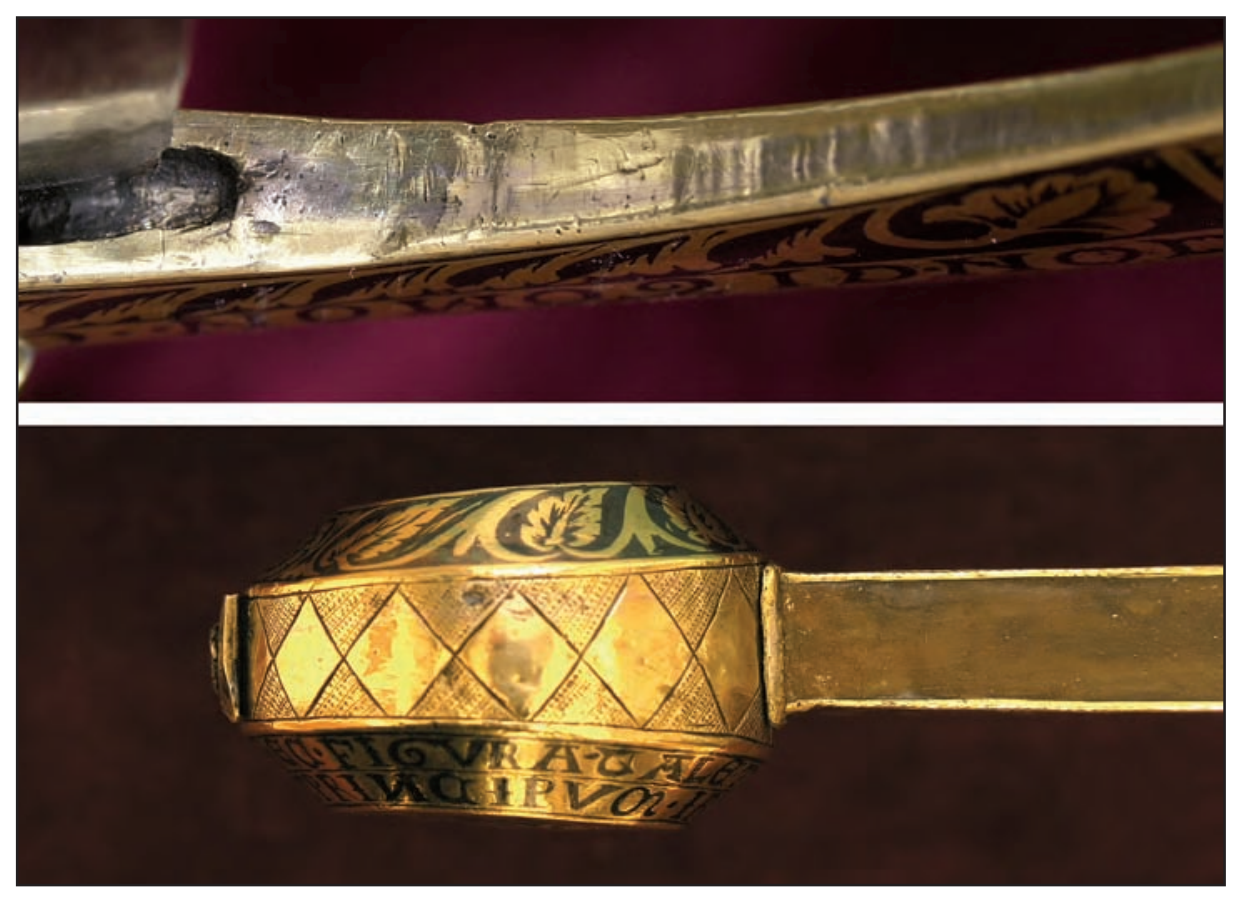

Figure 20. Perforation of the gold plate in the circumference of the pommel - the silver core can be seen.

The afore-mentioned parts of the hilt are ornamented with inscriptions and floral and figural representations. It is remarkable that the floral ornaments are gold against the black nielloed background, while the figural representations and inscriptions are nielloed against the gold background (fig. 1).

The core of the grip consists of a brass chest, put onto the tang (fig. 21). Gold nielloornamented front plates and one side plate, decorated with rhomboid ornament, are mounted on this chest. The side plate is a $19^{\text {th }}$ c. addition (see the images of the Szczerbiec from 


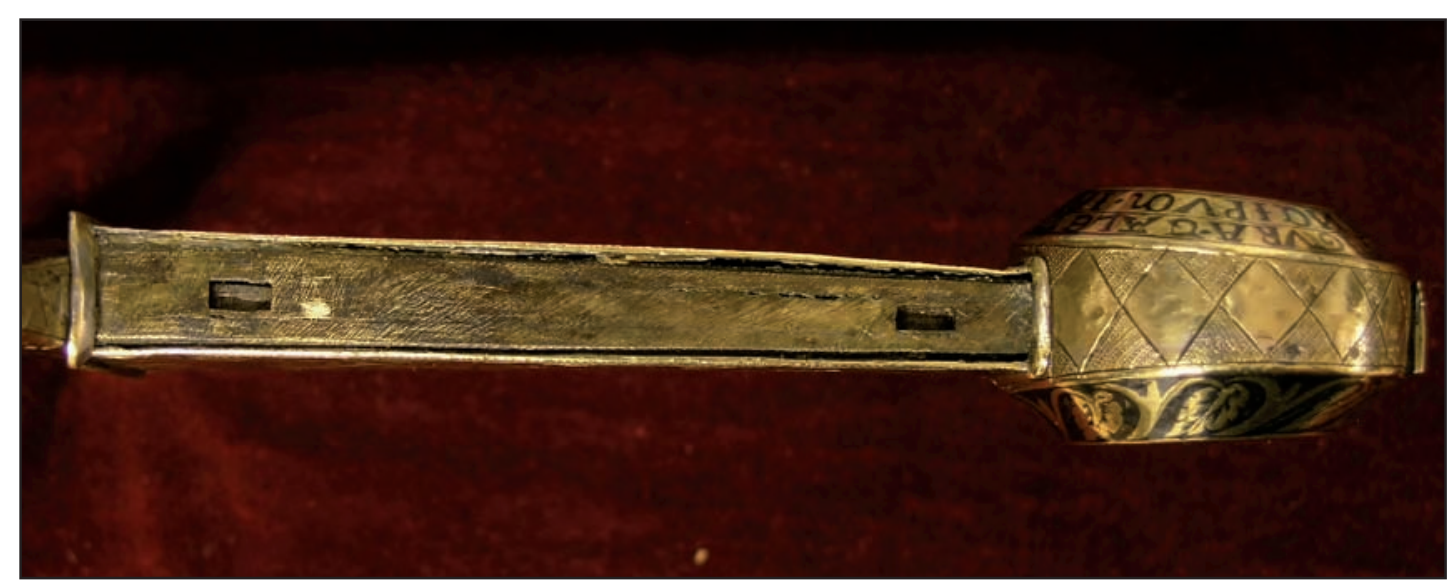

Figure 21. Core of the grip - a brass chest put onto the tang.

1764 and 1792, where both side plates are ornamented with inscriptions, Wątroba 2007, 195 and Rożek 1987, 95, fig. 69-70). This is additionally confirmed by traseological examination, which revealed traces of scratches done with a file of undoubtedly mass factory manufacture. The ornamented plates of the grip were in all probability mounted onto an organic core. This was due to functional reasons, i.e., a necessity of securing a stable mounting of the plates on the tang. Bearing in mind unfavourable storing conditions of the sword before 1792, it cannot be excluded that the organic core simply got rotten. Once again the drawings from 1764 and 1792 can be pointed out. They display a considerable notch on the plate with the name of Duke Bolesław. Such a notch perfectly facilitated a penetration of moisture into the grip. The rotten organic core was in all probability replaced with the brass chest. In order to put the chest onto the tang the entire hilt had to be dismounted. Repeated mounting of the hilt is confirmed by the end of the tang having been unprofessionally riveted on top of the tang and the addition of a washer below the rivet (fig. 22).

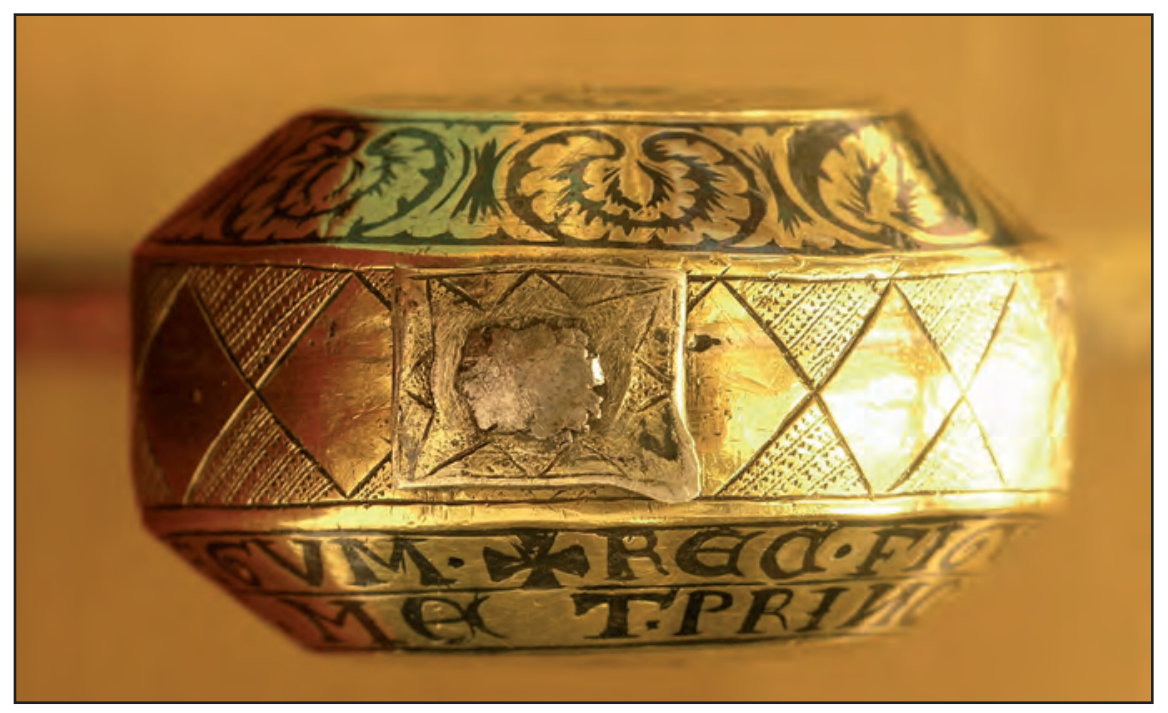

Figure 22. Repeated riveting of the tang and an added washer. 
Several X-ray photos of the hilt were aimed at revealing the shape of the tang and the way of mounting of the elements of the hilt. Initially, the exposure lasted 7 minutes at the tension of $120 \mathrm{kV}$. It was then repeated for 25 minutes at the tension of $180 \mathrm{kV}$. No satisfactory results, however, were arrived at. This resulted from a dispersion of X-ray due to considerable density and high atomic number of gold.

\section{Chemical composition analyses}

Due to impossibility of sampling, the analysis of the crosspiece was carried out with chrome liquid ( $3 \mathrm{~g}$ of $\mathrm{K}_{2} \mathrm{Cr}_{2} \mathrm{O}_{7} 3$ with an addition of $4 \mathrm{~cm}^{3}$ of $\mathrm{H}_{2} \mathrm{SO}_{4}$ and $32 \mathrm{~cm}^{3}$ of $\mathrm{H}_{2} \mathrm{O}$ ) in order to confirm the presence of silver. The liquid, put into a rubbed spot on the edge, rapidly assumed intensively dark red colour. This demonstrated the presence of silver, in all probability of high standard, being at least 0.800 . Furthermore, a spectrographic analysis of a small sample $\left(0.4 \mathrm{~mm}^{2}\right.$, c. $20 \mu \mathrm{m}$ thick) taken from the bottom side of one of the front plates of the grip, demonstrated that it was made of gold alloy, with $73.7 \% \mathrm{Au}, 18.8 \% \mathrm{Ag}$ and $6.5 \% \mathrm{Cu}$. Such a composition imply a high standard of gold, being around $18 \mathrm{~K}$. Based on the colour of other elements of the hilt, it may generally be assumed that both the plates on the pommel and on the hilt were made of gold of similar standard.

\section{Comparative Traseological Examinations}

The main aim of these examinations was to prove whether all the elements of the hilt were made at the same workshop, by the same hand and whether their damages come from the same period. For this purpose one needs to carefully examine and compare the ornamental patterns which were repeated on all the parts of the hilt. Attention must be paid to triangular patterns, which are ornamented with linear cuts, notable between the fields of the rhombes on the circumference of the pommel and on the upper side of the crosspiece (figs. 20-23a). It can clearly be seen that they were made with a different hand and using a different stylus than those on the $19^{\text {th }}$ c. side plate on the grip (fig. 23b).

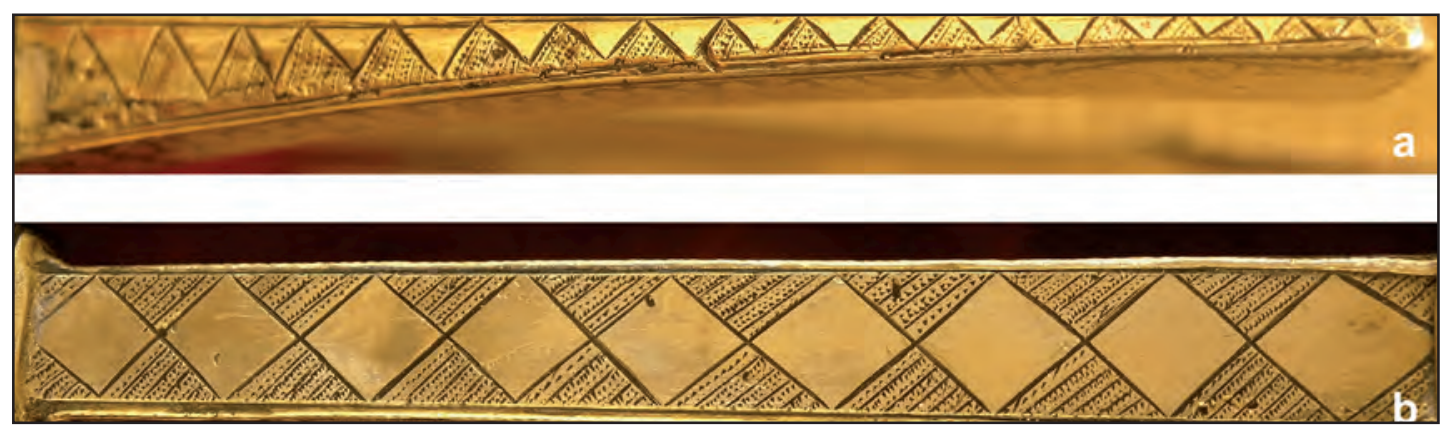

Figure 23. a. Crosspiece - a view from above. b. Side plate of the grip, added in the 19th c.

Furthermore, notable differences can be seen between these triangular patterns on the crosspiece and the pommel, the background of the grip plates and the figural representations on the crosspiece (fig. 24). These differences suggest a hand of a different artist and, as it can be supposed, a different time of origin of these parts of the hilt. This is additionally supported by the fact that the surfaces of the pommel and the crosspiece bear much more traces of wear and damage than the surfaces of the grip do. Attention is first of all drawn to the edges of the pommel and the crosspiece, which are strongly smoothed. Furthermore, there are numerous 

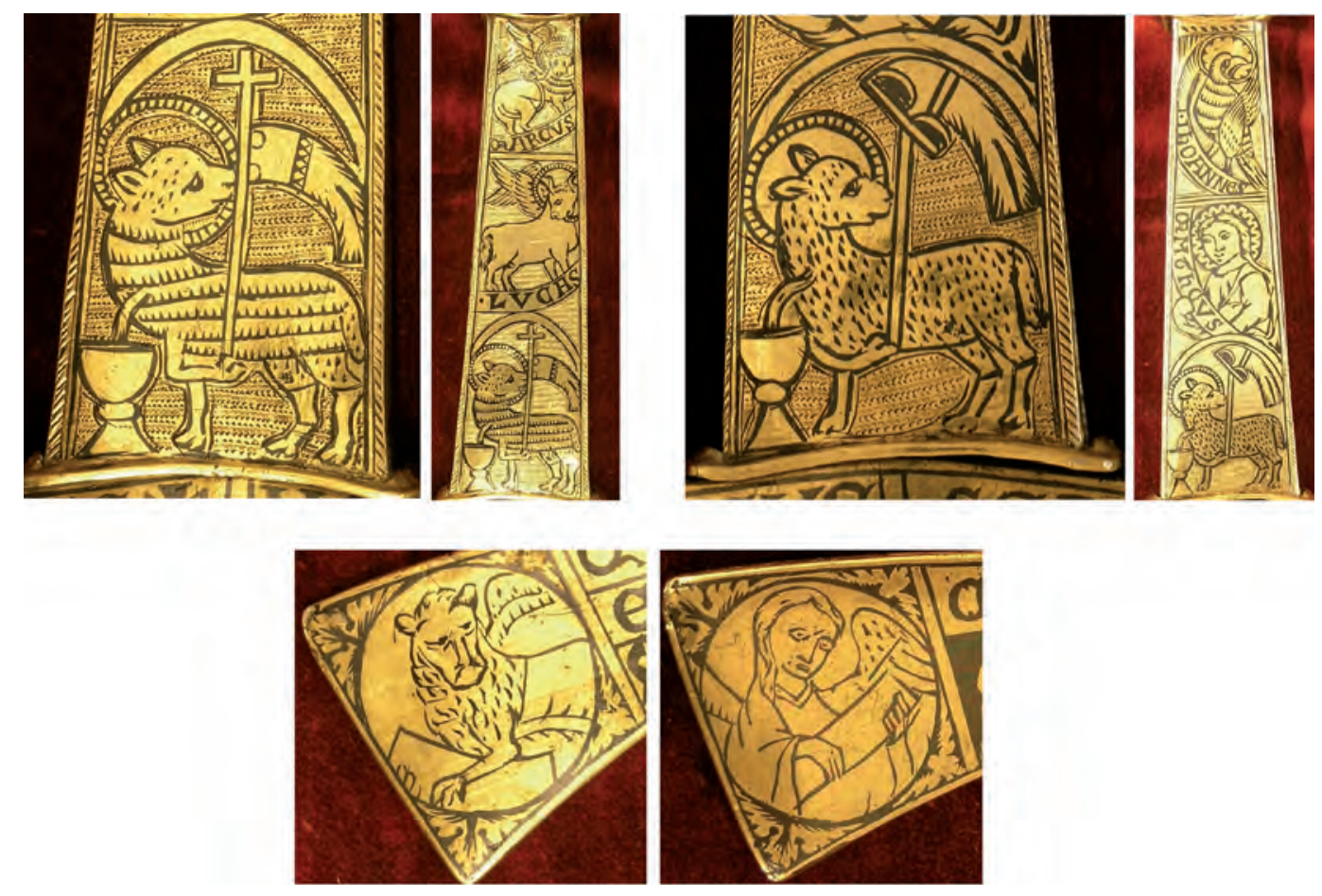

Figure 24. Figural representations on the grip and the crosspiece.

spots with deep traces of crunching in the niello. In contrast, such features are not so notable on the grip. Next, the fluted edges of the grip plates bear almost no traces of smoothing or scratching, in contrast to other parts of the hilt. This seems to confirm the assumption that the grip plates are less worn and they may have been mounted later than the pommel and the crosspiece.

It is worth mentioning that the crosspiece in all probability underwent some repair, which may be said based on file traces. The repair perhaps concerned the gold plates, which were detaching from the core near the edges and had to be soldered again. The repair was done already in the industrial era, as the file scratches run in parallel to each other and are of the same depth. This imply the use of a tool of mass factory manufacture (fig. 25).

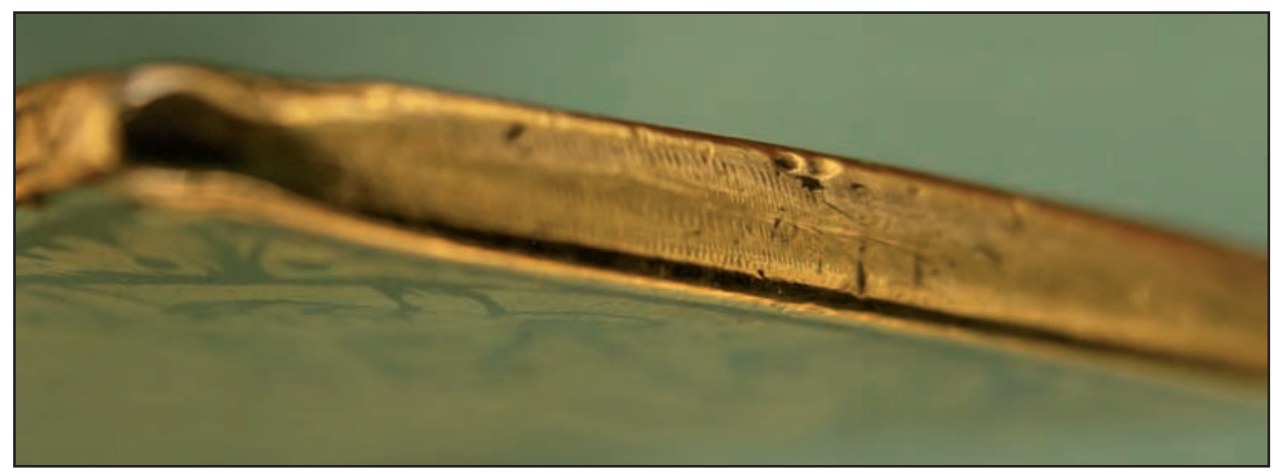

Figure 25. File scratches on the edge of the crosspiece. 
Another workshop, and perhaps a different time of origin of the grip plates, as compared to the pommel and the crosspiece, is also implied by differences between the features of figural representations. Attention is drawn to the fact that all the figural representations on the grip plates are surrounded with engraved lines in order to stress the contours of the silhouettes. This is completely absent concerning the pommel and the crosspiece (figs. 22-24). Furthermore, there are dissimilarities between the representations on both front plates of the grip. They concern different styles of the Fleece in the Agnus Dei symbols, as well as a much better artistic level of the representations on the plate with St Matthew and St John (fig. 24). On the other hand, the fluted edges of both plates are very similar to each other and they were in all probability made with the same tool. This may imply that both plates were made at the same time and at the same workshop but by two different artists.

Finally, it is worth underlining that linear cuts in the background, notable on the grip plates, are completely absent on the pommel and the crosspiece.

\section{METRICAL DATA, THE ORNAMENT AND INSCRIPTIONS}

The metrical data of the Szczerbiec are the following:

- total weight $1.260 \mathrm{~kg}$

- total length $98.4 \mathrm{~cm}$

- blade length $82 \mathrm{~cm}$

- blade width at the hilt $4.8 \mathrm{~cm}$

- maximum blade width (c. $5 \mathrm{~cm}$ from the crosspiece) $5 \mathrm{~cm}$

- blade width near the point $1 \mathrm{~cm}$

- fuller length c. $74 \mathrm{~cm}$

- average fuller width c. $2 \mathrm{~cm}$

- blade thickness $0.3 \mathrm{~cm}$

- crosspiece height along the symmetry axis of the sword $1.8 \mathrm{~cm}$

- crosspiece height near the ends $3.4 \mathrm{~cm}$

- crosspiece length along the upper edge $20 \mathrm{~cm}$

- crosspiece thickness near the grip $1 \mathrm{~cm}$

- hilt length $16.4 \mathrm{~cm}$

- grip length $10.1 \mathrm{~cm}$

- grip width near the crosspiece $3 \mathrm{~cm}$

- grip width near the pommel $2 \mathrm{~cm}$

- grip thickness $1.2 \mathrm{~cm}$

- pommel height $4.5 \mathrm{~cm}$

- pommel width $4.5 \mathrm{~cm}$

- pommel thickness $2.6 \mathrm{~cm}$

- pommel circumference band width $1.3 \mathrm{~cm}$

- pommel washer dimensions $1.1 \times 1.4 \mathrm{~cm}$

- tang rivet diameter c. $0.5 \mathrm{~cm}$

- coat of arms shield dimensions $4.5 \times 4.2 \times 4 \mathrm{~cm}$

(own examinations; see also Nadolski 1968, 112-113; Głosek 1973, 139-140, No. 12; Głosek 1984, 113-114, 158, No. 262; Żygulski 1975, 90; Chodyński 2007, 191)

The ornamentation and inscription program of the sword is presented as follows (see fig. 26): 


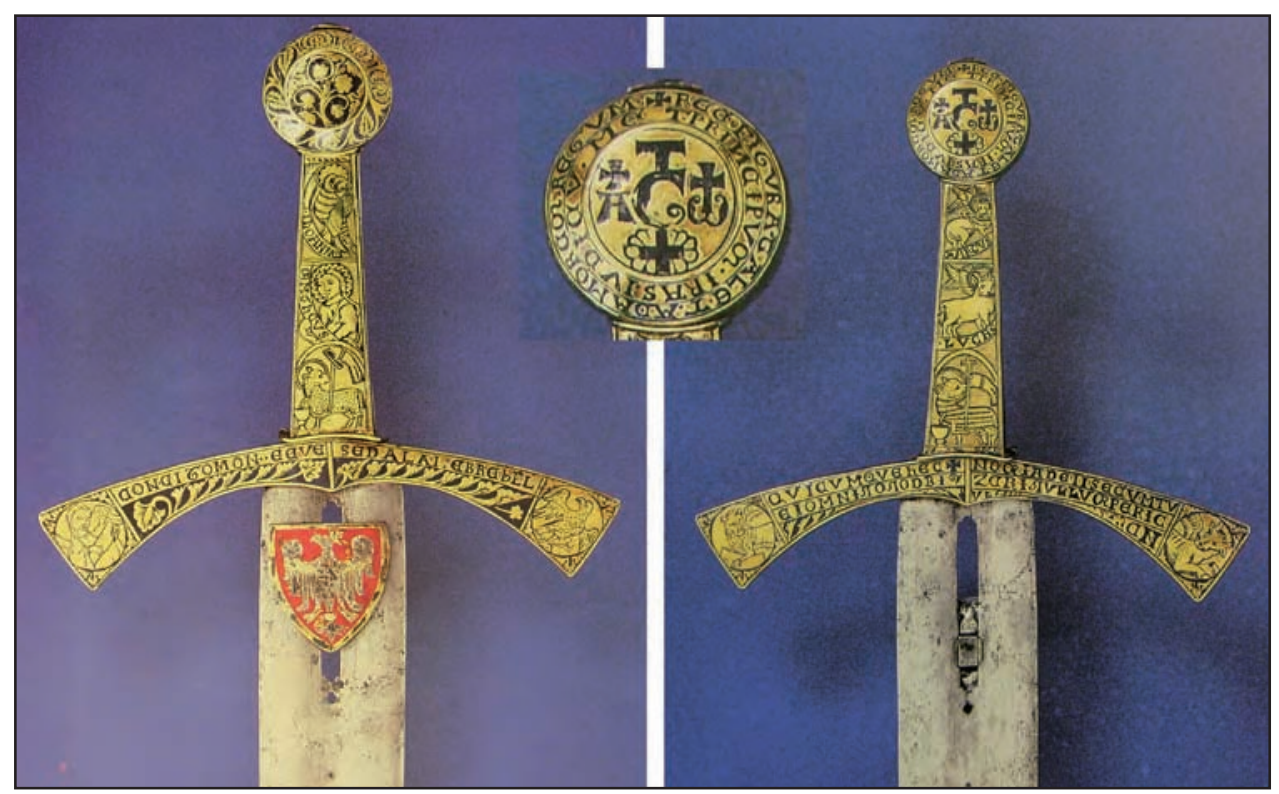

Figure 26. Hilt of the Szczerbiec. After Lileyko 1987, 72-73, figs. 62-63.

The pommel:

- on the one side there is a floral ornament in the central field (Vine Bush) and on the circumference (Vine Leaves)

- On the other side there is a symbol resembling $\mathbf{C}$ or $\mathbf{G}$ in the centre of the field. It is flanked by $\mathbf{A}$ (alpha) and $\boldsymbol{\Omega}$ (omega), with both having crosses on their tops. Above the $\mathbf{C}$ there is a symbol of $\mathbf{T}$ and below the $\mathbf{C}$ there is a cross within a dodecafoil rosette. There is an inscription on the facet $\nleftarrow$ REC $\cdot$ FIGVRA $~ T A L E T \cdot A D$ AMOREM $\cdot$ RE$\mathrm{GVM} \cdot \mathrm{ET} \cdot \mathrm{PRINCIPVM} \cdot \mathrm{IRAS}$ IUDICV $\cdot \mathrm{M}$

The grip:

- on the one side there are symbols of the Evangelists: St John (the Eagle, with an inscription IhOANNES) and St Matthew (the Angel, with an inscription MMThCVS). Below there is a symbol of the Agnus Dei with a standard on a shaft

- on the other side there are symbols of the Evangelists: St Mark (the Lion, with an inscription MARCVS) and St Luke (the Ox, with an inscription LVCAS). Below there is a symbol of the Agnus Dei with a standard on a shaft with a cross.

The crosspiece:

- on the one side there is an inscription CON · CITOMON * EEVE SEDALAI . EBREbEL with a floral ornament below. Both ends are ornamented with symbols of the Evangelists in round fields: St Matthew (the Angel - on the left) and St John (the Eagle - on the right)

- on the other side there is an inscription QVICVMQVE hEC $\nleftarrow$ NOMI[N]A DEII SECVM TVLERI[T] NVLLVM PERICVL[VM] CN EI OMNINO NOC[E]BIT. On the left side of the crosspiece below the inscription there is a floral ornament. Both ends are ornamented with symbols of the Evangelists in round fields: St Mark (the Lion - on the left) and St Luke (the $\mathrm{Ox}$ - on the right) 
As mentioned above, the side plates of the grip (now lost) bore the following inscriptions (drawn and recorded in 1764 and 1792, see Radzikowski 1898, 11, fig. I, 13, fig. II; Rożek 1987, 95, fig. 69-70; Kossecka 1999, 243, fig. 223; Wątroba 2007, 195):

\author{
LIST E $\cdot$ EST $\cdot$ GLAUD $[\ldots]$ \\ $\mathrm{h} \cdot \mathrm{BOLEZLAI}$ 'DVC [...]
}

and

\title{
CVM $\cdot$ QVO $\cdot$ EI DNS $\cdot$ OS $\cdot$ AVXIL ETVR $\cdot$ ADUS $\cdot$ PARTES $\cdot$ AMEN
}

The shield with the Royal Coat of Arms of Poland (Crowned White Eagle) is mounted in the rectangular slot of the blade. It is commonly agreed that the shield was added in the early $14^{\text {th }}$ c. during the rule of Władysław Łokietek (Sadowski 1894, 116-117; Lileyko 1987, 72; Rożek 1987, 135; Piech 1994, 119; Wątroba 2007, 196; Żygulski 2008, 317).

It must be borne in mind that preserved images testify to the fact that the hilt was often dismounted and mounted again. It cannot be therefore said with certainty which composition of the ornaments and inscriptions was the original one. A. Nadolski suggested that the front side of the sword should display images with stronger ideological impact. He implied therefore that the frontal side should contain the five symbols on the pommel, the CON · CITOMON ... inscription on the crosspiece and the symbols of St Mark and St Luke on the grip, as the artist probably intended to display all the Four Evangelists on each side of the hilt (Nadolski 1968, 111-115; Żygulski 1975, 90; Ławrynowicz 2005, Table II). On the other hand, on the oldest depiction of the Szczerbiec from 1764 the front side displays the five symbols on the pommel, St Mark and St Luke on the grip and the QVICVMQVE ... inscription on the crosspiece (Kossecka 1999, 243, fig. 223; Wątroba 2007, 195; see also Żygulski 2008, 315-316, fig. 7). It is unknown, however, whether such a composition was not altered before 1764 .

Some elements of the ornamentation seem to be fairly obvious for interpretation and they are widespread in Christian art. The Vine Bush is a self-evident symbol of Christ Himself. It can also be related to the Tree of Life, which stands for the victory over Death and Eternal Life (Kirschbaum 1968, 258-268; Kirschbaum 1972, 491-496; see also Chodyński 2007, 192). The presence of the Agnus Dei and the Evangelists is completely comprehensible in the Christian context.

The same can be said about $\mathbf{A}$ (alpha) and $\boldsymbol{\Omega}$ (omega) symbols, which evidently refer to God as the Beginning and the End (Revelation 1, 8; Revelation 21, 6; Revelation 22, 13; see also Kirschbaum 1968, 1, and Förstner 1990, 28-30). Concerning these symbols in a weaponry context, attention is drawn to the mid-12 ${ }^{\text {th }}$ c. Historia Karoli Magni et Rotholandi by PseudoTurpin. This possibly Spanish-origin work mentions the symbols of $\mathbf{A}$ and $\boldsymbol{\Omega}$ on the pommel of Roland's Durendal (Turpini Historia Karoli Magni 1880, C. XXII: 45-46; it was already noticed by Ciampi 1819, 5, but for some reason went unrecorded in later scholarship concerning the Szczerbiec!). This mention is of enormous significance, as it leads the inquiry into the world of courtly and chivalric culture. Furthermore, a possible Spanish origin of this text is relevant for the origin of the Szczerbiec itself. It is discussed in detail in the further part of this paper.

The $\mathbf{T}$ symbol was usually interpreted as the Greek tau or a so-called crux comissa. It was a symbol of Redemption related to the Sacrifice of Christ and was often used as a protective sign (see Ezekiel 9, 2; Ezekiel 12, 7; Revelation 7, 2-8; Kirschbaum 1970, 570; Kirschbaum 


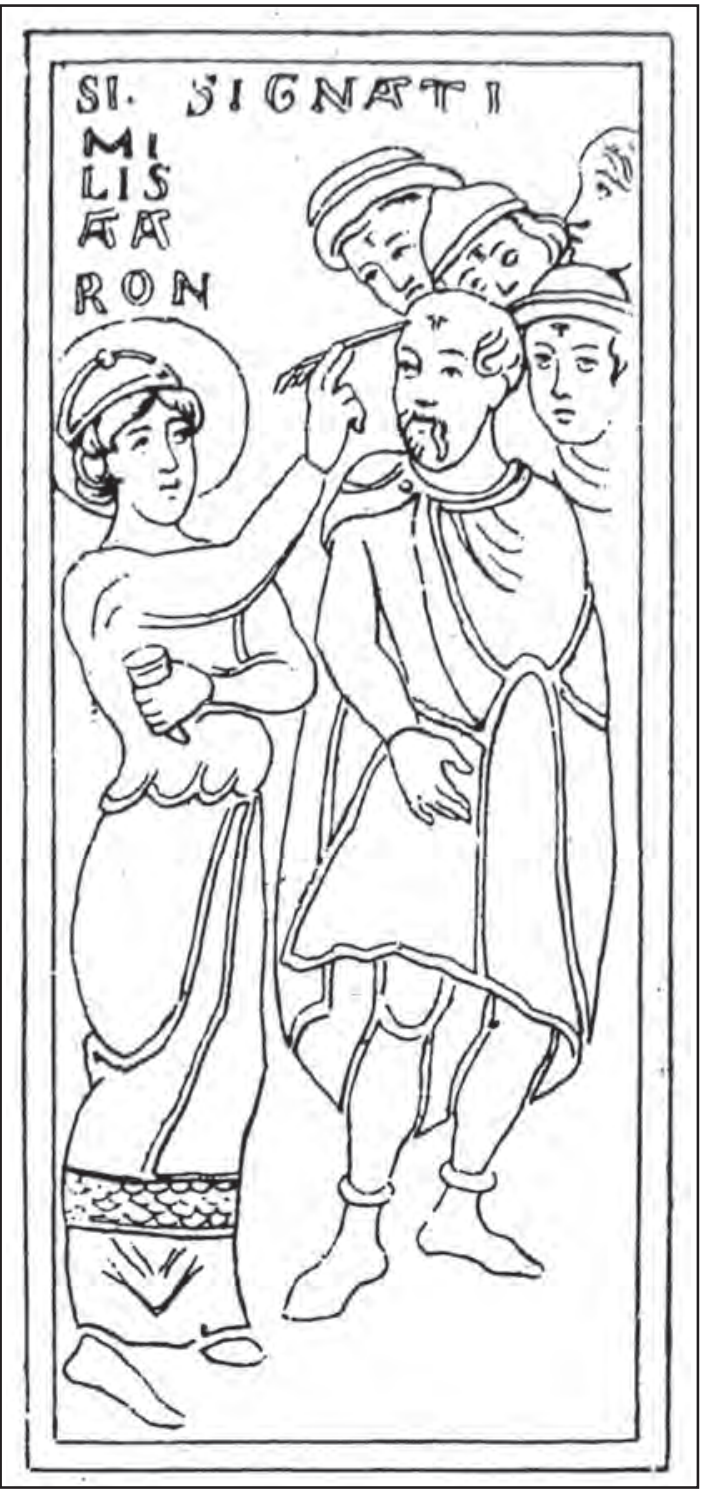

Figure 27. Aaron painting the $\mathbf{T}$ sign on the foreheads of Israelites. A 12th c. cross from Saint-Bertin. After Mâle 1947, 157, fig. 123.
1972, 158; Förstner 1990, 13-14, 30-31; Chodyński 2007, 192; for some selected examples of the use of $\mathbf{T}$ in this context in the Christian art see fig. $27-$ a $12^{\text {th }}$ c. cross from Saint-Bertin, with the image of Aaron painting the sign on the foreheads of Israelites; fig. 28 - the same scene on a $12^{\text {th }}$ c. stained glass window from Saint-Denis; fig. 29 - the Maciejowski Bible, c. 1250, with the $\mathbf{T}$ sign on the houses of the Israelites in Egypt). Alternatively, the $\mathbf{T}$ may stand for the so-called tau-cross, associated with Roman crosses as execution instruments and therefore standing for the Death of Christ.

The dodecafoil rosette with the cross has been interpreted as the Cloud of Light - a symbol of Resurrection, with its twelve parts perhaps standing for twelve apostles (Chodyński 2007, 192). The Cloud in fact appears in numerous passages of the Bible with regard to either God in general or Christ in particular (e.g., Exodus 13, 21; Daniel 7, 13; Matthew 24, 30; Matthew 17,2; Matthew 26, 64; Mark 9,6; Mark 13, 26; Luke, 9, 34; Acts 1, 9; Revelation 1, 7; Revelation 14, 14-16; see also Förstner 1990, 105-107). Alternatively it could simply stand for the Light of God (e.g., the reliquary of St Gondulf, c. 1165-1200, with the figure of Hope, holding a rosette with the cross, Lemeunier 2007a, 14, fig. 3, see fig. 30; octofoil leaves or rosettes are also notable on the alter of St Kilian and St Liborius, c. 1100, made by Roger of Helmarshausen, see Petzold 1995, 24, fig. 13; see also Petzold 1995, 51, fig. 34). Of particular interest is that the cross in a dodecafoil or octofoil rosette frequently appears on a series of Crusader coins, related to Bohe-

mond VII Count of Tripoli (1275-1285) (see Coin Archives at www.coinarchives.com; Coins of the Crusaders 2005, Nos. 72-77; Folda 2005, 360, 361, fig. 222, 466, 467, fig. 316, 468, fig. 317; as an example, see a silver castle gros of Bohemond, fig. 31).

No satisfactory interpretation has been offered so far concerning the $\mathbf{C}$ in the middle of the pommel. J. N. Sadowski analysed it together with the $\mathbf{T}$ and related it to a hospital order (Hospital Brothers of St Anthony) founded by a nobleman Gaston of Dauphiné in 1095. In this interpretation the $\mathbf{T}$ was the cross of St Anthony, whose intercession healed Gaston's son from disease. The $\mathbf{C}$ was in fact to be a $\mathbf{G}$ (for Gaston), left under the cross to commemorate the order's founder (Sadowski 1894, 91-92). Unfortunately, the authors of the present paper could not identify any image with the St Anthony's cross and a G. On the other hand, 
Prof. Żygulski simply considered the $\mathbf{G}$ as an ornamental addition to the T (Żygulski 2008, $332,347)$. It seems, however, that it must have some much deeper meaning. If one interprets it as a floral symbol, it may easily be considered as a Root or a Branch. In several passages of the Bible Christ is referred to in a similar manner (e.g., Isaiah 11,1 - virga et flos or «twig and flower», Revelation 22, 16 - radix et genus David or «root and offspring of David», all pointing to Christ as the Beginning and the End; see also Kirschbaum 1972, 549-550; Förstner 1990, 206-208). Again, no similar example of this symbol has been identified so far. Alternatively, the $\mathbf{C}$ could simply stand for CHRISTUS. Although this way of recording the Name of Christ in visual art is unusual (instead of IHS, IC XC or the like), one could point out an image from a manuscript sacramentary, written per-

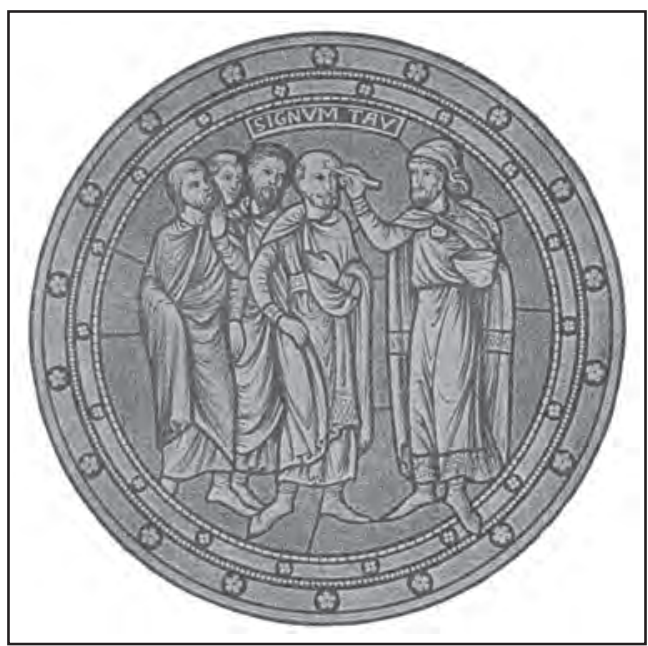

Figure 28. Aaron painting the $\mathbf{T}$ sign on the foreheads of Israelites. A 12th c. stained glass window from Saint-Denis. After Mâle 1947, 155, fig. 122.

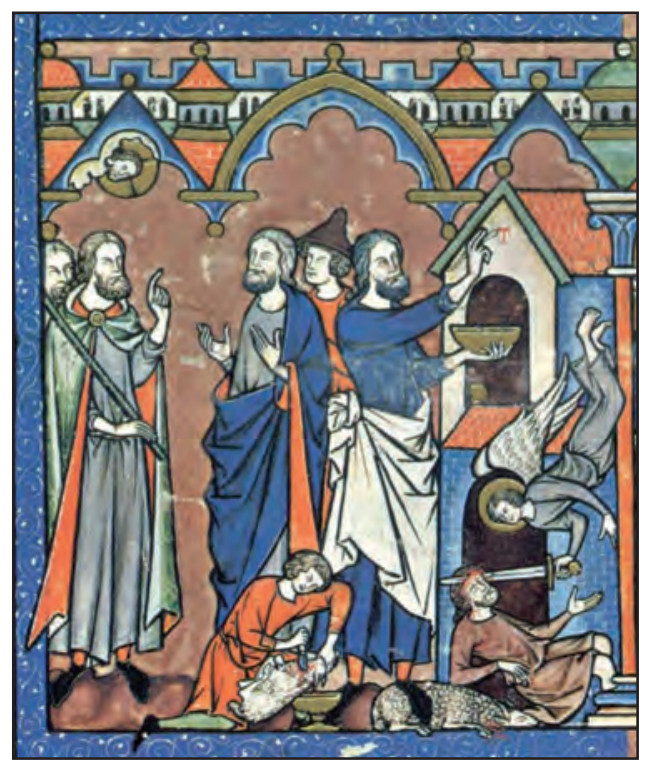

Figure 29. T sign on the houses of the Israelites in Egypt. The Maciejowski Bible, c. 1250. After Bible of Maciejowski 1975, 8v, fig. 62.

haps upon the order of Herold Patriarch of Jerusalem (1225-1239). In the Crucifixion scene the name of Christ is written as IHS CRISHTUS (Folda 2005, 210-211, fig. 118; see fig. 32). No matter which interpretation is correct, it may be taken for granted that a symbol between $\mathbf{A}$ and $\boldsymbol{\Omega}$ cannot refer to anything else than God.

Concerning the inscriptions, the CON CITOMON - EEVE SEDALAI . EBREbEL proved to be the most controversial. The three last words were interpreted as corrupted Hebrew Names of God: the EEVE stands for vowels to be inserted into the Sacrosanct Name of YHWH (Yodh - He - Waw - He), the SEDALAI stands for SHADDAI ELOAH/ELOHIM («Almighty Supreme»), and the EBREbEL stands for $\mathrm{AB}$ RABI EL («Father Omniscient God») (see Jewish Encyclopedia: Names of God). The CON - CITOMON was either read as corrupted Hebrew KONE ZITU OMON, meaning «(They) arouse zealous faith» or Latin CONOR CITARE NOMINA ( I dare to mention the names»). J. N. Sadowski favoured the first option (Sadowski 1894, 105-108), while Prof. Żygulski preferred the other one (Żygulski 2008, 351). The other assumption, although of most interest, may be questioned on the grounds that in the Vulgate there is no example of Nomen Dei or Domini with the verb citare. Instead, one finds invocare («invoke»-Genesis 4, 26; 1 Kings 5, 11; 2 Kings 6, 2; Proverbs 13, 6; Deuteronomy 14, 23; 1 Corinthians 1, 2) or vocare («call, invoke» - Genesis 5, 26; Revelation 19, 13), laudare («praise» - Ecclesiastes 47, 12; Joel 2, 26), nominare («name»- 2 Timothy 2, 19) or glo- 


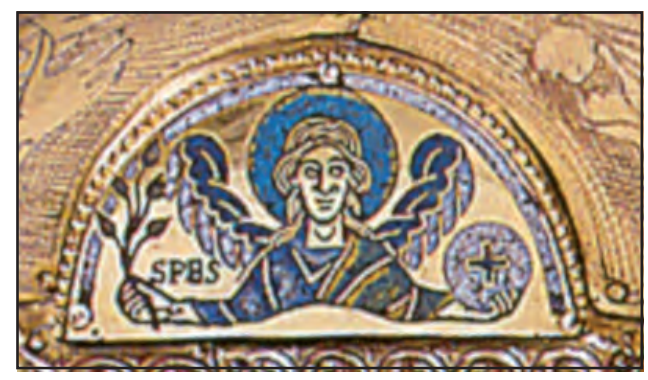

Figure 30. Reliquary of St Gondulf (detail), c. 1165-1200, the Mosan art. The Hope holds a rosette with the cross. After Lemeunier 2007a, 14, fig. 3 .

ther in Hebrew or in Aramaic. He discussed the Hebrew KONE «The Creator» (as the name of God), and a possible Aramaic «ki tomun» («Then you will swear») for CITOMON, but he found both unacceptable. Alternatively, he also suggested a Latin reading as «Concito mostra» or «Concito moneo» in the sense of «I announce marvellous things» or «I announce I admonish». Concerning the names of God, he read the EBREbEL as Aramaic BREH DI EL («The Son of God»). He did not make any decisive rificare («glorify»-Isaiah 24, 15). Alternatively, one could propose a Hebrew-Latin hybrid with the Latin concit(at) - «arouse» and the corrupted Hebrew ay-moon' (א y I , Aleph - Mem Wav - Nun) - «faith, trustworthiness.» All in all, the meaning of the inscription would be «(They) arouse (zealous) faith (Names of God): God Almighty Supreme Father Omniscient God.»

Yet another interpretation was proposed by P. Muchowski. He rejected Sadowski's reading of KONE ZITU OMON in the sense of «excite zealous faith» as illegible and non-existent ei-

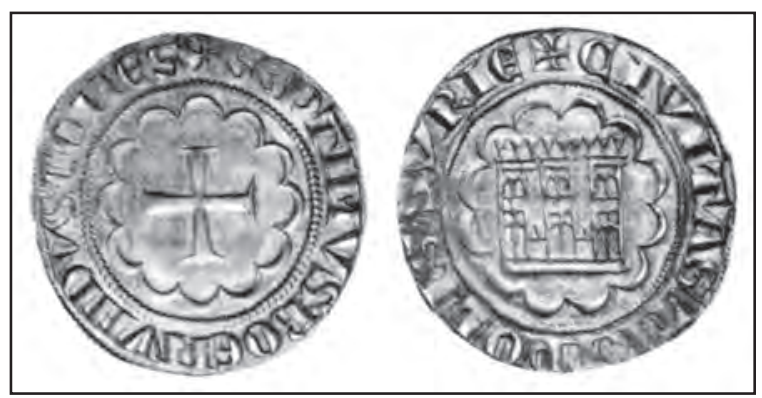

Figure 31. Cross in a dodecafoil - a silver castle gros of Bohemond VII Count of Tripoli (1275-1287). After Folda 2005, 468, fig. 316.

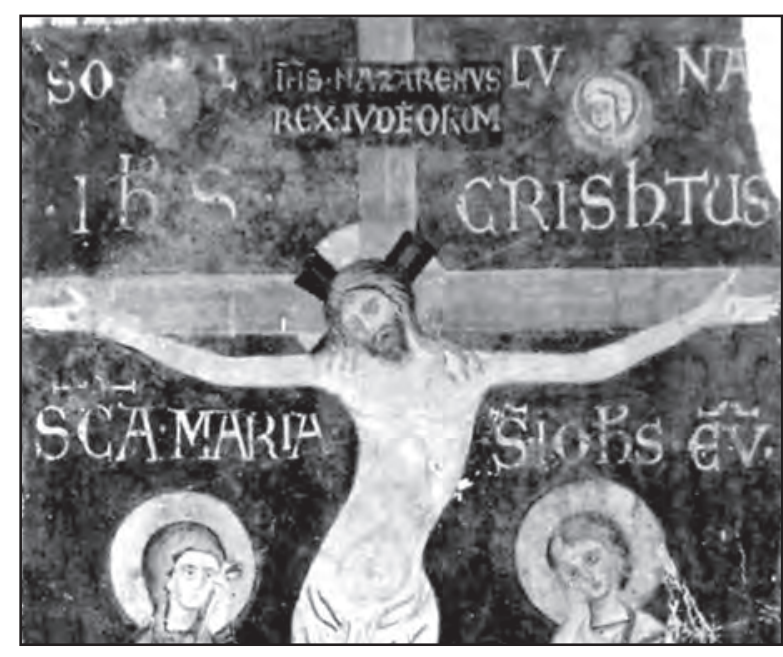

Figure 32. Name of Christ recorded as IHS CRISHTUS. The Sacramentary of Herold Patriarch of Jerusalem (1225-1239), British Library, Egerton MS 2902, fol. 14v. After Folda 2005, 211, fig. 118. proposal for the SEDALAI, although he initially considered «The Lamb of God» or «My Lamb of God». He identified the EEVE either with the Aramaic «ehwe» or the Hebrew «ehye» (i.e., «I Am» - the name of God from the Book of Exodus 3: 14). Generally, he did not consider the whole inscription as Hebrew, but rather as «inspired by some Hebrew and Aramaic terms». Of course, he fully agreed that the inscription had strong mystic significance as a sort of protective amulet that used the names of God (Muchowski 2006-2007). D. Budzioch and M. Tomal state with right that the Hebrew original may have been seriously distorted in the process of transmission from a Hebrew speaker to a Christian craftsman who worked 
on the sword. They rather opt for the Latin «Concito» (understood as «to summon») than for any Hebrew reading. For OMON, they propose the Hebrew «"amon» («Faithful») while for EEVE they suggest «ahava» («love»). With regard to SEDALAI, they propose «The Lamb of (my God)». For EBREbEL, they propose to emend it as DEBREhEL which would stand for «The Word(s) of God». In conclusion, they propose to read the further part of the inscription as four Names of God: «The Faithful Shepherd», «Love», «The Lamb of the Lord», and «The Word of the Lord». This, in their opinion, would perfectly match the images of the Lamb of God and Four Evangelists on the hilt (Budzioch, Tomal, 2010).

This inscription is directly related to that on the other side of the crosspiece. It says QVICVMQVE hEC $\nleftarrow$ NOMI[N]A DEII SECVM TVLERI[T] NVLLVM PERICVL[VM] CN EI OMNINO NOC[E]BIT, which stands for «Whoever will carry these Names of God with himself, no danger will injure him altogether.» The double I in DEII was sometimes interpreted as DEI YAHWEH (Sadowski 1894, 105-106; Kopera 1917, 231), but in this case one needs to accept the opinion of Prof. Żygulski, who considers it as one of numerous mistakes of the engraver (Żygulski 2008, 328-329, 351). Such mistakes are also notable in the inscription on the pommel. It says $\&$ REC $\cdot$ FIGVRA $\cdot$ TALET $\cdot$ AD AMOREM $\cdot$ REGVM $\cdot$ ET $\cdot$ PRINCIPVM $\cdot$ IRAS IUDICV $\cdot \mathrm{M}$ and refers to the symbols on the pommel. It means «This figure extends to the love of kings and dukes (and) the wrath of judges.» It undoubtedly points to the sword being a gladius iustitiae («sword of justice») - a symbol of judicial authority of a ruler (e.g., Kopera 1917, 231; Walicki 1968, 300-301; Lileyko 1987, 23, 63; Ławrynowicz 2005, 108-110; Wątroba 2007, 194).

The side plates of the grip with inscriptions are lost now. It must be stressed again that the plate with the name of Duke Bolesław was already damaged in 1764, rendering the inscription partially legible (Radzikowski 1898, 11, fig. I, 13, fig. II; Rożek 1987, 95, fig. 69-70; Kossecka 1999, 243, fig. 223; Wątroba 2007, 195; for a closer view of the drawings from

LISO Q.ESL:G LMVOO h.BOLAZLAI'OI'C

\section{LIST E - EST $\cdot$ GLAUD h · BOLEZLAI ' DVC}

CVOR.QVO.GFDTES.OS.AVXIL CÜVR.A DCS.PURz QUS.HOzEI

CVM $\cdot$ QVO EI DNS $\cdot$ OS $\cdot$ AVXIL ETVR $\cdot$ ADUS $\cdot$ PARTES $\cdot$ AMEN

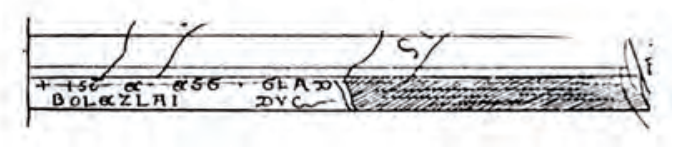

Figure 33. Closer view of the side plates of the grip as drawn in 1764 (top) and 1792 (bottom). After Kossecka 1999, 243, fig. 223, and Radzikowski 1898, 11, fig. 1 .
1764 and 1792 see fig. 33). Those inscriptions said:

LIST E $\cdot$ EST $\cdot$ GLAUD [ with the room for 2 - 3 words more]

$\mathrm{h}$ - BOLEZLAI ' DVC [with the room for $2-3$ words more]

that is ISTE EST GLADIUS [...] $\mathrm{H}$ [ONORABILIS?] BOLEZLAI DUCIS [...] and meaning «This is the sword [...] of h [onourable?] Duke Bolesław [...]» and

CVM $\cdot$ QVO $\cdot$ EI DNS · OS · AVXIL ETVR $\cdot$ ADUS $\cdot$ PARTES $\cdot$ AMEN

that is, CUM QUO EI DOMINUS OMNIUM SALVATOR AUXILIETUR ADVERSUS PARTES AMEN and meaning «With whom the Lord Saviour of All, may He support him against adversaries. Amen.»

Regarding the other inscription, it is of utmost interest that it sounds somehow 
similar to the text in the Chronicle of Great Poland concerning the Szczerbiec: ... Huic enim per angelum dicitur gladius fuisse datus, in quo omnes suos adversarios cum Dei iuvamine vincebat ... - «To whom [Bolesław Chrobry], as it is said, a sword was given by the angel, with which he defeated all his adversaries with the help of God» (Chronica Poloniae Maioris 1970, c. 11: 16-18). This is perhaps another premise that the record of the chronicle was shaped by the tradition of the sword as such.

The Hebrew or Latin-Hebrew inscription on the crosspiece has long tempted several researchers to consider the sword to be related to the Kabbalah symbolism (e.g, Sadowski 1894, 109; Walicki 1968, 300-301; Ławrynowicz 2005, 108-110, Wątroba 2007, 194). This assumption was fully developed by J. P. Sobolewski. He proposed that the Hebrew inscription and the Christian symbols on the hilt were to stand for a reconciliation between the Old and the New Testament. Furthermore, he considered the names of the Evangelists to bear encrypted names of the Old Testament prophets and thus fulfill a similar function. In order to support his assumption of the relation of the Szczerbiec to Bolesław Pobożny (the Pious), Duke of Great Poland (died 1279), Sobolewski even suggested that the sword may have been granted to Duke Bolesław by local Jews, to whom Bolesław granted a protective privilege (the first one in Poland) in 1264 (Sobolewski 1998, 84-92).

This Kabbalah theory has rightfully been criticised by Prof. Żygulski. This scholar has stated with right that it would have been completely unacceptable for an orthodox Jew to combine the Names of God with Christian symbols (Żygulski 2008, 344, 349). Furthermore, a Latin transcription of the Names would have inevitably lead to a corruption of the text (completely unacceptable in the Jewish religion!), which would have rendered the inscription useless and even dangerous to the owner of the sword (Scholem 1996, 48-51 ff). The Kabbalah, being a mystical doctrine within the Jewish theology, was known to a handful of Jews in the Iberian Peninsula at that time at a possibility of its transfer to non-Jews is to be excluded (a letter of Prof. Joseph Dan, Hebrew University of Jerusalem, to G. Żabiński from 1 July 2008). Moreover, although there was a room for magical-practical use of the Kabbalah, it was definitely not the essence of the doctrine (Scholem 1996, 133-136, 176-184, 189-207). Eventually, would it have made any sense to encrypt Old Testament ideas and symbols, bearing in mind that it was completely natural to display them in medieval Christian art?

The tradition of using Divine names for protective purposes dates back to the Antiquity and it is common for many religions (see, e.g., Jewish Encyclopedia: Names of God, Amulet; Trachtenberg 1939, 140-142, 147, 152-153, 159-160, 258). Furthermore, as rightfully pointed out by Dr Gideon Bohak, numerous Hebrew-origin incantations (referred to as voces magicae or «magical voices») with the Names of God entered the "public domain» of the magic already in the Antiquity. In many cases they became significantly corrupted in the transliteration process and it often occurred that non-Jewish users had no idea about their true meaning or origin (Bohak 2003, 69-81, with an extensive list of scholarship). It cannot be therefore excluded that the inscription on the Szczerbiec may belong to this group and it may have derived from a popular tradition. Its origin, however, definitely requires further examination. A good example of the Hebrew tradition being mixed with the Christian symbols is the ring of Emperor Lothar III (before 1137). It bears the inscription $+\mathrm{I} \boldsymbol{Q}[\mathrm{Mem}] \boldsymbol{T}[\mathrm{He}] \boldsymbol{Q}[\mathrm{Mem}] \mathrm{DER}+\boldsymbol{\Omega}$ et $\mathbf{A} \mathrm{I}+$. The Hebrew letters stand for meh 'lek haw maw-shee'-akh or «The King is the Messiah» and the DER means DEUS EST REX or «God is King» (Borrmann 1995, 148-149; see fig. 34).

Similarly ardent controversies have been provoked by the intitulation of Duke Bolesław on the hilt of the sword. As the original sword was already damaged when its first images were drawn, attention was paid to the Radziwiłl replica. According to the inventory from 1740, the full inscription said ISTE EST GLADIUS PRINCIPIS ET HAEREDIS BOLESLAI DUCIS 


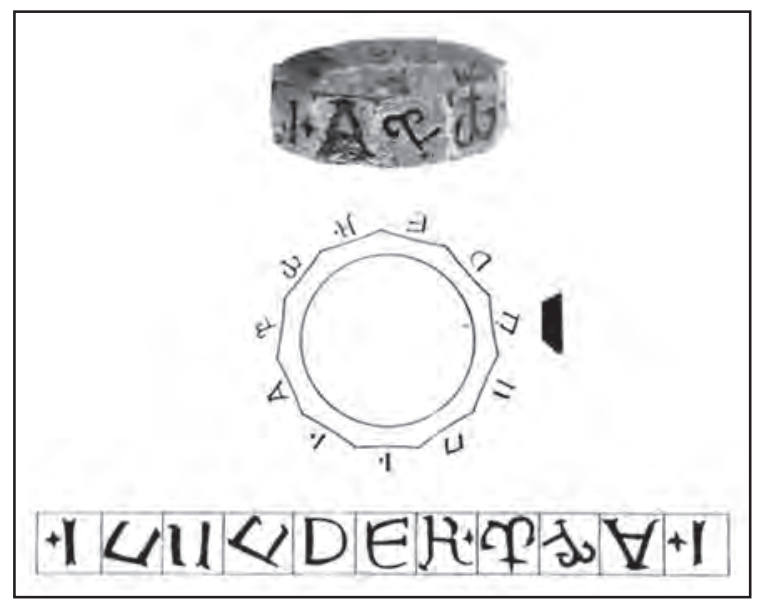

Figure 34. Ring of Emperor Lothar III (before 1137). After Bormann 1995, 148 .
POLONIAE ET MAZOWIAE, LANCICIAE or «This is the sword of Prince and Heir Bolesław Duke of Great Poland and Masovia, Łęczyca» (Łepkowski 1881, 3; Sadowski 1894, 112-113). The first issue is to what exent the inventory may be considered as trustworthy, as the other inscription on the hilt was deciphered with several mistakes: FELIX CUM QUO DOMINUS SUOS AUXILIATUR AD OMNES FORTES. AMEN (possible misintepretations, made already by the artistan who made the Radziwiłł replica, were suggested by A. Nadolski, Nadolski 1968, 120). Although the word PRINCEPS could be accepted and the HAERES may have standed for a ruler who claimed the authority in a given realm, the main difficulty was that there was no duke Bolesław in $13^{\text {th }} \mathrm{c}$. Poland who ruled in the lands of Great Poland, Masovia and Łęczyca at the same time.

The inscription was considered as fully trustworthy by J. N. Sadowski. He related the sword to Duke Bolesław of Masovia, the paternal uncle of Władysław Łokietek. Furthermore, following his assumption of the Szczerbiec originally being a Teutonic sword, he proposed that the weapon was granted to Bolesław by the Teutonic Knights, as it was Bolesław's father, Duke Konrad of Masovia, who invited them to Poland. Finally, he suggested that the sword was inherited by Bolesław's brother, Duke Kazimierz of Cuiavia, and then by Władysław (Sadowski 1894, 112-117). On the other hand, W. Semkowicz considered the original intitulation as stating ISTE EST GLADIUS PRINCIPIS BOLESLAI DUCIS POLONIAE. The words ET HAEREDIS and ET MASOWIAE, LANCICIAE may have been added by Władysław Łokietek to stress his rights to the whole territory of Poland (Semkowicz 2002, 504-505, 558; a possible addition by Władysław Łokietek was also implied by Żygulski 1975, 92 and Rożek 1987, 140).

J. P. Sobolewski rejected the possibility of the intitulation having been forged by Władysław Łokietek. It seems that he rightfully stressed the fact that Władysław would have rather exposed the Royal and not the Ducal title of Bolesław. J. P. Sobolewski suggested that the intitulation was originally written with abbreviations and that it originally stated POSNANIAE (Poznań, one of Great Poland's Ducal sites) or POLONIAE MASOVIAE LANDE (Ląd, one of Great Poland's castellanies). He was aware that such an intitulation never occurred in Duke Bolesław's Pobożny chancery's practice, as Duke usually used titles of Dux Poloniae or Dux Maior Poloniae. Although for most time of Bolesław's rule Great Poland was divided between him and his brother Przemysł I (died 1257) and then Przemysł I’s son Przemysł II (died 1296), the divisions were not reflected in Bolesław's title. He proposed, however, that the title of Ląd may have been related to Bolesław's wars over the castellany of Ląd with Duke Kazimierz of Cuiavia in 1260-1261. The title of Masovia may have come from Bolesław's possible guardianship of minor heirs of that land in 1262-1263. In summary, the intitulation was one more argument to point out Duke Bolesław Pobożny of Great Poland as the original owner of the Szczerbiec (Sobolewski 1998, 77-82; for the conflicts over Ląd and the Masovia's affair see also Żmudzki 2000, 67, 88-89, 98-99, 104-105, 130-131, 139-140; Świeżawski 2006, 42-45).

This assumption has recently been criticised by Prof. Żygulski (Żygulski 2008, 315, 344). Furthermore, some more points may be added. As the castellany of Ląd was an integral part 
of Great Poland, its acquisition may have been reflected in the title of Ląd's conqueror (which was in fact done by Duke Kazimierz in 1241, when he called himself Dux Coiaviae et Landensis - «Duke of Cuiavia and Ląd,» see Codex Diplomaticus Maioris Poloniae 1, No. 228). It would have made no sense, however, to do so by the ruler who was anyway Duke of Great Poland. Furthermore, the use of the title of Masovia would explicitly mean either the rule in this land or at least claims to it, and not merely a guardianship. It seems, therefore, that the original intitulation on the Szczerbiec most probably said DUCIS POLONIAE.

Other controversies have been provoked by the symbols on the pommel. The $\mathbf{T}$ and the dodecafoil rosette with a cross gave rise to an intriguing assumption by Prof. Zdzisław Żygulski jun. Basing his proposition on an earlier work by R. T. Prinke (1983), Prof. Żygulski suggested that the sword may be related to the Knights Templar. According to this interpretation, the $\mathbf{T}$ is an abbreviation from TEMPLUM and the rosette with the cross is a so-called Rose of Jericho, a symbol of Resurrection. Furthermore, this renown scholar assumed that the ornamentation program of the hilt perfectly fit into theological interests of the Order of the Temple. This especially concerned the Hebrew names of God on the crosspiece, considered as an attempt at reconciling the Old to the New Testament (Żygulski 2008, 347-352).

As mentioned, attempts at relating the Szczerbiec to the military orders are already of $19^{\text {th }}$ c. origin. The assumption by Prof. Żygulski is enormously interesting; it seems, however, to be rather risky. First of all, according to the authors' best knowledge, no examples of the T symbol and the rosette with the cross have been discovered so far in association with Knights Templar. Based on preserved examples of Templar seals, it was perhaps the Temple itself that was considered as the most significant symbol of this order. Furthermore, it is known that the rules of the military orders explicitly banned the ornamentation of weapons. Finally, it could be debated whether Knights Templar actually pursued theological studies which would be advanced enough to enable them to speculate on the relations between the Old and the New Testament (on the Templars see, e.g., Bauer 2003; de la Croix 2006; Nicholson 2005; Dr Helen Nicholson explicitly denied any relation of the Szczerbiec to Knights Templar, a letter to G. Żabiński from 17 March 2008).

On the other hand, it is notable that the symbols of of $\mathbf{A}$ and $\mathbf{\Omega}$ and the Agnus Dei may frequently be found in the iconography of the military orders. J. Folda suggested that there may be a special relation beyond a common Christian symbolism between $\mathbf{A}$ and $\boldsymbol{\Omega}$ and the Order of St John. This is based on an anonymous coin of the Kingdom of Jerusalem, dated 1187-1192, with the True Cross and a pendant $\mathbf{A}$ and $\boldsymbol{\Omega}$ from the lower crossarm (Folda 2005, 47-48, fig. 14; see fig. 35). The same composition of the True Cross and a pendant $\mathbf{A}$ and $\boldsymbol{\Omega}$ is notable on

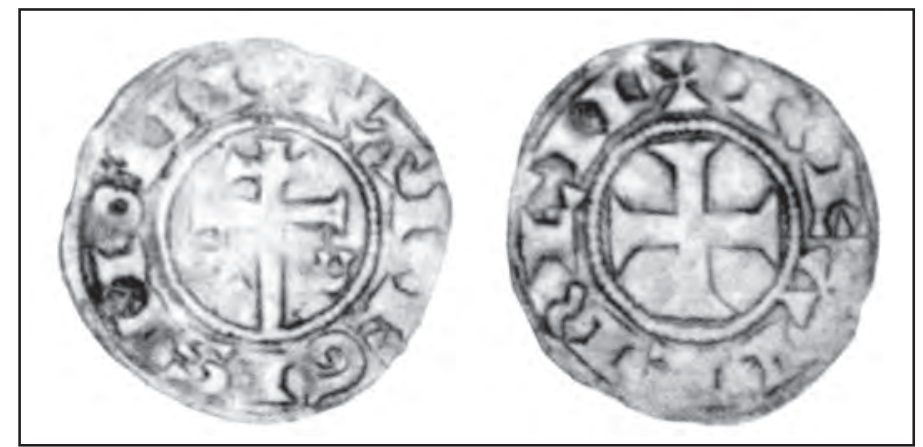

Figure. 35. True Cross with a pendant A and $\boldsymbol{\Omega}$. A coin of the Kingdom of Jerusalem, 1187-1192. After Folda 2005, 47, fig. 14. 


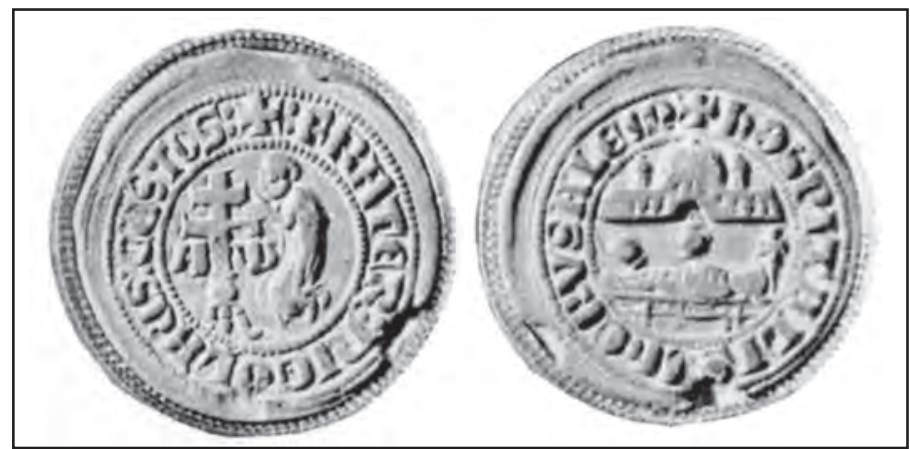

Figure 36. True Cross with a pendant A and $\boldsymbol{\Omega}$. A seal of the Johannite Grand Master Nicholas de Lorgne (1277-1285) (Folda 2005, 468, fig. 317). a seal of the Johannite Grand Master Nicholas de Lorgne (1277-1285) (Folda 2005, 467-468, fig. 317; see fig. 36). Of special significance is a paten of a chalice from the Johannite church of St John and the Holy Virgin in Werben (Saxony), dated c. 1250. The image of Christ on the paten is flanked with $\mathbf{A}$ and $\mathbf{\Omega}$. Most interestingly, these symbols are mounted with crosses, as it is

the case with the Szczerbiec (Fuhrmann 2001, 88-109, figs. 1-13, 188-189, Cat. Nos. 15 and 16; see fig. 37). This item is of particular importance, as it also demonstrates some notable epigraphical analogies to the Szczerbiec (discussed below). Concerning Knights Templar, an example is offered by the archivolt of the Templar grange in Montsaunès (France). The XP (chi-ro) is flanked by $\mathbf{A}$ and $\mathbf{\Omega}$, with the $\mathbf{S}$ (for serpens, a symbol of defeated Satan) being visible below (Fuguet and Plaza 2005, 55; see fig. 38). This combination, however, may have been influenced from neighbouring Spain, where it seems to have been especially popular (see, e.g., a portal of the Romanesque church of San Román in Cirauqui (Navarra), Künstler 1968, 104, No. 89, fig. 89; a charter of St Ferdinand King of Castille from 1230, De Las Casas 1857 , fig. 73).

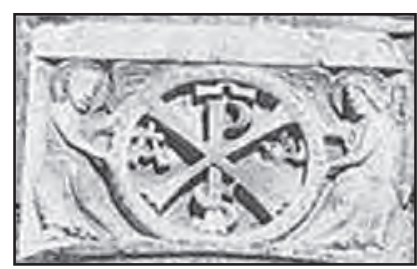

Figure 38. XP (chi-ro) flanked by $A$ and $\Omega$. The archivolt of the Templar grange in Montsaunès (France). After Fuguet and Plaza 2005, 55.

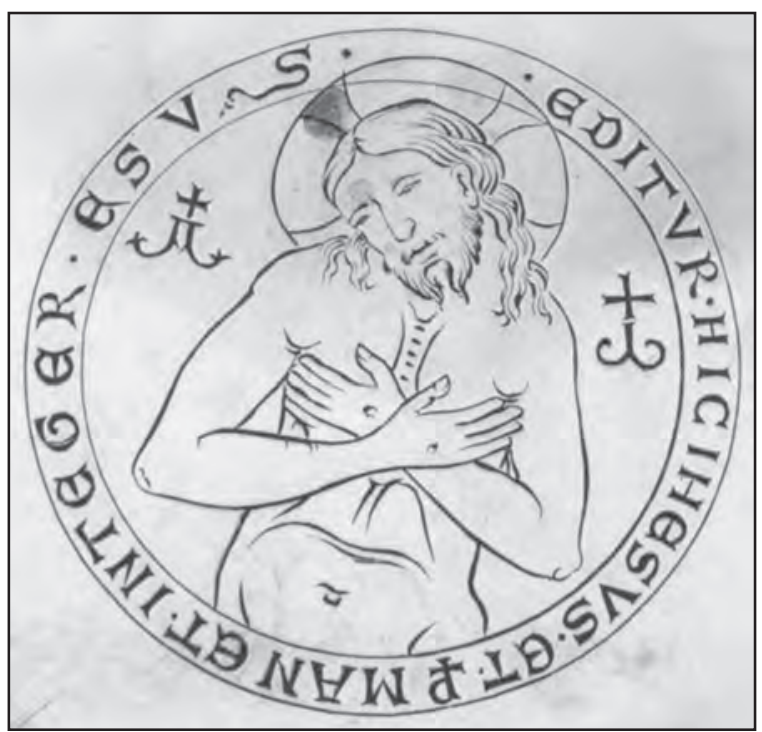

Figure 37. Christ flanked with $\mathrm{A}$ and $\Omega$ with crosses on tops of them. A paten from the Johannite church in Werben (Saxony), c. 1250. After Fuhrmann 2001, 89, fig. 1).

All in all, it was suggested with right that the symbols and the inscriptions on the Szczerbiec provided the sword with features of a protective talisman (see, e.g., Sadowski 1894, 105109; Sobolewski 1998, 88-92; Ławrynowicz 2005, 108-110). This was another role the weapon was originally supposed to fulfill, apart from being the «sword of justice.» 


\section{EPIGRAPHICAL ANALYSIS}

The type of script on the Szczerbiec was identified as late Romanesque capital with some uncial additions. W. Semkowicz paid attention to numerous inaccuracies in the inscriptions and to atypical forms of some letters, such as the L in TVLERI[T], which rather resembles the Z. Furthermore, the shape of the E was unusual, as the middle stroke was shorter than the lower and the upper ones. He considered it as having possibly resulted from the $19^{\text {th }} \mathrm{c}$. restorations of the sword. Apart from that, he regarded the script as typical for the period and dated it to the last quarter of the $12^{\text {th }} \mathrm{c}$. (Semkowicz 2002, 501-503; see also Sadowski 1894, 78-84, 110-111; Kuczyński 1961, 566, 570-572; Ciechanowski 1965, 48-51, 86; Lileyko 1987, 69, 77). He noted with right, however, that the epigraphic script evolved much slower than that on soft material. Therefore, its forms were especially prone to a longer duration (Semkowicz 2002, 471-472). Following this remark, J. P. Sobolewski assumed that on epigraphical grounds the Szczerbiec may be broadly dated to the late $12^{\text {th }}$-first half of the $13^{\text {th }}$ c. (Sobolewski 1998, 71-73; see also Nadolski 1968, 118-120).

Some analogies to the type of script on the Szczerbiec were suggested. Several scholars pointed to the paten of Duke Mieszko Stary (the Old) of Great Poland from the end of the $12^{\text {th }}$ c. (Semkowicz 2002, 504; Kuczyński 1961, 570-572; Haisig 1963, 219; Kürbisówna 1965, 273-274). Following this assumption, W. Semkowicz considered the Szczerbiec to have originally been related to Duke Bolesław (died 1195), the son of Duke Mieszko Stary (Semkowicz 2002, 503). M. Gumowski, on the other hand, proposed the chalice and the paten of Duke Konrad of Masovia (dated to c. 1250), thus dating the sword to the first half of the $13^{\text {th }}$ c. (Gumowski 1959, 12-15).

A comparison of types of script would rather confirm the first assumption. On the other hand, analogies to the Szczerbiec script may be found both on artefacts from the mid- $13^{\text {th }}$ c., such as the afore-mentioned chalice and the paten from Werben (e.g., considerably shorter middle strokes in the E, a similar manner of writing the T) (Fuhrmann 2001, 88-109, figs. $1-13,188-189$, Cat. No. 15 and 16$)$, and on those from the late $12^{\text {th }}$ c., such as the evangeliary from the monastery of St Godehard in Hildesheim (e.g., the T) (Brandt 1995, 512-516) (for the epigrapical analysis see fig. 39 A-E). It seems, therefore, that a date of the late $12^{\text {th }}$-c. 1250 is all that can be said based on epigraphical grounds.

\section{STYLISTIC ANALYSIS}

Concerning possible analogies in the ornamentation program between the Szczerbiec and other works of art, the paten of Duke Mieszko Stary was pointed out again. At this occasion, the role of cultural influences from Lorraine was underlined and it was suggested that the goldsmith Konrad who made the paten may have come from there (Semkowicz 2002, 550 ff; Walicki 1968, 279-280, 300-301; Derwich 1995, 142; on family relations between Duke Mieszko and Lorraine see also Krzyżaniakowa 1975, 182-186 and Świeżawski 2006, 51; on the paten see also, e.g., Bochnak and Pagaczewski 1959, 22-26; Walicki 1968, 279-280, figs. 1058-1061; Świechowski 1983, 76, fig. 224; Świechowski and Świechowska 2004, 338-340; Gradowski and Pielas 2006, 277, No. 197/13)

On the other hand, the paten and the chalice of Duke Konrad of Masovia were suggested. This, together with putative analogies concerning the type of script, would link the weapon to Konrad's son Duke Bolesław (died 1248), the paternal uncle of Władysław Łokietek (Sadowski 1894, 101; Gumowski 1959, 12-14; Askanas 1991, 60-65; on the paten and the chalice of 


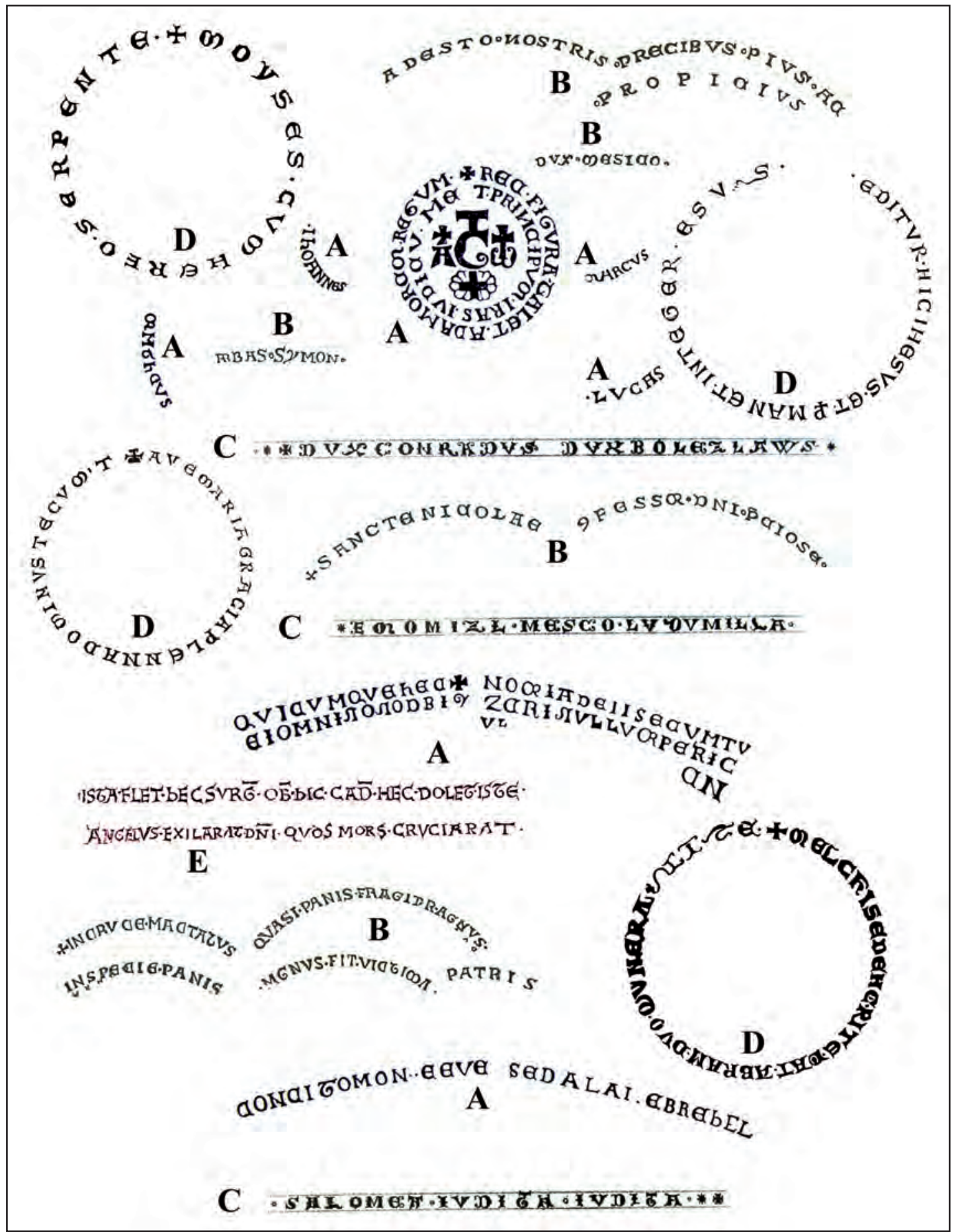

Figure 39. Comparison of the type of script between the Szczerbiec and selected other artefacts. A - the Szczerbiec. B - the paten of Duke Mieszko Stary (dated to 1193-1202). After Ciechanowski 1965, 135, fig. 27. C - the chalice of Duke Konrad of Masovia (dated to c. 1250). After Ciechanowski 1965, 144, fig. 38. D - the chalice and the patene from Werben (1251-1263?). After Fuhrmann 2001, 89, fig. 1, 91, fig. 4, 94, fig. 8, 96, fig. 10. E - the evangeliary from the monastery of St Godehard in Hildesheim (c. 1170-1180). After Brandt 1995a, 515. 
Konrad see also Jasiński 1997, 283-297). An additional argument was that the paten and the chalice of Konrad, although being stylistically related to Lower Saxony, were possibly manufactured in Masovia (Bochnak and Pagaczewski 1959, 26-32, 48, 50; Walicki 1968, 281-282, figs. XXIV, 1064-1071; Świechowski 1983, 76, figs. 225-226; Świechowski and Świechowska 2004, 340-341).

A comparison of the Szczerbiec to these two artefacts in fact reveals some similarities (see fig. 40 A-C). There are, on the other hand, some notable differences. The hilt of the Szczerbiec is coveted with gold plates, while the other artefacts are made of silver, with some gilding on the paten of Duke Mieszko. Furthermore, the two artefacts display no linear cuts in the background, nor are the sihouettes surrounded with engraved lines. This implies that a search for stylistic analogies must include a much broader comparative background.

Attention is first drawn to a diadem from the Płock Cathedral, originally being a wedding crown of Hungarian Duchess Jolenta (died after 1304), since 1256-1258 the wife of Duke Bolesław Pobożny. In this case it is of interest that it is also made of gold-coveted silver. Furthermore, a combination of gold figural representations against the black nielloed background (as it is the case with the Szczerbiec) is noteworthy. The diadem itself may be either of Mosan or Hungarian-Venetian origin. It is worth mentioning that there are some notable similarities between the diadem of Duchess Jolenta and the crown of her aunt Jolanta (died 1253), who in 1235 married Jaime I King of Aragon (died 1279). Furthermore, a very similar diadem (although made entirely of gold) was made for Jolenta's sister Kinga, the wife of Duke Bolesław Wstydliwy (the Shy) of Kraków (Bochnak and Pagaczewski 1959, 14-15; Walicki 1968, 298-299, figs. 1134-1139, III; Kovács 1974, 32-43, 61-62, No. 34-37, 38, figs. 34-37; Sachs 1984, 38-41; Lileyko 1987, 19-22, 25; Askanas 1991, 61-63; Piwowarczyk 1998, 133; Mühlemann 2000/2001, 11-13; Świechowski and Świechowska 2004, 347-348; Nowacki 2008, 286-291, 294-295; for family relations see Dworzaczek 1959, Tables 84 and 85, Jasiński 1995, 42-43, and Świeżawski 2006, 42, 57; fig. 40 D). Again, the similarities between the Szczerbiec and the diadem of Jolenta were one more argument for J. P. Sobolewski for the sword having originally been related to Duke Bolesław Pobożny (Sobolewski 1998, 91-92).

Analogies to artefacts with figural representations, which have their backgrounds filled with linear cuts or other kinds of ornament, are numerous (e.g., an early $13^{\text {th }}$ c. portable altar from Lower Saxony, see Brepohl 1987, 208, No. 73.3; the reliquary from Enger, c. 1120, see Brepohl 1987, 132, No. 32.2; the portable altar from Stavelot, c. 1160, see Mâle 1947, 161163, fig. 127, Petzold 1995, 156-157, fig. 118 and Favreau 2007, 240-242, figs. 3 and 4). It seems that more relevant analogies may be offered by artworks which display other remarkable features which can be seen on the Szczerbiec hilt, i.e., the silhouettes being surrounded with engraved lines, or the haloes of the figures being filled with wavy lines.

It has already been suggested that the Szczerbiec may bear traces of influences of the Rheno-Mosan art (e.g., Sadowski 1894, 97-101; Kuczyński 1961, 570-572; Walicki 1968, 279-280, 301). One can point to selected artefacts, such as the reliquary of St Valeria from Limoges, c. 1170/1180 (Müller 1995, 303-305), the crucifix from Limoges, c. 1200, with a remarkable halo of Christ and with an engraved line around the figure of a saint (François 1995, 305-307; see fig. 40 E), enameled plaques with the Holy Virgin and St John from Limoges, c. 1170-1190, with the same remarkable features (Robinson 2008, 126-127; see fig. $40 \mathrm{~F}$ ), as well as some further examples (Robinson 2008, 210-211, 302-303). Several artefacts from the Rheno-Mosan art sphere also display other similarities, such as the nielloed background on the reliquary of the Holy Virgin from Tournai, dated to 1205 (Lemeunier 2007b, 127, fig. 13; see fig. $40 \mathrm{G}$ ), or linear cuts in the background of the phylactery of St Martin from Namur, c. 1228 (Lemeunier 2007a, 19, fig. 6; see fig. $40 \mathrm{H}$ ). Attention is also drawn to the afore-mentioned 


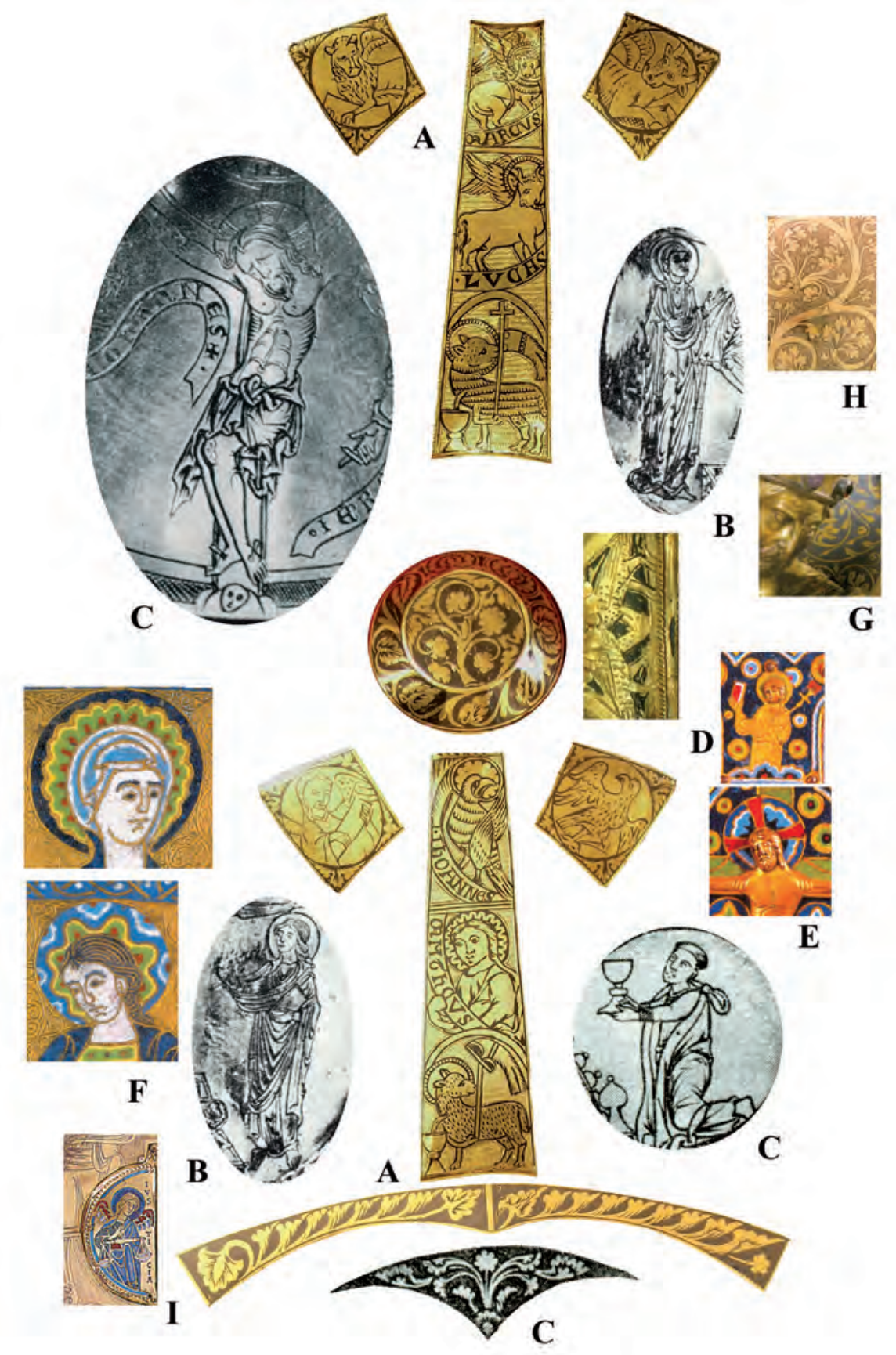

Figure 40. Comparison of the style of ornamentation between the Szczerbiec and selected other artefacts. A - the Szczerbiec. B - the paten of Duke Mieszko Stary (dated to 1193-1202). After Bochnak and Pagaczewski 1959, 24, fig. 6. C - the paten and the chalice of Duke Konrad of Masovia (dated to c. 1250). After Bochnak and Pagaczewski 1959, 29, fig. 9, 31, fig. 16. D - the diadem of Duchess Jolenta (before 1256?). Muzeum Diecezjalne in Płock. Photo G. Żabiński. E - the crucifix from Limoges, c. 1200. After François 1995, 306. F - enameled plaques with the Holy Virgin and St John from Limoges, c. 1170-1190. After Robinson 2008, 127. G - the reliquary of the Holy Virgin from Tournai, 1205. After Lemeunier 2007b, 127, fig. 13. H - the phylactery of St Martin from Namur, c. 1228. After Lemeunier 2007a, 19, fig. 6. I - the reliquary of St Gondulf (detail), c. 1165-1200, the Mosan art. After Lemeunier 2007a, 14, fig. 3. 
reliquary of St Gondulf, c. 1165-1200, with regard to similarities in the filling of the background and the haloes of the figures (Lemeunier 2007a, 14, fig. 3; see fig. 40 I). Again, based on stylistic grounds it seems difficult to suggest a more certain date for the Szczerbiec than the first half of the $13^{\text {th }} \mathrm{c}$. Although it would perhaps be difficult to directly relate the sword to the Rheno-Mosan art sphere, some analogies concerning the details of ornamentation are noteworthy.

\section{TYPOCHRONOLOGICAL ANALYSIS}

A modern typochronological analysis of the Szczerbiec was first carried out by A. Nadolski. He classified the weapon as Oakeshott's Type XII, I, 6. He considered blades of Type XII to be most widespread between c. 1170 to c. 1130, while pommels of Type I (although already known in the early Middle Ages), became more widespread after c. 1250. As in his opinion crosspieces of Type 6 are generally related to the $13^{\text {th }}$ c., he dated the Szczerbiec to the second half of the $13^{\text {th }} \mathrm{c}$. In his earlier work he related the weapon to Władysław Lokietek's paternal uncle Duke Bolesław of Cuiavia, chiefly based on genealogical grounds, while in his later paper he rather attributed the Szczerbiec to Duke Bolesław Pobożny (Nadolski 1968; Nadolski 1992). A. Nadolski also pointed to some possible analogies: the sword of Santa Casilda (XII, G, 6, c. 1300), the sword of Sancho IV el Bravo (XII, I, 6, before 1298), and the coronation sword of Emperor Friedrich II (XI/XII, J/J1, 1, before 1220), with regard to the rectangular cross-section of the grip. Furthermore, he noted several analogies in the works of art, with particular reference to the Cantigas de Santa Maria of Alfonso X of Castille and Léon (12521284) (Nadolski 1968, 109, figs. 5 and 6, 120-121; Nadolski 1992, 220-222, figs. 74-75, 224, fig. 77; see also Żygulski 1975, 90-92). At this occassion, Prof. Żygulski also stressed the fact of atypicality of the Szczerbiec with regard to the lavishness of its ornamentation and inscriptions (Żygulski 1975, 91-92).

Based on the data provided by E. Oakeshott, it can be said that blades of Type XII, having appeared c. 950, were most widespread from the $12^{\text {th }}$ to the mid. $14^{\text {th }}$ c. (Oakeshott 1964, 3840, figs. 14-15 and 18, Plates 3C, 3D, 6A, 8B, 8C; Oakeshott 2000a, 67, 74-76, 79, 81-83, 85-87). Type I pommels appear already before 1100, but they seem to have become most widespread between c. 1250 and c. 1350 (Oakeshott 1964, 51, fig. 28, 96; Oakeshott 2000a, 31, $34,60,62,101,103,106-107,111-112,128,148,151,155,174,181,184,189-190,224$, fig. 10, 229, fig. 23, 261-266; Oakeshott 2000b, 68, 76, fig. 69a, 93, fig. 80). Type 6 crosspieces, having originated in the late $11^{\text {th }}$ c., became more widespread after c. 1200 and they generally appear up to c. 1350 (Oakeshott 1964, 51, fig. 25, 53, fig. 27, 115-116, fig. 94-97; Oakeshott 2000a, 119, 125, 150, 156, 160, 176, 200, 228, fig. 22, 229, fig. 25, 230; Oakeshott 2000b, 59, fig. 55). Concerning the I, 6 combination, they seem to have been most popular between c. 1250-c. 1350 (Oakeshott 1964, 51-53, figs. 25 and 27, 133-134, fig. 118; Oakeshott 2000a, 119, 125, 176, 230; Oakeshott 2000b, 93-94, fig. 82, 114, fig. 96, 120-121, fig. 102).

A closer inspection of archaeological finds from Central and Southern Europe (Poland, East Germany, Bohemia, Slovakia, Hungary, Romania, former Yugoslavia and Bulgaria, based on data provided by Głosek 1984 and Aleksić 2007) revealed 167 swords altogether, which belong to any of the afore-mentioned types (i.e., blades of Type XI or XII, pommels of Type I and its variations, crosspieces of Type 6 and its variations). There were 68 swords with blade Type XII, dated to between 1100 and the early $15^{\text {th }}$ c., with 58 of them falling into the period of c. 1200-1325). They were usually associated with pommels of Type I and variations (25), H (7) B (6) and A (6), and with crosspieces of Type 1 and 1a (33). In 6 cases only they were associated with Type 6/6a crosspieces. Pommels of Type I and variations appeared in 97 cases and they 
were dated to c. 1150-1500, with most of them coming from the period of c. 1200-1350 (72). There were 31 crosspieces of Type 6 and variations, being generally dated to c. 900-c. 1500, with a more notable concentration (20 cases) in the period between 1300 and c. 1450 .

In 7 cases blades of Type XI or XII were associated with crosspieces of Type 6 or 6 a (dated to c. $1100-1250$, with one case dated to c. 1350 -early $15^{\text {th }}$ c.). In 26 cases such blades appeared together with pommels of Type I - 13 cases were generally dated to c. 1200-1300, while 9 fell into the period of c. 1250-1325. Although blades of Type XI or XII were associated with pommels of Type I or crosspieces of Type 6 in 23 cases, a combination of a Type I pommel and a Type 6 crosspiece appeared only twice, in the case of the Szczerbiec and a c. 1300-1350 Type XVI, I, 6 sword from Bulgaria (Aleksić 2007, 161, No. 203). Most significantly, a XII, I, 6 combination occurred only once and it was for the Szczerbiec. Although M. Aleksić suggested one more sword (from Vrbitsa in Bulgaria, c. 1150-1250, classified as XII/Xa?, I, 6, see Aleksić 2007, 162, No. 197), it seems that this weapon rather belongs to Type XI/XII, H, 6.

J. P. Sobolewski carried out a similar analysis, searching for swords with blades of Type XII and pommels of Type I or crosspieces of Type 6/6a, based on the data of M. Głosek for Poland, East Germany, Bohemia, Slovakia and Hungary. He identified 20 swords altogether, with most of them being dated to c. 1200-after 1300. As the majority of such swords were found in North-Western Poland and North-Western Germany (with an absence of Type 6/6a crosspieces in Brandenburg and Pomerania), he considered this as one more argument for Duke Bolesław Pobożny of Great Poland as the original owner of the Szczerbiec (Sobolewski 1998, 75-77).

This analysis merits some criticism. Apart from the fact that the place of find and the place of origin may be two completely different things (of which J. P. Sobolewski was fully aware), it must be underlined that the closest typological analogies of the Szczerbiec do not come from Central Europe. Furthermore, in contrast to the opinion of A. Nadolski, it seems that the typological analysis rather broadens than narrows the dating of the Szczerbiec. Based on it, it may be dated to before 1250 -c. 1325. It must be underlined that this fits into the dating of the sword on epigraphic and stylistic grounds, which suggest the first half of the $13^{\text {th }}$ c. At this occasion, it is worth to mention the opinion of D. Nicolle, who dated the sword to to c. 1225-1250 (Nicolle 1999, 333, No. 921, 529, fig. 921; Nicolle 1988a, No. 1131, 421; Nicolle 1988b, No. 1131, 855).

In order to give additional argument for this possible earlier dating, some analogies may be pointed out. Attention is drawn to the so-called sword of St Maurice from Torino (Type XII, A, 6), which may be dated to the late $12^{\text {th }}$-early $13^{\text {th }} \mathrm{c}$. (Laking $1920,85-88$, fig. 7; Oakeshott 1964, 38-39; see fig. 41). Of an even earlier date is the depiction of a sword (perhaps Type - , I, 6) from a mosaic in the Monreale Cathedral in Sicily, dated to c. 1180-1190. Interestingly, the weapons depicted on that mosaic reveal strong Byzantine features (Nicolle 1999, 296, No. 696o, 494, fig. 696o; see fig. 42). Concerning the famous Bible of Maciejowski, dated to c. 1250 , most blades seem to fit into Type XII, while most pommels tend to belong to Type G. Although most crosspieces

Figure 41. So-called sword of St Maurice from Torino (XII, A, 6), late 12thearly 13th c. After Laking 1920, 86, fig. 7.

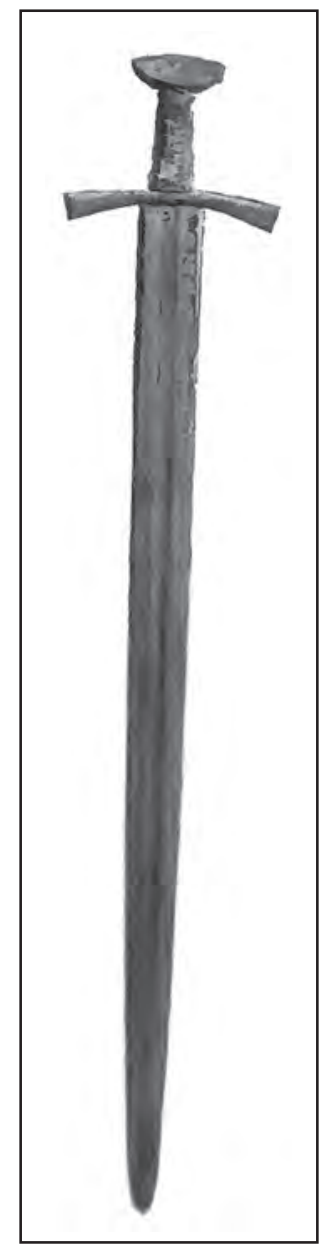




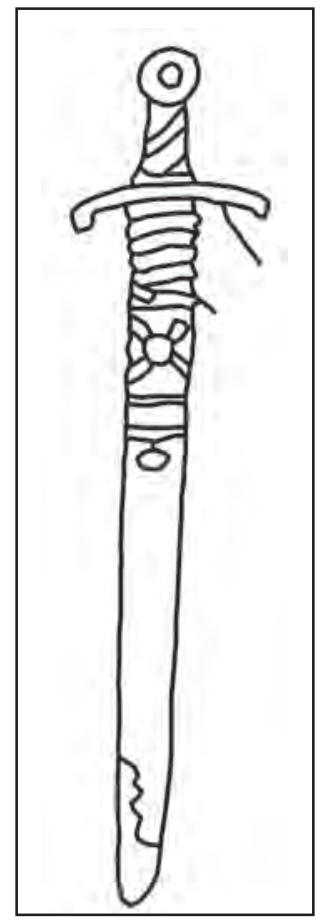

must be paid to ornamented swords to be absolutely unowner on the sword, a given person is Figure 42. Sword from a mosaic in the Monreale Cathedral, Sicily (-, I, 6), c. 1180-1190. Drawing by G. Żabiński after Nicolle 1999, 494, fig. 6960.

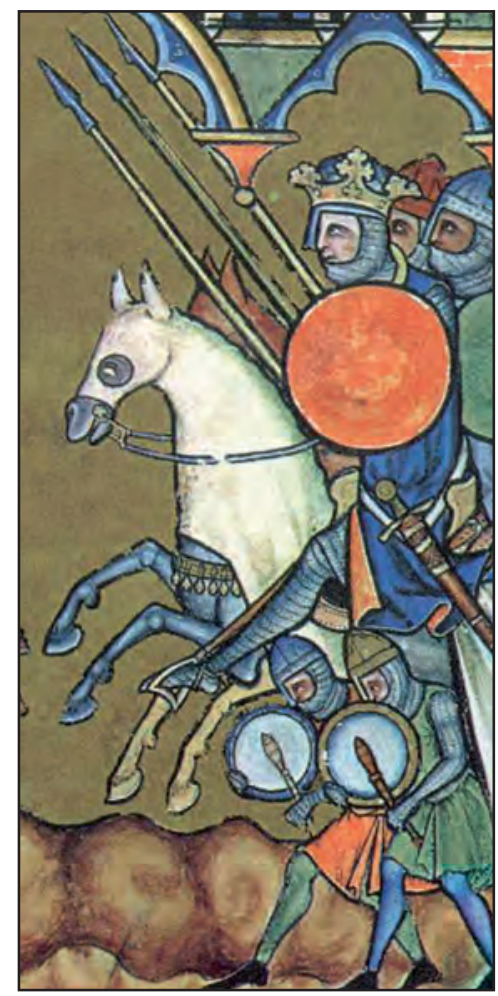

Figure 43. Sword (Type - , I, 6) in the Bible of Maciejowski, c. 1250. After Bible of Maciejowski 1975, Scene 70, 9v.

seem to conform to Type 3, there are some possible examples of Type 6. There is even one example of a hilt of possibly Type I, 6 , with the blade being shown in the scabbard (Bible of Maciejowski 1975, Scene 70, $9 v$; see fig. 43). Finally, although it concerns a weapon from the second half of the $13^{\text {th }}$ c., it is worth mentioning a sword (Type - , I/J, 6) from the Crucifixion scene (1259-1260) on the pulpit in the Pisa Cathedral Baptistery (see fig. 44).

In the search for closer analogies to the Szczerbiec, attention some general features of European of the period. First of all, it seems common to place the name of the as the relation of the weapon to usually expressed by placing the coat of arms on the pommel. If inscriptions are present, they are usually much shorter and of invocatory nature. Grips are usually made of organic material, with some individual elements being made of metal. Their cross-sections are usually oval and they are hardly ornamented in such a lavish manner as the Szczerbiec is. Some selected examples may include:

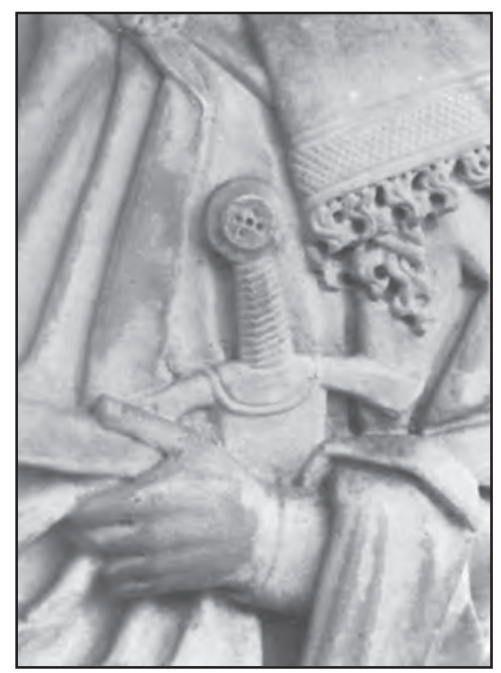

- the so-called sword of St Maurice - the Imperial coronation sword (XI, D, 1, dated to c. 1050-1120). The gilded pommel is ornamented with two coats of arms: the Imperial one and the personal one of Emperor Otto IV (1198-1218. It also bears the inscription: BENEDICTVS. DO[MINV]S. DE[V]S. QVI. DOCET MANV[S] - «Blessed is Lord God Who Trains the Hands» (from Psalm 144). The gilded crosspiece bears the inscription: CRISTVS. VINCIT. CRISTVS. REIGNAT. CRIST[VS] INPERAT - «Christ wins, Christ rules, Christ governs.» (Oakeshott 2000a, 56; Luckhardt 1995, 344; Seitz 1965, 138-142, fig. 82)

Figure 44. Sword (Type - , I/J, 6) from the Crucifixion scene (12591260) on the pulpit in the Pisa Cathedral Baptistery, by Nicola Pisano. After Seidel 2005, 282, fig. 13. 


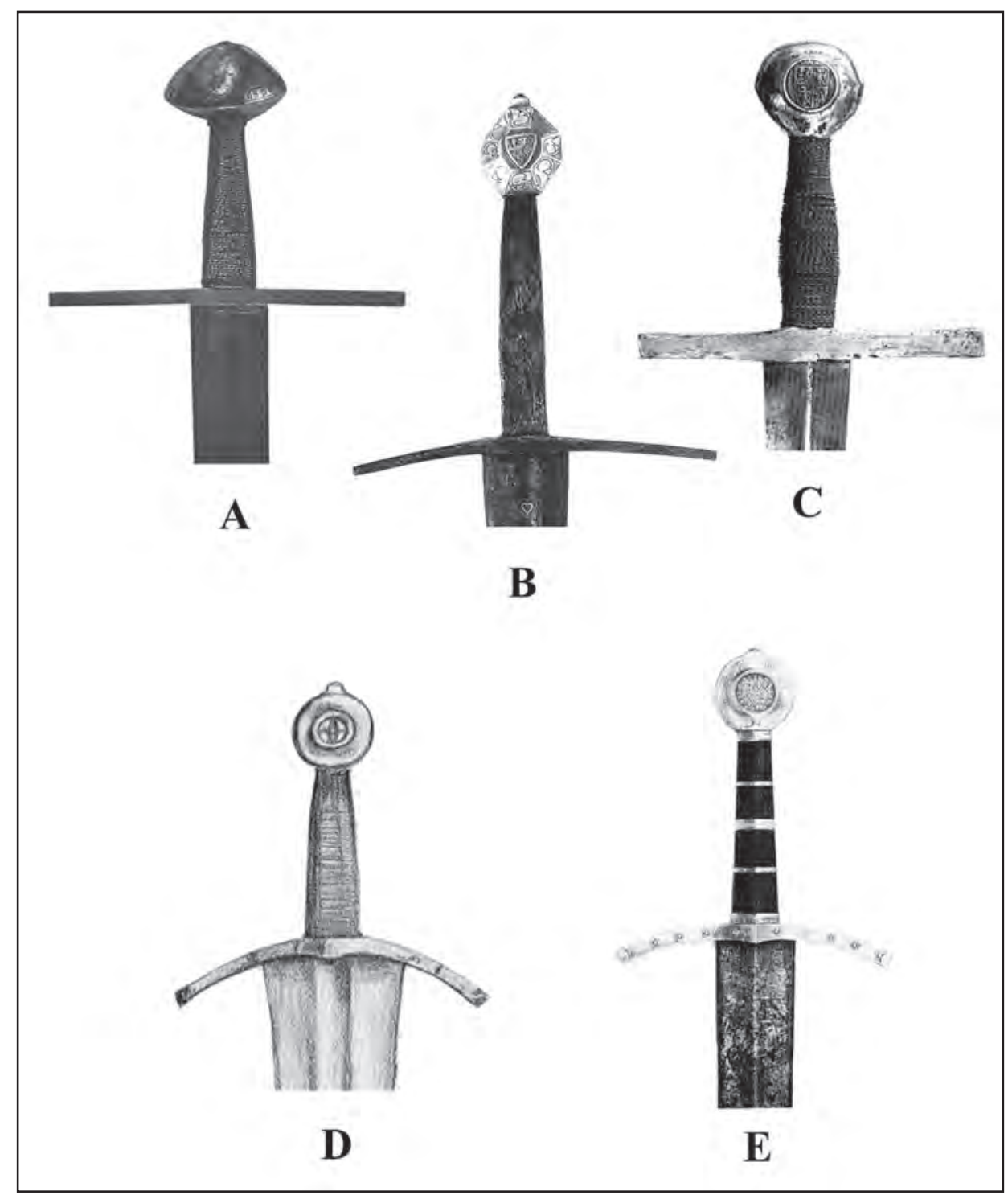

Figure 45. Ornamented swords: A - the so-called sword of St Maurice - the Imperial coronation sword (XI, D, 1, dated to c. 1050-1120). After Seitz 1965, 140, fig. 82b. B - the so-called sword of Konrad von Thüringen Grand Master of the Teutonic Order (1239-1241) (Type XIIa, I1, 1). A more probable dating is c. 1350-1450. After Huther 2007, fig. after p. 87. C - the sword of Don Juan El de Tarifa (Type XIIIb, I, 2, before 1319). After Oakeshott 2000a, 110. $\mathrm{D}$ - the sword probably coming from the Chartres Cathedral, maybe originally belonging to King Philippe IV le Bel of France (Type XIV, K, 7, c. 1300-1350). After Oakeshott 2000a, 124. E - the sword of King Edward III of England (Type XVIIIa, K, 6, c. 1348-1350). After Oakeshott 2000a, 268.

- the so-called sword of Konrad von Thüringen Grand Master of the Teutonic Order (1239-1241) (Type XIIa, I1, 1). The bronze pommel is ornamented with two coats of arms: the Lion and the Eagle, while the blade bears a Passau wolf, and the marks of a heart and a cross (Huther 2007, 85; Oakeshott 2000a, 94; Müller and Kölling 1981, 
159, fig. 9, 362, No. 9). This sword is, however, more probably dated to c. 1350-1450 (Głosek 1984, 74-76, 152-153, No. 198, fig. XXXII.3; Aleksić 2007, 52)

- the sword of Don Juan El de Tarifa, brother of King Sancho IV (Type XIIIb, I, 2, before 1319). The pommel, coveted with gilded silver, is ornamented with a heraldic disc (Oakeshott 2000a, 109-110; Bruhn-Hoffmeyer 1982, 59-62, fig. 10-11)

- the sword coming perhaps from the Chartres Cathedral and possibly belonging to King Philippe IV le Bel of France (Type XIV, K, 7, c. 1300-1350). The iron pommel is coveted with gold, with a cross-shaped piece of cloth under a rock crystal plaque. The blade bears the inscription: NULLA DE VIRTUTIBUS TUIS MAJOR CLEMENTIA EST «None of Your Virtues is greater than Mercy» (Oakeshott 2000a, 124)

- the sword of King Edward III of England (Type XVIIIa, K, 6, c. 1348-1350). The goldcoveted iron pommel is ornamented with rosettes and a heraldic disc is notable in its central part. On the other side there is a chalcedony disc with a piece of cloth underneath (a relic?). The gold-coveted iron crosspiece is also ornamented with rosettes. The blade bears a motto of the Garter (Oakeshott 2000a, 268 ff) (figs. 45A-E)

Furthermore, attention is drawn to a Type XII, G, 1 sword (c. 1150-1200) from the Kunstgewerbemuseum in Düsseldorf, due to lavish inscriptions: + QUI FALSITATE VIVIT ANIMAM OCCIDIT FALSUS IN ORE CARET HONORE +, or «Who lives in falsehood, slays his soul. Whose speech is false, that is without honour» and + QUI EST HILARIS DATOR, HUNC AMAT SALVATOR OMNIS AVARUS NULLI EST CARUS +, which stands for "Who is a cheerful giver, the Saviour loves him. Greedy man is dear to no one.» In this case, however, the inscriptions were placed not on the hilt, but on the blade (Oakeshott 2002, 40; Oakeshott 2000a, 82; a letter from Dr Alfred Geibig from 12 November 2008).

The Szczerbiec in fact seems to be rather atypical against the background of these examples. The first issue to be dealt with is the rectangular cross-section of the grip. At this occasion, the afore-mentioned reservation of the front plates being of possibly later origin must be remembered. On the other hand, even in such a case the putative original grip in all probability had a similar construction. As dealt with above, the non-existent side plate with the title of Duke Bolesław was most possibly original, as any later addition would have rather stressed the Royal and not Ducal title. The rectangular shape of that plate therefore required a similar form of other grip plates as well.

Concerning swords with a similar form of the grip, attention is first of all drawn to the coronation sword of Emperor Friedrich II (this was already noted by Żygulski 1975, 92 and Nadolski 1992, 220-222, fig. 74). Belonging to Type XI/XII, J/J1, 1, the sword was made before 1220 in Palermo. The original pommel was replaced with a new one by Karl IV, with regard to his Bohemian and German royal coronations (1346-1347). The entire hilt is coveted with metal and is ornamented in a Byzantine-Oriental style. It was considered typical for the courtly style of Norman rulers of Sicilly, who often employed Arab craftsmen (Thomas, Gamber, and Schedelman 1981, fig. 1; Bruhn-Hoffmeyer 1954, 24, No. 134, fig. XVII; Seitz 1965, 148, fig. 88; Głosek 1984, 176-177, No. 489, fig. XX; Nicolle 1988a, 436, No. 1178; Nicolle 1988b, 868, fig. 1178; Nicolle 1999, 178, No. 450, 439, fig. 450; see also Żygulski 1975, 91, fig. 43d; see fig. 46).

The rectangular cross-section of the grip seems to frequently appear on Arab swords. This is well visible for swords from the Mediterranean realm, with special reference to the Iberian Peninsula and Southern Italy, as the two areas were a melting pot of Christian and Moslem influences. Some selected examples may include: 


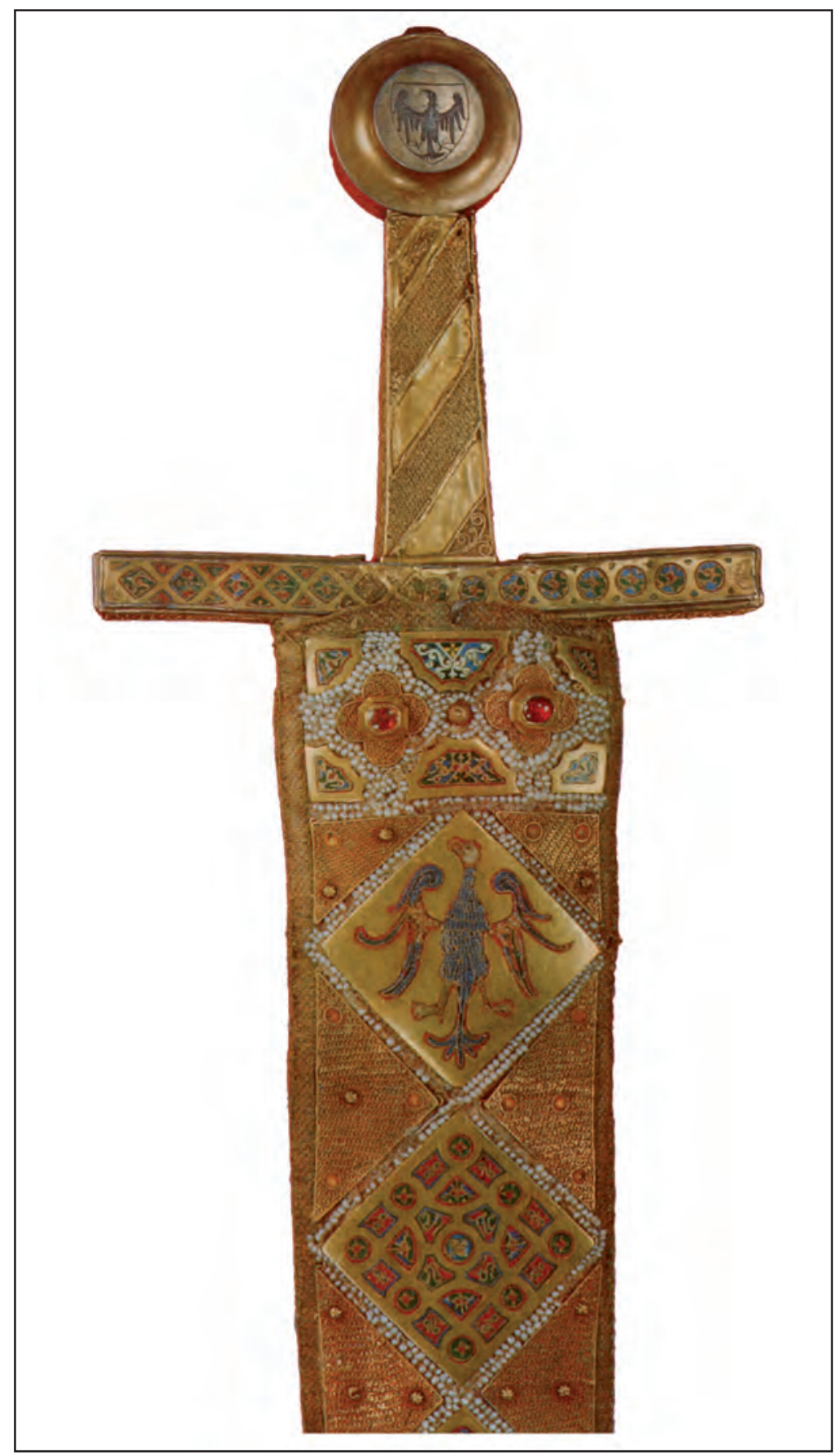

Figure 46. Sword of Emperor Friedrich II (Type XI/XII, J/J1, 1, before 1220). After Thomas, Gamber and Schedelman 1981, fig. 1.

- the bronze pommel and the crosspiece of a sword from Egypt $\left(10^{\text {th }}-11^{\text {th }} \mathrm{c}\right.$.), where the shape of the grip is implied by the form of the preserved parts of the hilt. Rich ornaments and quotations from al-Quran are also noteworthy (Nicolle 2002, 178-179, fig. 114; Nicolle 1988a, 203, No. 517; Nicolle 1988b, 736, fig. 517) 
- the jineta sword of a Moorish convertite from a late $13^{\text {th }}$ c. sculpture in the Santo Domingo de Silos Monastery (Castille) (Nicolle 1999, 156, No. 394, 428, fig. 394; Nicolle 1988a, 261, No. 651; Nicolle 1988b, 763, fig. 651)

- the Type XII, L, 6 sword of King Fernando III (San Fernando) of Castille (1223-1253), being clearly related to Islamic Andalusian traditions. Interestingly, the iron pommel is coveted with gilded silver and the silver crosspiece is gilded (Nicolle 2002, 166-167, fig. 47, 184; Nicolle 1988a, 241, No 601; Nicolle 1988b, 755, fig. 601; Oakeshott 1964, 96-97, fig. 64, 124; Catalogo 1898, 203-205, fig. 199) (figs. 47A-C)

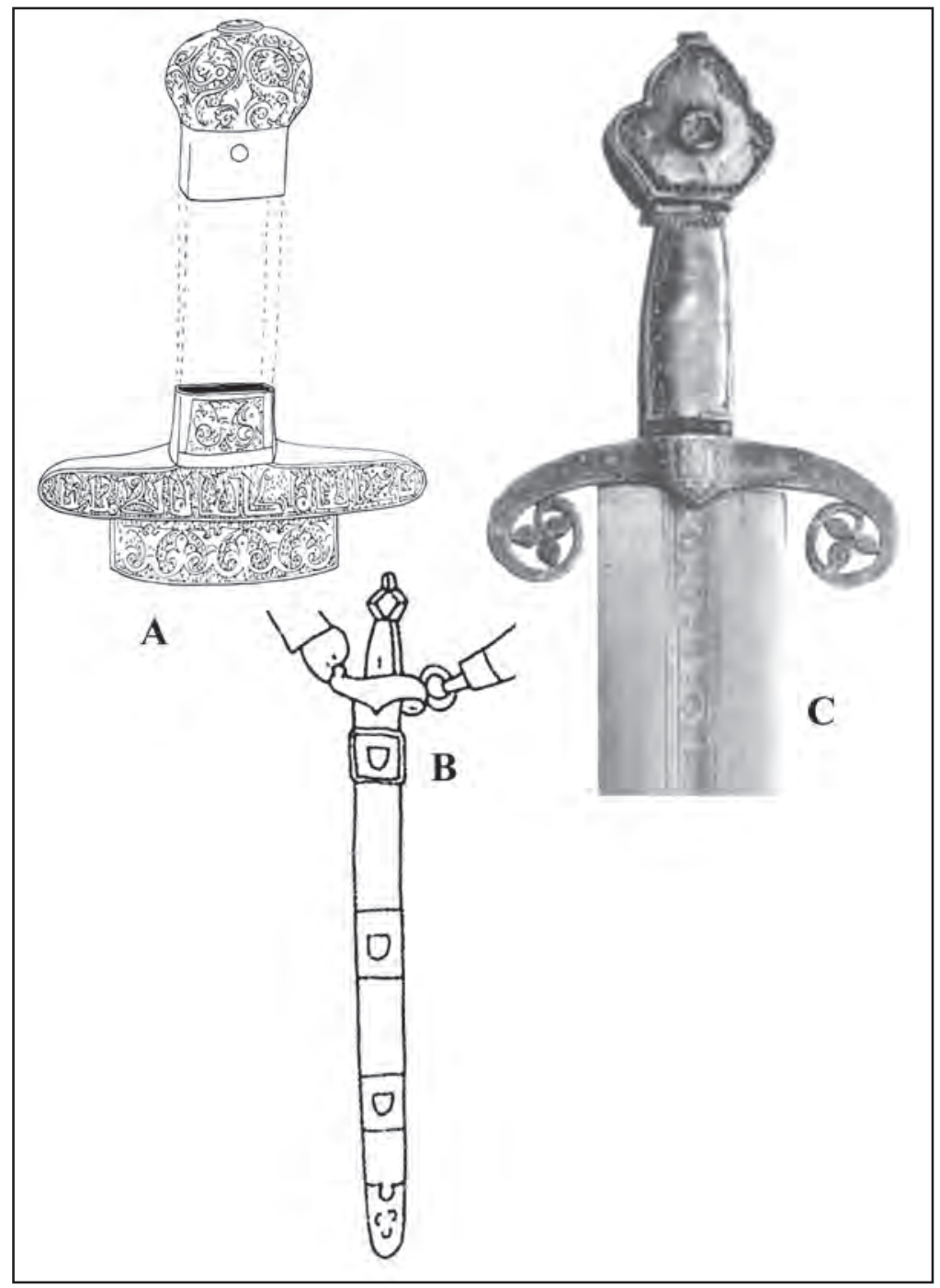

Figure 47. Mediterranean swords with grips with rectangular cross-section: A - the bronze pommel and the crosspiece of a sword from Egypt $\left(10^{\text {th }}-11^{\text {th }}\right.$ c.). After Nicolle 1988b, 736, fig. 517. B - the jineta sword of a Moorish convertite from a late 13th c. sculpture in the Santo Domingo de Silos Monastery (Castille). After Nicolle 1988b, 763, fig. 651. C - the Type XII, L, 6 sword of King Fernando III (San Fernando) of Castille (1223-1253). After Catalogo 1898, 203, fig. 119. 
Apart from the sword of Friedrich II, attention is also drawn to other swords with hilts being entirely covered with metal. The following examples can be mentioned:

- the sword from Prado del Rey in Cadiz, Type XIII, R, 11, the $14^{\text {th }}-15^{\text {th }}$ c. The metal grip (made of bronze or brass, and possibly partially gilded) is lavishly ornamented with inscriptions (Nicolle 2002, 166-167, figs. 41a-e, 170)

- the sword of the Comtés de Dreux, Type XII, J, 6, c. 1240-1309. The entire hilt is made of copper and the grip is additionally gilded and wrapped with silver wire. The crosspiece and the gilded bronze rings are inscribed with Gothic minuscule inscriptions COLLIGE PER ME REGE SUM [MUM?] and MEDIO REGE PUNGE PER IMUM. The blade bears the following letters: $\mathrm{H} \mathrm{E} \mathrm{T} \mathrm{E} \mathrm{E} \mathrm{T} \mathrm{H}$, apart from vestiges of an Arab inscription (as the sword was kept in the Alexandria Armoury after 1309). The pommel is ornamented with a gold and blue chessboard heraldic shield on the one side and there is a rock crystal or chalcedony disc on the other side. The item hidden beneath was originally interpreted by E. Oakeshott as a finger-bone, while in his latter work he considered it as a piece of an oak root. He proposed that the name of Dreux originally came from «drys» or «drui» (oak) and said that the castle of Dreux was built in a location of an ancient Druidic oak. He even assumed that the sword may have had some Templar connections as this order was supported

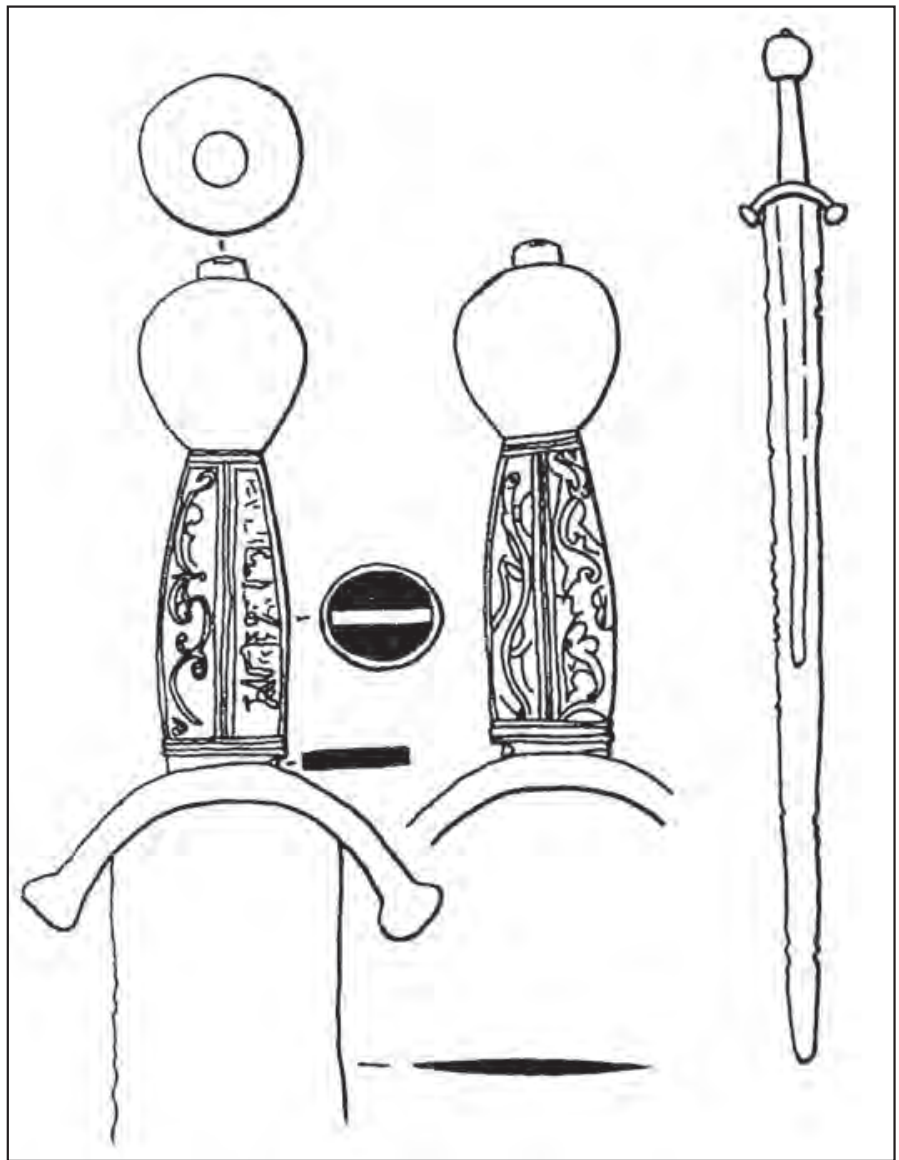

Figure 48. Sword from Prado del Rey in Cadiz, Type XIII, R, 11, the $14^{\text {th }}-15^{\text {th }}$ c. After Nicolle 2002, 167, figs. 41a-e. by the Comtés of Dreux

(Oakeshott 2000a, 86; Oakeshott 2002, 37-44). E. Oakeshott read the hilt inscriptions as «I determine the binds of the law» and «For the law I strike,» but it seems that they are a somehow distorted version of inscriptions from croziers: COLLIGE SVSTENTA STIMULA VAGA MORBIDA LENTA and ATTRAHE PER PRIMUM MEDIO REGE PVNGE PER IMUM, which stands for «Gather, sustain and goad the stray, the ailing and the tarrying» and «First, draw, the midst, rule, the end, goad» (see, eg., Durandus $1899,113-114)$ 
- the sword from the Museo Arqueológico Nacional in Madrid (No. 2759/3), Type XII, I, 6, dated to c. 1300-1350. The hilt is made of gilded bronze and is decorated with acanthus and geometrical motives. On the one side of the pommel there is a while enamel disc with a red enamel fleur de lys. A French origin is therefore assumed for this weapon. A disc from the other side of the pommel is missing. The pommel and the crosspiece are also ornamented with the inscription AVE MARIA GRACIA PLENA DOMINUS TECUM ORA PRO NOBIS or «Hail Mary, full of grace, the Lord is with you, pray for us.» There is also an inscription on the blade, beginning with the reverse E, followed by I I I I I I and closed by the E (Bruhn-Hoffmeyer 1982, 176, fig. 65, 188; a letter of Dr Marc Gener from 29 July 2008). (figs. 48, 49 and 50).

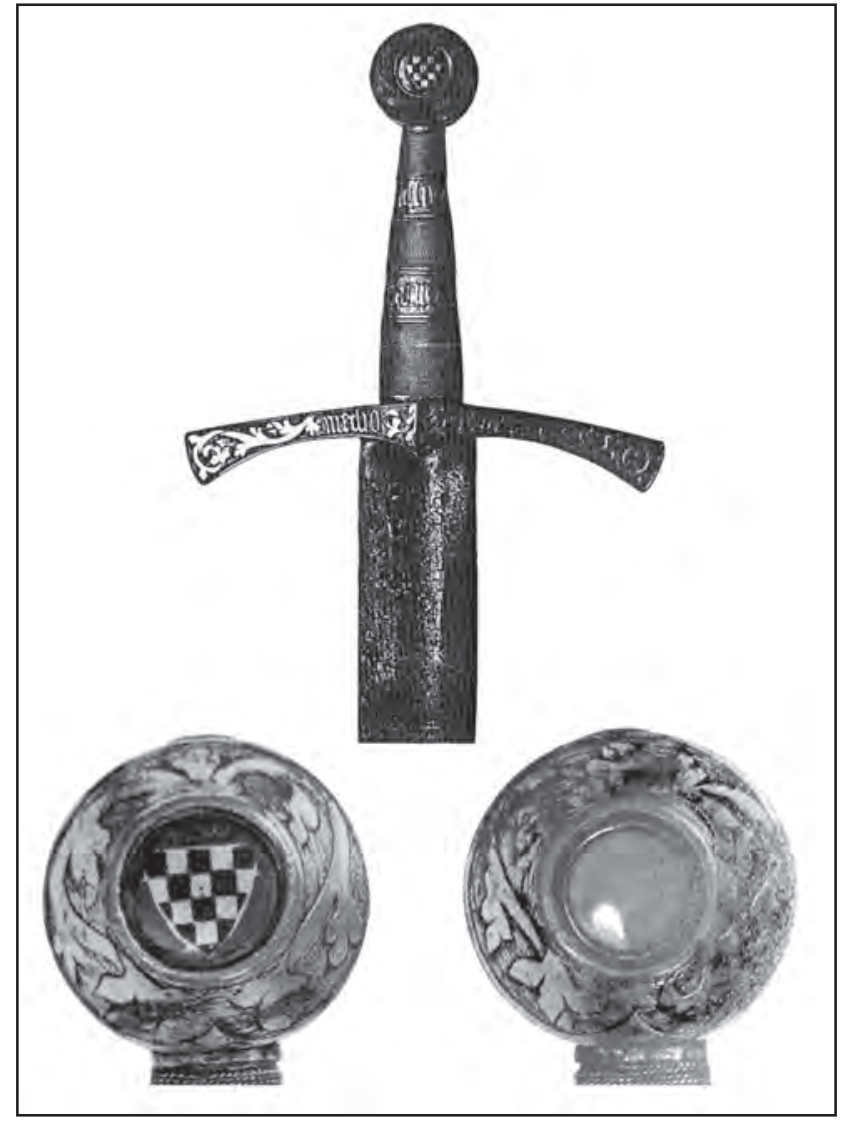

Figure 49. Sword of the Comtés de Dreux, Type XII, J, 6, c. 1240-1309. After Oakeshott 2000a, 86 (general view) and Oakeshott 2002, figs. III.4-5 (details).
Two Spanish swords, already noticed as possible analogies to the Szczerbiec, deserve a special treatment. The first one is the Type XII, I, 6 sword of King Sancho IV of Castille and Léon (died 1298). The pommel and the crosspiece are made of gold-coveted iron and are decorated with Mudéjar ornaments and Arab inscriptions. The grip is ornamented with glass discs with the coats of arms and small plaques with a chessboard motive. The grip is not exactly rectangular in its cross-section, but is slightly rounded on the narrower edges. There are some hardly legible inscriptions on the blade (Nicolle 2002, 160, 166-167, fig. 48, 180; Oakeshott 2000a, 72-73; Bruhn-Hoffmeyer 1982, 51-55, figs. 7 and 8; see also Oakeshott 1964, 3739, figs. 7 and 9, 124; Nicolle 1999, 155, No. 391, 428, fig. 391; Nicolle 1988a, 260, No. 648, s. 260; Nicolle 1988b, 763, No. 648). A small rivet hole in the fuller is interpreted as a trace of a heraldic disc or a relic (Bruhn-Hoffmeyer 1982, 55) (see fig. 51).

The other weapon is the sword of Santa Casilda (Type XII, G, 6, c. 1300) from the San Vincente mo-

nastery in Logrono. Both the iron pommel and the bronze crosspiece are coveted with gold. The wooden grip is covered with leather and additionally wrapped with riveted leather strap. The pommel is ornamented with a heraldic symbol and it bears the inscription AVE MARIA PLENA GRATIA. The inscription on the crosspiece says DIOS ES VINCENTOR EN TOD and O DIOS ES VINCENTOR EN TODO A[MEN?], which stands for «God is the Victor in everything» (Oakeshott 2000a, 84; Oakeshott 2000b, 15-16, fig. 10, 53, fig. 52; Bruhn-Hoffmeyer 1982, 63-65, fig. 12; see also Oakeshott 1964, 124-125, figs. 18 and 19C and Bruhn- 
Hoffmeyer 1954, 14, No. 7, fig. XIb) (see fig. 52). D. Nicolle proposed that the other inscription is a Latin transcription of a quotation from alQuran (Nicolle 2002, 168-169, fig. 50). Although some similar passages were found (e.g., Surah 3,150, Surah 8,40 or Surah 58,21 ), no identical quotation could be pointed out. A. Bruhn-Hoffmeyer said that it was a motto of the Nasrid rulers of Granada, also used by Christian knights in this kingdom (Bruhn-Hoffmeyer 1982, 63). Dr Marc Gener associated it with Mohammad I ibn Nasr's entering Granada in 1238 and pointed to a widespread presence of the motto in contemporary Andalusian art (a letter of Dr Marc Gener from 22 July 2008).

Based on the afore-mentioned examples some general features of Iberian sword hilts from the $13^{\text {th }}-14$ th centuries may be pointed out, such as lavish ornamentations and all-metal (or metal coveting on an organic grip core) construction (Nicolle 2002, 159, 166, 176-178). The afore-mentioned Historia Karoli Magni says that the hilt of Roland's Durendal had an ivory grip, a gold (i.e., perhaps

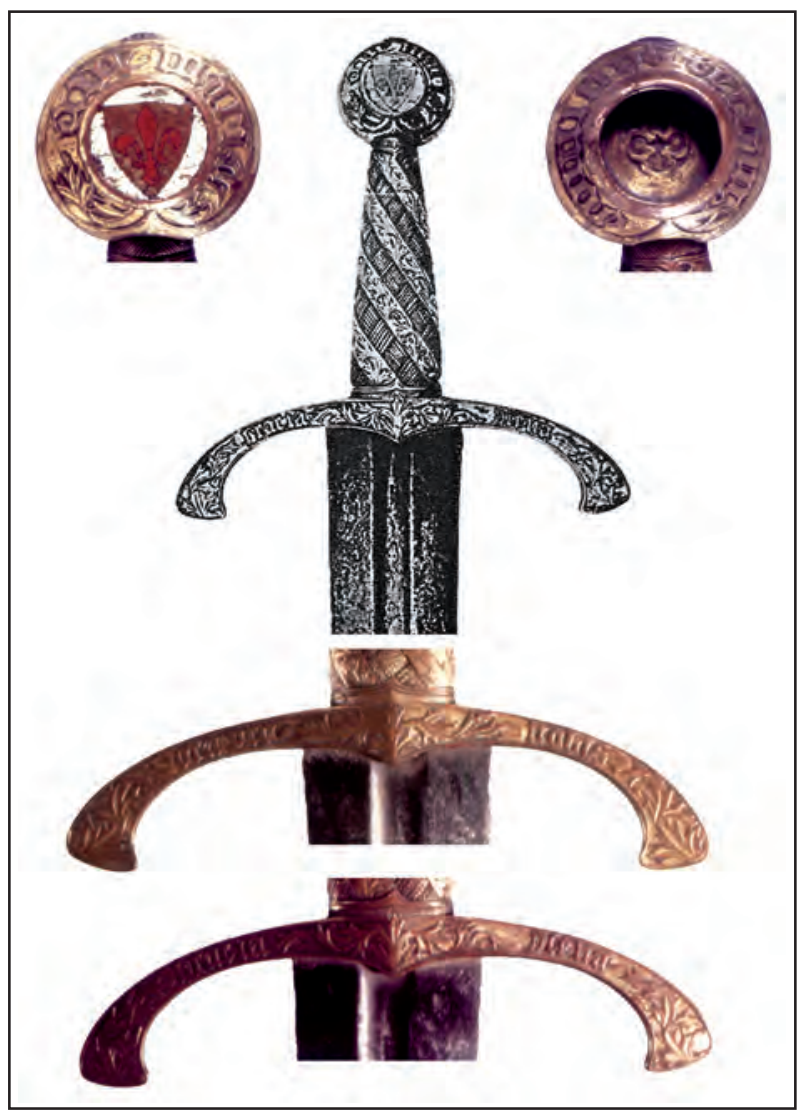

Figure 50. Sword from the Museo Arqueológico Nacional in Madrid (No. 2759/3), Type XII, I, 6, c. 1300-1350. After Bruhn-Hoffmeyer 1982, 176, fig. 65 (general view) and Museo Arqueológico Nacional in Madrid (details). .

gold-coveted) crosspiece and an ornamented beryl pommel (Turpini Historia Karoli Magni 1880, C. XXII: 45-46). A similar image is notable in the mid. $12^{\text {th }}$ c. Song of Roland, which frequently mentions swords with gold or gilded hilts (Song of Roland 1919, Christian swords: C. XXXV, v. 466, C. CVI, v. 1360, C. CXXVI, v. 1798, C. CLXXXIII, v. 2506-2508, C. CCLXXX, v. 3866, C. CCLXXXI, v. 3887, and Saracen swords: C. LIV, v. 684, C. LXXVII, v. 966). Special attention needs to be paid to the hilt of Roland's sword: apart from being made of gold or gold-coveted, it also contains numerous relics (Song of Roland 1919, C. CLXIII, v. 2344-2348). Along with preserved examples of swords with putative relics in their hilt (with special reference to the pommel), this may be another argument against the slot in the blade of the Szczerbiec having been purposefully made to accommodate a relic.

Furthermore, it seems that discoid pommels and bend crosspieces were especially widespread, based on the illuminations in the Cantigas de Santa Maria of Alfonso X of Castille and Léon (1252-1284) (see fig. 53) or other works of art (Bruhn-Hoffmeyer 1982, 69-72, figs. 1516, 191, fig. 68). Moreover, based on typochronology of side arms by Dr A. Soler del Campo, it may be assumed that «Szczerbiec-like» swords with bent crosspieces and discoid pommels appeared at a considerably early date (perhaps c. 1150) in the Iberian Peninsula (Soler del Campo 1993, 15-17, 19-20, 29, 304-306, fig. 1A-C). 


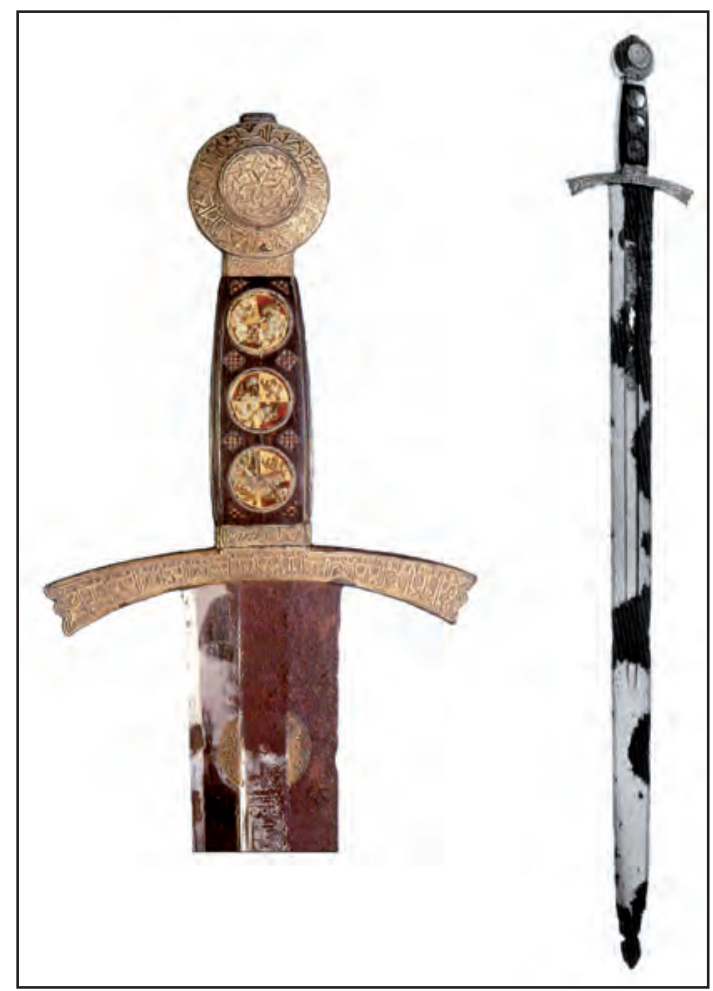

Figure 51. Sword of King Sancho IV of Castille and Léon (died 1298), Type XII, I, 6. After Oakeshott 2000a, front cover and 72..

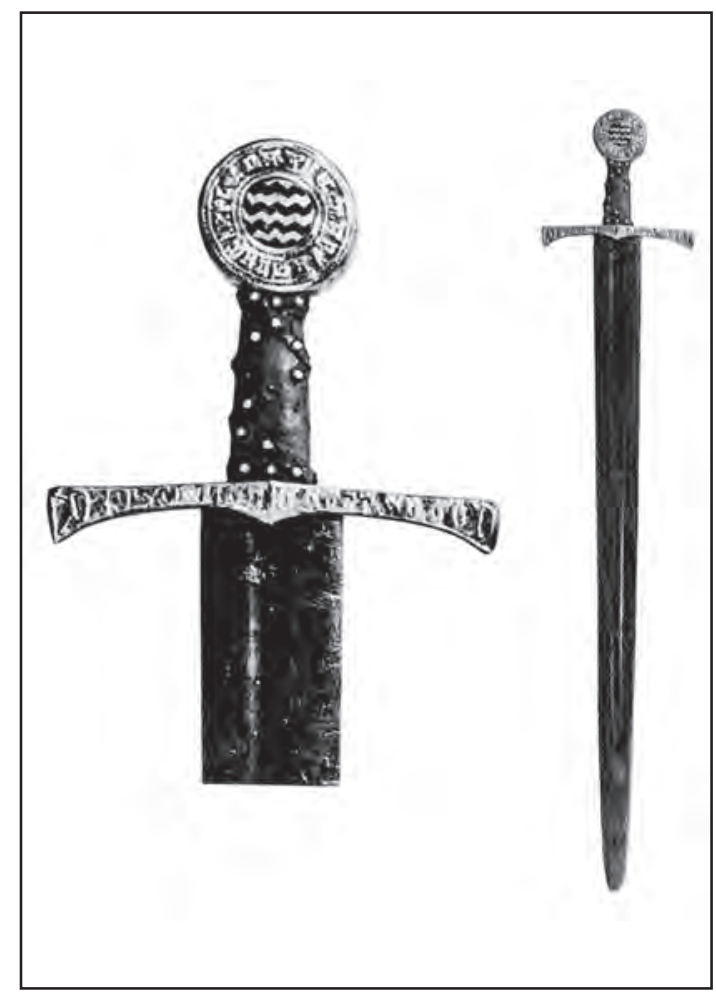

Figure 52. Sword of Santa Casilda, Type XII, G, 6, c. 1300. After Oakeshott 2000a, 84..

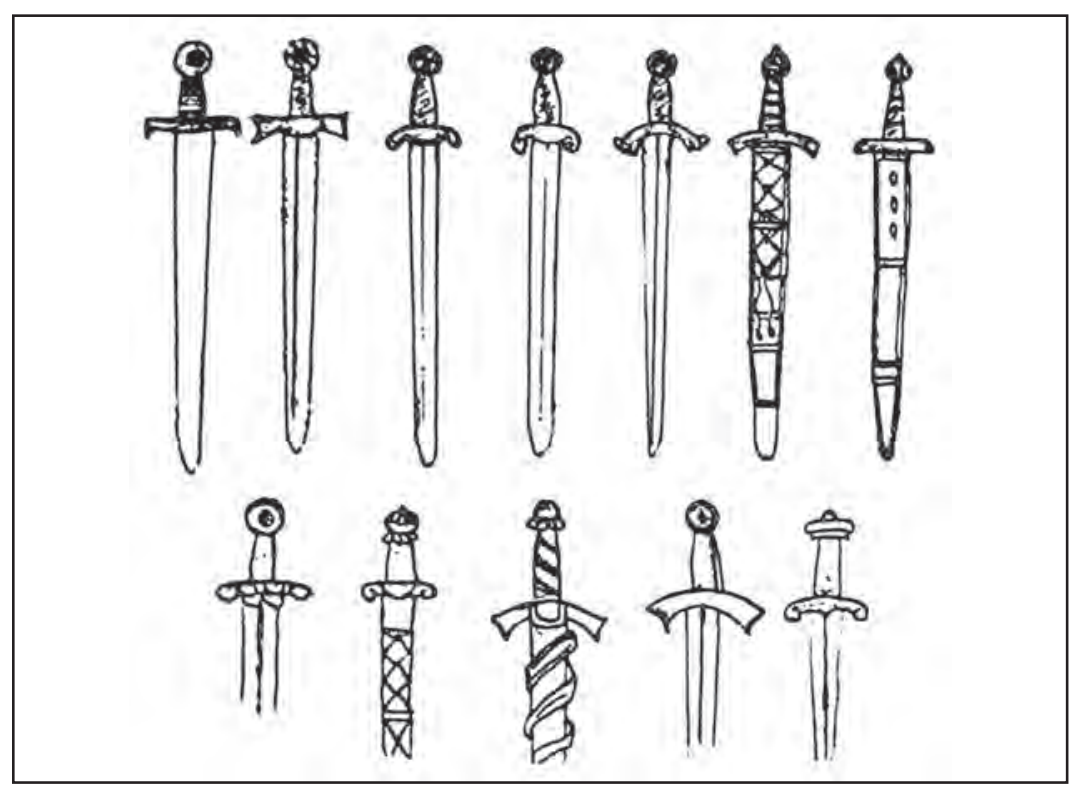

Figure 53. Swords in the Cantigas de Santa Maria of Alfonso X of Castille and Leon (1252-1284). After Bruhn-Hoffmeyer 1982, 69, fig. 15. . 


\section{PROVENANCE OF THE SZCZERBIEC}

As dealt with above, the epigraphical and stylistic grounds would suggest the first half of the $13^{\text {th }}$ c., while the typochrological analysis implies a date of before 1250-c.1325. If one assumes the authenticity of the intitulation plate with the name of Duke Bolesław of Great Poland and the first use of the Szczerbiec as the coronation sword by Władysław Łokietek in 1320 (and there is no reason so far to contradict both assumptions), a natural question arises from what ruler the Szczerbiec could come into Władysław's hands.

As mentioned, J. N. Sadowski and A. Nadolski first related the weapon to Duke Bolesław of Masovia (died 1248 with no heirs), the brother of Duke Kazimierz of Cuiavia, Władysław's Łokietek father (Sadowski 1894, 112-117; Nadolski 1992). In his later work, A. Nadolski rather suggested Duke Bolesław Pobożny - he had no son, and c. 1293 his daughter Jadwiga married Władysław Łokietek. Using his father-in-law's sword at the coronation in 1320, Władysław may have underlined his rights to Great Poland's heritage, which were questioned by his Bohemian rivals (Nadolski 1992, 223-225; Sobolewski 1998, 74; see also Rokosz 1988, 16). Furthermore, it has been suggested that the marriage may have been related to an alliance between Władysław Łokietek, his brother Kazimierz and Przemysł II of Great Poland in 1293. The alliance, being directed against the Bohemian claims to Poland, implied that Władysław would inherit Przemysł II's realm in case the latter would die with no heir (Świeżawski 2006, 49, 58; Barański 2003, 37-39; Nowacki 1997, 140-141, 171; see also Jasiński 1995, 59). Significantly, the Chronicle of Great Poland mentions that Duke Bolesław Pobożny gave Great Poland and 1200 Mark of silver to Władysław as part of the marriage contract (Chronica Poloniae Maioris 1970, c. 121: 110; the same in the Annals of Little Poland, see Rocznik małopolski 1878, 198). Although this mention is not completely trustworthy (even assuming any antenuptial negotiations before the death of Bolesław, the Great Poland's heritage was to go to his nephew Przemysł II), it may reflect a later tradition, according to which the marriage strengthened Władysław's rights to Great Poland.

An obvious reservation is that Duke Bolesław of Masovia never ruled in Great Poland. Furthermore, an assumption that Władysław Łokietek may have inherited a sword of his paternal uncle may be questioned due to tense relations between Duke Bolesław and Łokietek's father, Duke Kazimierz (see, e.g., Żmudzki 2000, 64-65). Therefore, it seems much more probable that Władysław Łokietek may have used the sword of Great Poland's origin - i.e., originally belonging to Duke Bolesław Pobożny - to underline his rights to Great Poland's heritage. As suggested above, the Szczerbiec episode of the Chronicle of Great Poland was eventually codified in the first half of the $14^{\text {th }} \mathrm{c}$. It may therefore well reflect the tradition of Władysław Łokietek, who may have purposefully represented the weapon of Duke Bolesław Pobożny as a genuine sword of King Bolesław in order to additionally legitimise his royal coronation.

Much less clear is a question how a sword with so many intriguing features may have originated in the milieu of Duke Bolesław. As mentioned, the lavishly ornamented all-metal hilt with numerous inscriptions seems to strongly suggest a Mediterranean-Iberian influence. This may also be implied by similarities between the Szczerbiec and the diadem of Duchess Jolenta, as well as by the mention of the symbols of $\mathbf{A}$ and $\boldsymbol{\Omega}$ in the Historia Karoli Magni. The story itself leads the inquiry into the world of courtly and chivalric culture. The symbols of $\mathbf{A}$ and $\boldsymbol{\Omega}$ may also have some Johannite parallels, while some stylistic features may suggest a Rheno-Mosan artistic relation. A very atypical feature is the name of the owner on the weapon (implying that the sword may have been a gift to Duke Bolesław?), and a variety of inscriptions may suggest an educated person. 
The first possible way of influence is via Hungary. As mentioned, diadems of Duchess Jolenta, the wife of Bolesław Pobożny, and her sister Duchess Kinga, bear similarities to the crown of their aunt Jolanta, the wife of Jaime I King of Aragon since 1235 (Walicki 1968, 298-299, figs. 1134-1139, III; Kovács 1974, 32-43, 61-62, No. 34-37, 38, figs. 34-37; Lileyko 1987, 19-22, 25; Askanas 1991, 61-63; Sobolewski 1998, 91-92; Ławrynowicz 2005, 108-110; Wątroba 2007, 194). Furthermore, Imre King of Hungary (1194-1204; brother of King András II, ruled 1205-1235, the grandfather of Jolenta and Kinga) married Constance, the daughter of Alfonso II King of Aragon (1162-1196) in 1198. After Imre's death, Constance married Friedrich von Hohenstaufen (future Emperor Friedrich II) in 1210 (Dworzaczek 1959, figs. 84 and 85; Engel 2001, 86, 89)

Moreover, Bolesław Pobożny’s father, Duke Władysław Odonic (died 1239), was a political exile in Hungary in 1218-1223 (Chronica Poloniae Maioris 1970, c. 58: 80; Annales Poloniae Maioris 1962, 3; see also Jasiński 1995, 38 and Świeżawski 2006, 28-29; on the crusade see, e.g., Engel 2001, 91). Although an assumption that he may have participated in András II's crusade (August 1217-January 1218) has been questioned (Gładysz 1998, 68-82; Gładysz 2002, 146-169), Duke Władysław might have anyway had enough opportunities to meet crusaders and become acquainted with various foreign patterns of weapons.

Another way may have been the presence of the military orders in Great Poland from the mid- $12^{\text {th }}$ to the late $13^{\text {th }}$ c. with special reference to Johannites and Knights Templar. As mentioned, the symbols of $\mathbf{A}$ and $\boldsymbol{\Omega}$ on the pommel of the Szczerbiec may also have some Johannite parallels. The orders received several grants from local rulers, including Duke Władysław Odonic and his sons Przemysł I and Bolesław Pobożny (for the charters see Codex Diplomaticus Maioris Poloniae 1, 1877; 6, 1982, 11, 1999), but Eastern European estates were rather insignificant part of the orders' economic hinterland and the number of knight brethren was very low there (see, e.g, Nicholson 2005, 117-121; Starnawska 2004; Starnawska 1991).

The issue of courtly culture seems to

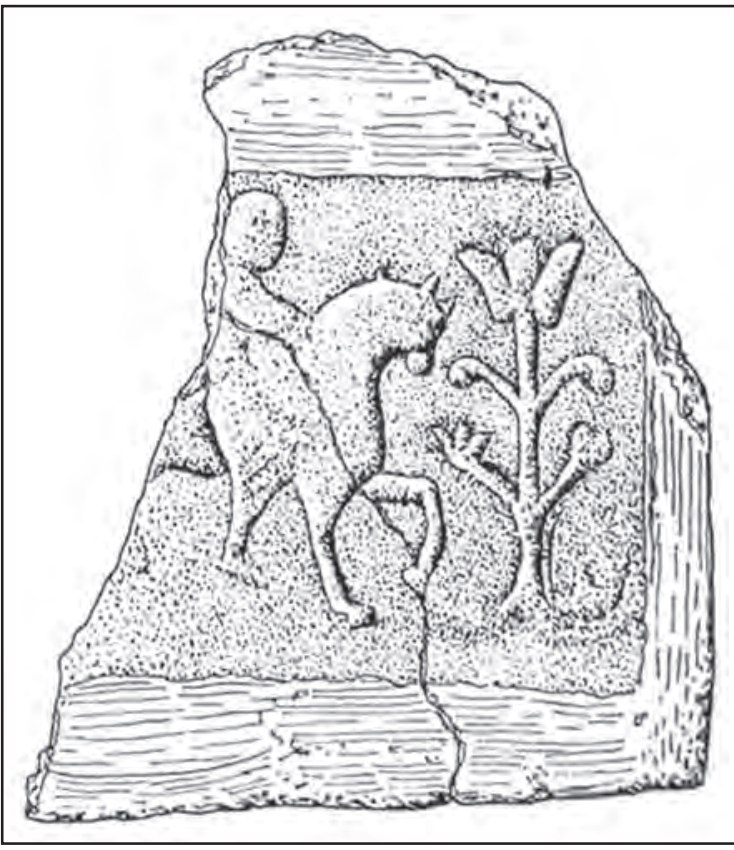

Figure 54. Tile with the Tree of Life from the Castle of Gniezno (1234-1238). After Soroka 1990, 65, fig. 7.. be more promising. Archaeological excavations at the Castle of Gniezno (built by Duke Władysław Odonic in 1234 and destroyed in 1238) revealed vestiges of a tile workshop. Preserved examples of tiles depicted scenes from chivalrous romances. Most interestingly, one of them portrayed the Tree of Life (see fig. 54) (Soroka 1990; Sawicki 1990; see also Świeżawski 2006, 199 and Wiesiołowski 1995, 132). Furthermore, based on personal names evidence, a considerable popularity of chivalrous romances (including the Song of Roland) among local nobility is proposed (Wiesiołowski 1995, 133; Wiesiołowski 1993). Duke Przemysł I was a lover of courtly literature and it is assumed that he intended to self-present himself as Lancelot (Piwowarczyk 2002, 196-197, 209, 212; Wiesiołowski 1995). Apart from that, he was also regarded as a pious and educated man, who read and 
spoke Latin (Chronica Poloniae Maioris 1970, c. 107: 107-109; Liber fundationis 1991, Book I. 10: 51; see also Świeżawski 2006, 69-70; Nowacki 1997, 44, 49).

Jewish presence in Great Poland was also strong (see, e.g., Kowalska 1998; Jurek 19921993). Of special interest is Jewish minting upon the order of the rulers, especially notable in the late $12^{\text {th }}$ c. (Jurek 1992-1993, 29-30; Kiersnowski 1988, 102-104; Kiersnowski 1964, 71-72; Gumowski 1962; Zakrzewski 1926) Although examples of such coins seem to be extremely rare, some of them display a combination of Hebrew and Christian motives (as noticed by Sobolewski 1998, 90-91). Although this issue must be approached with utmost care, one should not exclude the existence of a sort of oral tradition among them, which may have given rise to the Hebrew or Hebrew-Latin inscription on the crosspiece of the Szczerbiec.

Based on the afore-mentioned personal traits, interests and education of Duke Przemysł I, attention is drawn to an event from 24 April 1245. At that day at the Gniezno Cathedral Duke Przemysł knighted his brother Bolesław (Chronica Poloniae Maioris 1970, c. 78: 90; Annales Poloniae Maioris 1962, 8; Annals of Great Poland, see Rocznik wielkopolski 1878, 12; see also Świeżawski 2006, 37 and Piwowarczyk 2002, 196-197, 209). As giving a sword was usually part of the knighting ceremony (see, e.g., Ławrynowicz 2005, 64-65, 77-78; Piwowarczyk 2002, 195, 210-211; Piwowarczyk 1998, 57-59), it could be tentatively proposed that the Szczerbiec may have been a knighting sword of Bolesław. No matter whether the rather extravagant form of the weapon was designed by Przemysł I or even by his father Władysław (before his death in 1239), the event would nicely fit into the proposed dating of the Szczerbiec. The authors of the present paper have not encountered any testimony of the Historia Karoli Magni by Pseudo-Turpin being known in Poland at that time. On the other hand, the idea of Duke Przemysł I having designed a Durendal sword for his younger brother is extremely tempting. It must be stressed, however, that this assumption can be treated as a mere hypothesis only, which will prove impossible to confirm or deny.

\section{CONCLUSIONS}

The following conclusions may be drawn concerning the Szczerbiec:

1. The weapon is a genuine medieval sword and not a $19^{\text {th }}$ c. replica. The blade manufacturing technology (quenched and tempered semi-hard steel) meets all the requirements of a weapon of war.

2. The slot in the upper part of the blade is in all probability a result of corrosion. Although the original shape of the blade cannot be fully reconstructed, it may be assumed that it was longer and considerably broader, perhaps with an ogival point. This is based on the traces left by subsequent cleaning processes.

3. The pommel and the crosspiece are made of gold-coveted silver. These parts of the hilt display the same stylistic features and they were most probably made by the same hand. Furthermore, the scope of the traces of wear is similar.

4. The front plates of the grip with were made by a different artist than that who worked on the pommel and the crosspiece. Furthermore, each of them was most probably made by a different hand. In the case of the front plates the degree of wear and damage is much smaller.

5. A combination of epigraphical, stylistic and typological criteria suggest a date of c. 1250 for the sword. Furthermore, the construction details of the lavishly ornamented and inscribed all-metal hilt suggest that the Szczerbiec may have been influenced by 
swords of the Mediterranean (Iberian in particular) cultural sphere. The most relevant analogies are the swords of Sancho IV of Castille and Léon, of Santa Casilda, of Friedrich II von Hohenstaufen (this one concerning the rectangular cross-section of the grip), of the Comtés de Dreux and a sword from the Museo Arqueológico Nacional in Madrid. The Iberian relation seems to be additionally confirmed by the presence of $\mathbf{A}$ and $\boldsymbol{\Omega}$ symbols on the pommel, which links the Szczerbiec to the Durendal, as known from the mid-12 ${ }^{\text {th }}$ c. Historia Karoli Magni by Pseudo-Turpin.

6. The ornamentation and inscription program provides the sword with features of a protective talisman. This was, apart from being a «gladius iustitiae» the original function of the weapon. On the other hand, an original relation of the Szczerbiec to Knights Templar is rather to be excluded.

7. The Szczerbiec in all probability originally belonged to Duke Bolesław Pobożny of Great Poland (died 1279). He was then inherited by Duke Władysław Łokietek, perhaps through marriage to Bolesław's daughter Jadwiga in 1293. Władysław was most probably the first to have used the sword as a coronation insignia.

Furthermore, several suggestions for further research may be proposed:

1. Further technological examinations of the hilt need to analyse the chemical composition of gold and silver in the pommel and the crosspiece, as well as the chemical composition of the niello substance. Moreover, a micro-sounder examination of the interior of the pommel is recommended. Furthermore, an extensive traseological examination of the crosspiece may address the issue of possible $19^{\text {th }}$ c. restorations of the inscriptions, as suggested by W. Semkowicz (Semkowicz 2002, 502).

2. Due to time constraints, no extensive research of the heraldic shield was carried out. Both microscopic observations and a surface penetration with a preparation needle demonstrated, that the surface is not covered by enamel (as hitherto assumed), but by red oil paint. Further examination will most surely yield more results.

3. Concerning a putative discontinuity in the middle of the thickness of the blade, this issue may be clarified by technological examinations (surface polishing and microstructure observations) of the other side of the blade, as well as by additional flaw detector analysis.

4. Provided that it will be possible to dismantle the hilt, an extensive examination of the interior of the grip will be feasible. Furthermore, a non-destructive examination of the cross-section of the blade near the tang may be feasible.

5. Finally, more research is no question necessary regarding new stylistic and epigraphical analogies. Special attention must be paid to tracing the origin of the putative Hebrew or Hebrew-Latin inscription on the crosspiece. More work also needs to be done concerning the origin of the Szczerbiec.

The authors of the present paper firmly believe that such a particular weapon fully deserves an extensive research program on its own. It must involve specialists from several fields and the results need to be published in a monograph. 


\section{BIBLIOGRAPHY}

\section{Sources}

Anonymous (1952), Galli Anonymi Cronicae et gesta ducum sive principum Polonorum. Ed. Maleczyński, K. Monumenta Poloniae Historica. Nova series. T. 2. Cracoviae.

Annales Poloniae Maioris (1962). Ed. Kürbis, B. Monumenta Poloniae Historica. Nova series. T. 6. Varsaviae.

Bible of Maciejowski (1975). Ed. by Cockerell, S. C., and J. Plummer. Old Testament Chronica Poloniae Maioris (1970). Ed. Kürbis, B. Monumenta Poloniae Historica. Nova series. T. 8. Varsaviae.

Codex Diplomaticus Maioris Poloniae 1 (984-1287), ed. Łebiński, W. et al., Posnaniae

Coin Archives. www.coinarchives.com. Keyword: Tripoli. Accessed September 2009.

Długosz, J. Johanni Dlugossi seu Longini canonici Cracoviensis Historiae Polonicae Libri XII. Instruxit Pauli, Ż. I. W Joannis Dlugosz Senioris canonici Cracoviensis Opera Omnia. Ed. Przeździecki, A. T. 4: Libri 11-12, Cracoviae 1877; T. 5: Liber 12 (13), Cracoviae 1878.

Długosz, J. Annales seu Cronicae Incliti Regni Poloniae. Lib. 1-2, ed. Dąbrowski, J. et al., Warszawa 1964; Libri 3-4, ed. Budkowa, S. et al., Warszawa 1970; Libri 7-8, ed. Turkowska, D. et al., Warszawa 1975; Liber 9, ed. Budkowa, S. et al., Warszawa 1978; Liber 10, ed. Gawęda, S. et al. Warszawa 1985.

Durandus, C. 1237-1296 (1899). The Sacred Vestments. An English Rendering of the Third Book of the 'Rationale Divinorum Officiorum' of Durandus, Bishop of Mende. By Rev. T. H. Passmore. London.

Liber fundationis claustri Sancte Marie Virginis in Heinrichow czyli Ksiega Henrykowska (Liber fundationis claustri Sancte Marie Virginis in Heinrichow or the Book of Henryków) (1991). Ed. Pater, J. $2^{\text {nd }}$ ed. Wrocław.

Petri de Dusburg Chronicon terrae Prussiae (1861). Ed. Töppen, M. Scriptores Rerum Prussicarum 1, 3-219. Leipzig.

Petri Zittaviensis Cronica Aule Regie (1884) Ed. Emler, J. Fontes Rerum Bohemicarum 4. Pragae.

Rocznik matopolski (Annals of Little Poland) (1878). Ed. Bielowski, A. Monumenta

Poloniae Historica 3. Lwów.

Rocznik wielkopolski (Annals of Great Poland) (1878) Ed. Bielowski, A. Monumenta Poloniae Historica 3. Lwów.

Song of Roland (1919). Translated by Moncrief, S. Ch., London. Ed. by Killings, D. B. The Online Medieval and Classical Library (1995) http://omacl.org/Roland/.

Turpini Historia Karoli Magni et Rotholandi (1880). Ed. Castets, F. Publications spéciales de la Société pour L’Étude des Langues Romanes. Septiéme Publication. Montpellier.

Vita Sancti Stanislai Cracoviensis episcopi (Vita maior) (1884). Ed. Kętrzyński, W. Monumenta Poloniae Historica 4.

Wincenty called Kadłubek (1994). Magistri Vincentii dicta Kadtubek Chronica Polonorum. Ed. Plezia, M. Monumenta Poloniae Historica. Nova series. T. 11. Cracoviae.

\section{Scholarship}

Aleksić, M. (2007). Mediaeval swords from southeastern Europe. Material from $12^{\text {th }}$ to

Askanas, K. Sztuka płocka (Płock art). Płock 1991.

Beaumont, E. de (1878). «Les armures et les armes anciennes au Trocadero.» Gazette des Beaux Arts 18.2, 702-718.

Bochnak, A., Pagaczewski, J. Polskie rzemiosto artystyczne wieków średnich (Polish artistic craftsmanship of the Middle Ages). Kraków 1959.

Bohak, G. (2003) «Hebrew, Hebrew Everywhere? Notes on the Interpretation of Voces Magicae.» In Noegel, S., Walker, J., Wheeler, B. (eds) Prayer, Magic and the Stars in the Ancient and Late Antique World. The Magic in History Series. University Park, Pennsylvania, 69-81.

Barański, M. (2003) «Książeta i społeczeństwo wobec zjednoczenia Polski na przełomie XIII i XIV wieku» (Dukes and the society versus the unification of Poland at the turn of the 13th and the 14th centuries) In Fałkowski, W. (ed) Polska około roku 1300. Państwo, społeczeństwo, kultura (Poland c. 1300. The state, the society and the culture). Warszawa, 9-56. 
Bauer, M. (2003) Templariusze. Mity i rzeczywistość (Polish translation of Die Tempelritter: Mythos und Wahrheit, 1997). Wrocław.

Borrmann, S. (1995) «C16c Silberring Kaisers Lothars III. von Süpplingenburg (+1137).» In Luckhardt, J., Niehoff, F. (eds) Heinrich der Löwe und seine Zeit. Herrschaft und Representation der Welfen 1125-1235. Bd. 1 Katalog. München, 148-149.

Brandt, M. (1995) «G32 Evangeliar aus St. Godehard.» In Luckhardt, J., Niehoff, F. (eds) Heinrich der Löwe und seine Zeit. Herrschaft und Representation der Welfen 1125-1235. Bd. 1 Katalog. München, 512-516.

Brepohl, E. (1987) Theophilus Presbyter und die mittelalterliche Goldschmiedekunst. Leipzig.

Bruhn-Hoffmeyer, A. (1982) «Arms and Armour in Spain II. A Short Survey. From the End of the $12^{\text {th }}$ Century to the Beginnings of the $15^{\text {th }}$ Century.» Gladius Tomo Especial (1981) .

Bruhn-Hoffmeyer, A. (1954) Middelalderens tveaeggede svaerd (Medieval two-edged sword) 2. Cøbenhavn.

Budzioch, D., Tomal, M. (2010) «A Hebrew inscription on the Polish coronation sword» Scripta Iudaica Cracoviensia 8, 39-47.

Catalogo historico-descriptivo de la Real Armeria de Madrid por el Conde V.do de Valencia de Don Juan (1898). Madrid.

Carpegna, N. di (1969) Antiche armi dal sec. IX al XVIII gia Collezione Odescalchi. Roma.

Casas, J. G. de las (1857). Anales de la paleografia española. Parte Primera, T.1. Madrid.

Chodyński, A. R. (2007) «Szczerbiec - miecz koronacyjny królów polskich» (The Szczerbiec - the coronation sword of the kings of Poland). In Trupinda, J. (ed) Imagines potestatis. Insygnia i znaki władzy w Królestwie Polskim i Zakonie Niemieckim. Katalog wystawy w Muzeum Zamkowym w Malborku 8 czerwca - 30 września 2007 roku (Imagines potestatis. Insignia and signs of power in the Kingdom of Poland and the Teutonic Order. The catalogue of the exhibition at the Castle Museum in Malbork, 8 June-30 September 2007). Malbork, 191-194.

Ciampi, S. (1819). «Gladius antiqui operis illustratur.» In Feriae Varsavienses sive quae vacans ab academicis lectionibus scribebat mense Augusto anni MDCCCXIX Sebastianus Ciampi... Varsaviae, 3-10.

Ciechanowski, K. (1965) Epigrafika romańska i wczesnogotycka w Polsce (Romanesque and early Gothic epigraphy in Poland). Wrocławskie Towarzystwo Naukowe. Rozprawy Komisji Historii Sztuki IV. Wrocław.

Coins of the Crusades (2005) A. H. Baldwin \& Sons Ltd. April 2005. London.

Croix, A. de la (2006) Templariusze. W sercu wypraw krzyżowych (Polish translation of Les Templiers: au coeur des croisades, 2002). Poznań.

Dalewski, Z. (2007) «Polski ceremoniał koronacyjny - Polish coronation ceremonial.» In Trupinda, J. (ed) Imagines potestatis. Insygnia i znaki władzy w Królestwie Polskim i Zakonie Niemieckim. Katalog wystawy w Muzeum Zamkowym w Malborku 8 czerwca - 30 września 2007 roku (Imagines potestatis. Insignia and signs of power in the Kingdom of Poland and the Teutonic Order. The catalogue of the exhibition at the Castle Museum in Malbork, 8 June - 30 September 2007). Malbork, 77-100.

Dalewski, Z. (1996) Władza, przestrzeń, ceremoniał. Miejsce i uroczystość inauguracji władcy w Polsce średniowiecznej do końca XIV w. (Power, space, ceremony. The place and the ceremony of inauguration of power in medieval Poland to the end of the $14^{\text {th }} \mathrm{c}$.) Warszawa.

Derwich, M. (1995) «Sachsen und Polen im. 12 Jahrhundert» In Luckhardt, J., Niehoff, F. (eds) Heinrich der Löwe und seine Zeit. Herrschaft und Representation der Welfen 1125-1235. Bd. 2. München, 136-143.

Długopolski, E. (1951) Władystaw Łokietek na tle swoich czasów (Władysław Łokietek against the background of his times). Wrocław.

Dworzaczek, W. (1959) Genealogia (Genealogy) Warszawa.

Engel, P. (2001). The realm of St Stephen. A History of Medieval Hungary, 895-1526. London-New York.

Favreau, R. (2007) «Des inscriptions pour donner sens. Épigraphie de l'art mosan.» In Bossche, B. van den, Barlet, J. (eds) L'art mosan. Liège et son pays à l'époque romane du XIe au XIIIe siècle. Alleur, 237-243. 
Folda, J. (2005) Crusader Art in the Holy Land, from the Third Crusade to the Fall of Acre, 1187-1291. Cambridge.

Förstner, D. (1990) Świat symboliki chrześcijańskiej (Polish translation of Welt der christlicher Symbole, 1977). Warszawa.

François, G. (1995) «D 102 Vortragekreuz.» In Luckhardt, J., Niehoff, F. (eds) Heinrich der Löwe und seine Zeit. Herrschaft und Representation der Welfen 1125-1235. Bd. 1 Katalog. München, 305307.

Fuguet i Sans, J., Plaza C. (2005) Los templarios en la Peninsula Iberica. Barcelona.

Fuhrmann, H. (2001) «Bildprogramm und Inschriften des Werbener Kelchs und der zugehörigen Patene» In Seyderhelm, B. (ed) Goldschmiedekunst des Mittelalters. Leipzig, 88-109.

Gładysz, M. (1998) «Udział Polski w V krucjacie lewantyńskiej (1217-1221)» (Poland's participation in the $5^{\text {th }}$ Levantine crusade, 1217-1221). In Śliwiński, B. (ed.) Szlachta, starostowie, zaciężni (Noblemen, captains, mercenaries). Gdańskie Studia z Dziejów Średniowiecza 5. Gdańsk-Koszalin, 63-82.

Gładysz, M. (2002) Zapomniani krzyżowcy. Polska wobec ruchu krucjatowego w XII-XIII w. (Forgotten crusaders. Poland and the crusade movement in the $12^{\text {th }}$-the $13^{\text {th }}$ centuries). Warszawa.

Głosek, M. (1984) Miecze środkowoeuropejskie $z X-X V w$. (Central European swords of the $10^{\text {th }}$-the $15^{\text {th }}$ c.) Polska Akademia Nauk. Instytut Historii Kultury Materialnej. Warszawa.

Głosek, M. (1973) Znaki i napisy na mieczach średniowiecznych w Polsce (Marks and inscriptions on medieval swords in Poland). Polska Akademia Nauk. Instytut Historii Kultury Materialnej. Wrocław.

Gradowski, M., Pielas, M. (2006) Katalog złotnictwa w zbiorze dokumentacji specjalistycznej Krajowego Ośrodka Badań i Dokumentacji Zabytków w Warszawie. Cz. 1-2 (Catalogue of goldsmithing at the collection of specialist documentation of the National Centre for Research and Documentation of Monuments). Part 1-2. Warszawa.

Gumowski, M. (1962) «Monety hebrajskie za Piastów» (Hebrew coins in the times of the Piasts). Biuletyn Żydowskiego Instytutu Historycznego 41, 3-19; 42, 3-44.

Gumowski, M. (1959) «Szczerbiec - polski miecz koronacyjny» (The Szczerbiec - the Polish coronation sword) Małopolskie Studia Historyczne 2.2.3, 5-18.

Haisig, M. (1963) «Recenzja M. Gumowskiego - 'Szczerbiec - polski miecz koronacyjny’» (A review of M. Gumowski’s 'The Szczerbiec - the Polish coronation sword') Studia Źródtoznawcze 8, 218219.

Hubert, L. (1861) Pamiętniki historyczne (Historical diaries) 1. Warszawa.

Huther, H. (2007) Die Passauer Wolfsklingen. Legende und Wirklichkeit. Passau.

Jasiński, K. (1997) «Kielich płocki z pateną - dar księcia mazowieckiego Konrada I» (The Płock chalice with the patene - a gift of Duke Konrad I of Masovia). In Michałowski, R. (ed) Człowiek w społeczeństwie średniowiecznym (Man in the medieval society). Warszawa, 283-297.

Jasiński, K. (1995) «Genealogia Piastów wielkopolskich. Potomstwo Władysława Odonica» (Genealogy of Great Poland's Piasts. Descendants of Władysław Odonic). Kronika miasta Poznania, z. 2, 34-66.

Jewish Encyclopedia On-Line (Accessed 2008) www.JewishEncyclopedia.com.

Jurek, T. (1992-1993). «Żydzi w późnośredniowiecznym Kaliszu» (Jews in late medieval Kalisz). Rocznik Kaliski 24, 29-53.

Kiersnowski, R. (1988) Moneta w kulturze wieków średnich (Coins in the culture of the Middle Ages). Warszawa.

Kiersnowski, R. (1964) Wstęp do numizmatyki polskiej wieków średnich (Introduction to Polish numismatics of the Middle Ages). Warszawa.

Kirschbaum, E. (ed.) (1968-1972) Lexikon der christlichen Ikonografie. Bd. 1 (1968), Bd. 2 (1970), Bd. 3 (1971), Bd 4 (1972). Rom-Freiburg-Basel-Wien.

Kopera, F. (1904) Dzieje Skarbca Koronnego czyli insygniów i klejnotów koronnych Polski (A history of the Royal Treasury or the coronation insignia of Poland). Kraków.

Kopera, F. (1917) «O napisach na mieczu koronacyjnym królów polskich» (Inscriptions on the coronation sword of the kings of Poland) Wiadomości Numizmatyczno-Archeologiczne 9, 229-232; 10, 250-251; 11, 256-257. 
Kossecka, T. (1999) Gabinet Rycin króla Stanisława Augusta (Cabinet of Drawings of King Stanisław August). Warszawa.

Kovács, E. (1974) Romanische Goldschmiedekunst in Ungarn. Budapest.

Kowalska, Z. (1998) «Die großpolnischen und schlesischen Judenschutzbriefe des 13. Jahrhunderts im Verhältnis zu den Privilegien Kaiser Friedrichs II. (1238) und Herzog Friedrichs II. von Österreich (1244)» Zeitschrift für Ostmitteleuropa-Forschung 47.1, 1-20.

Kraszewski, K. (1879) «W sprawie Szczerbca Bolesławowego» (Concerning the Szczerbiec of Bolesław). Biblioteka Warszawska, 1-12.

Krzyżaniakowa, J. (1975) «Rola kulturalna Piastów w Wielkopolsce» (Cultural role of the Piasts in Great Poland) In Piastowie w dziejach Polski (Piasts in the history of Poland). Wrocław, 167-195.

Kuczyński, S. K. (1961) «O polskim mieczu koronacyjnym» (The Polish coronation sword). Przeglad Historyczny 3.3, 562-577.

Künstler, G. (1968) Romanische Kunst im Abendland. Wien-München 1968.

Kürbisówna, B. (1965) »Inskrypcje» (Inscriptions) Stownik Starożytności Stowiańskich (Dictionary of Slavonic antiquities) 2.2, 273-274.

Laking, G. (1920) A Record of European Armour and Arms Through Seven Centuries 1. London.

Lenc, E. (1908). Imperatorski Ermitaž. Ukazatel'otdelenia srednih vekov i epohi vozroždena. Č. 1 Sobrane oruža. (The Imperial Hermitage. A guide through the departments of the Middle Ages and the Renaissance. P. 1. Arms and armour collection). S. Peterburg.

Lemeunier, A. (2007a) «De la Meuse à l'art mosan. Ingrédients et aléas d'un concept.» In Bossche, B. van den, Barlet, J. (eds) L'art mosan. Liège et son pays à l'époque romane du XIe au XIIIe siècle. Alleur, 11-33.

Lemeunier, A. (2007b) «L'orfèvrerie mosane.» In Bossche, B. van den, Barlet, J. (eds) L'art mosan. Liège et son pays à l'époque romane du XIe au XIIIe siècle. Alleur, 107-131.

Lileyko, J. (1987) Regalia polskie (Polish regalia). Warszawa.

Luckhardt, J. (1995) «E11 Reichsschwert und Scheide, Zeremonialschwert und Seidengürtel.» In Luckhardt, J., Niehoff, F. (eds) Heinrich der Löwe und seine Zeit. Herrschaft und Representation der Welfen 1125-1235. Bd. 1 Katalog. München, 343-344.

Ławrynowicz, O. (2005) Treści ideowe broni rycerskiej w Polsce wieków średnich (Ideological meanings of knightly armament in medieval Poland). Acta Archaeologica Lodziensia 51. Łódź.

Łepkowski, J. (1881) «Szczerbiec» Czas 225: 2-3.

Mâle, E. (1947) L'art religieux du XIIe siècle en France. Étude sur les origines de l'iconographie du Moyen Age. Paris.

Muchowski, P. (2006-2007) «Hebrew inscription on the Polish coronation sword?» Folia Orientalia 42-43, 231-236.

Mühlemann, J. (2000/2001) «Opowieść o rycerzu Ereku zachowana na krzyżu z diademów w skarbcu katedry krakowskiej na Wawelu» (Story of Knight Erec preserved on the cross of diadems at the Treasury of the Kraków Cathedral in Wawel). Studia Waweliana 9/10, 5-40.

Müller, M. (1995) «D 100 Reliquienkästchen der hl. Valeria.» In Luckhardt, J., Niehoff, F. (eds) Heinrich der Löwe und seine Zeit. Herrschaft und Representation der Welfen 1125-1235. Bd. 1 Katalog. München, 303-305.

Müller, H., Kölling, H. (1981) Europäische Hieb-und Stichwaffen aus der Sammlung des Museums für Deutsche Geschichte. Berlin.

Nadolski, A. (1992) «Jeszcze raz o Szczerbcu» (Once again about the Szczerbiec). Materiaty Muzeum Wnętrz Zamkowych w Pszczynie 7, 219-225.

Nadolski, A. (1969) »Szczerbiec - the Polish Coronation Sword.» The Journal of the Arms and Armour Society $6.6,183-184$.

Nadolski, A. (1968) »Szczerbiec - próba analizy bronioznawczej» (Szczerbiec - an attempt at a weaponry analysis). In Na granicach archeologii (At the frontiers of archaeology). Acta Archaeologica Lodziensia 17, 105-127.

Nicholson, H. (2005) Rycerze templariusze (Polish translation of The Knights Templar: A New History, 2001). Warszawa.

Nicolle, D. (2002) «Two swords from the foundation of Gibraltar.» Gladius 22, 147-200.

Nicolle, D. (1999) Arms and Armour of the Crusading Era, 1050-1350. Western Europe and the Crusader States. London. 
Nicolle, D. (1988a) Arms and Armour of the Crusading Era, 1050-1350. Vol. 1 Commentary. New York.

Nicolle, D. (1988b) Arms and Armour of the Crusading Era, 1050-1350. Vol. 2 Illustrations. New York.

Niemcewicz, J. U. (1839) Zbiór pamiętników o dawnej Polszcze (A collection of diaries on Old Poland) 3. Lipsk.

Nowacki, B. (1997) Przemyst II (1257-1296). Odnowiciel korony polskiej (Przemysł II, 1257-1296. The restorer of the crown of Poland). Poznań.

Nowacki, D. (2008) «Trzy arcydzieła średniowiecznego złotnictwa w Krakowie i Płocku: krzyż z koron, herma św. Zygmunta, relikwiarz na głowę św. Stanisława» (Three masterpieces of medieval goldsmithing in Kraków and Płock: the cross of crowns, the herm of St Sigismund, the reliquary of St Stanisław's head). In Grzybkowski, A., Żygulski jr., Z., Grzybkowska, T. (eds) Urbs celeberrima. Ksiega pamiatkowa na 750-lecie lokacji Krakowa (Urbs celeberrima. Festschrift on the $750^{\text {th }}$ anniversary of the location of Kraków). Kraków, 281-308.

Oakeshott, E. (2002). «The sword of the Comté de Dreux: non-Christian symbolism and the medieval European sword.» In Nicolle, D. (ed) A Companion to Medieval Arms and Armour. Ed. David Nicolle, 37-44. Woodbridge.

Oakeshott, E. (2000a) The Records of the Medieval Sword. $2^{\text {nd }}$ ed. Woodbridge.

Oakeshott, E. (2000b) Sword in Hand. Arms and Armour Inc.

Oakeshott, E. (1964) The Sword in the Age of Chivalry. Woodbridge.

Petzold, A. (1995) Romanische Kunst. Köln.

Piech, Z. (1994) «Symbole władzy i państwa w monarchii Władysława Łokietka i Kazimierza Wielkiego» (Symbols of power and state in the monarchy of Władysław Łokietek and Kazimierz Wielki). In Banaszkiewicz, J. (ed) Imagines potestatis. Rytuaty, symbole i konteksty fabularne wtadzy zwierzchniej. Polska X-XIV w. (Imagines potestatis. Rites, symbols and narrative contexts of sovereign power. $10^{\text {th }}-14^{\text {th }} \mathrm{C}$. Poland). Warszawa, 117-150.

Piwowarczyk, D. (2002) «Funkcje i ceremoniał pasowania rycerskiego na ziemiach polskich (XI-XVIII wiek)» (Functions and ceremony of knighting in the Polish lands. The $11^{\text {th }}$-the $18^{\text {th }}$ centuries). In Dąbrowska, M., Klonder, A. (eds) Od narodzin do wieku dojrzatego. Dzieci i młodzież w Polsce (From birth to adulthood. Children and youth in Poland) 1: Od średniowiecza do wieku XVIII (From the Middle Ages to the $18^{\text {th }}$ century). Warszawa, 192-217.

Piwowarczyk, D. (1998) Obyczaj rycerski w Polsce późnośredniowiecznej (XIV-XV wiek) (Chivalry culture in late medieval Poland. The $14^{\text {th }}$-the $15^{\text {th }}$ centuries). Warszawa.

Pleiner, R. (2006) Iron in Archaeology. Early European Blacksmiths. Archeologický ústav AVČR. Praha.

Plezia, M. (1996) «Legenda o Szczerbcu Chrobrego» (The legend of the Szczerbiec of Chrobry). In Michałowska, T. (ed) Wyobraźnia średniowieczna (Medieval imagination) Warszawa, 195-204.

Prinke, R. T. (1983) «The Jagged Sword and Polish Rosicrucians.» Journal of Rosicrucian Studies 1, 8-13 www.levity.com/alchemy/sword.html.

Radzikowski, W. E. (1898) Szczerbiec miecz Bolesławowski (The Szczerbiec - the sword of Bolesław). Kraków.

Robinson, J. (2008). Masterpieces. Medieval Art. The British Museum Press.

Rokosz, M. (1994) «Polskie insygnia koronacyjne w średniowiecznych fabułach» (Polish coronation insignia in medieval narratives) In Banaszkiewicz, J. (ed) Imagines potestatis. Rytuaty, symbole $i$ konteksty fabularne władzy zwierzchniej. Polska X-XIV w. (Imagines potestatis. Rites, symbols and narrative contexts of sovereign power. $10^{\text {th }}-14^{\text {th }} \mathrm{c}$. Poland). Warszawa, 206-227.

Rokosz, M. (1988) «Legenda Szczerbca» (The legend of the Szczerbiec). Studia Historyczne 31.1, 3-20.

Rożek, M. (1987) Polskie koronacje i korony (Polish coronations and crowns). Kraków

Sachs, R. (1984) «Narracja na średniowiecznych diademach turniejowych» (Narrative on medieval tournament diadems) Poznańskie Towarzystwo Przyjaciót Nauk. Wydział Nauk o Sztuce 102, 38-41.

Sadowski, J. N. (1894) «Miecz koronacyjny polski «Szczerbcem» zwany» (The Polish coronation sword known as the «Szczerbiec»). Rozprawy Akademii Umiejętności. Wydzial Historyczno-Filologiczny. Seria II, t. 5, 62-121. 
Sawicki, T. (1990) «Sprawozdanie z badań wykopaliskowych na Górze Lecha w Gnieźnie przy ul. Kolegiaty 4 (stanowisko 15 D) w 1984 roku. Wstępna analiza stratygraficzno-chronologiczna» (Report on excavations on the Mountain of Lech in Gniezno, Kolegiaty St. 4, Site 15D. Introductory stratigraphic and chronological analysis). Gniezno. Studia i materiały historyczne 3, 309-323. Warszawa-Poznań.

Scholem, G. G. (1996) Kabała i jej symbolika (A Polish translation of Zur Kabbala und ihrer Symbolik 1960). Kraków.

Seidel, M. (2005) Italian Art of the Middle Ages and the Renaissance 2. Venice.

Seitz, H. (1965) Blankwaffen. Geschichte und Typenentwicklung im europäischen Kulturbereich. Von der prähistorischen Zeit bis zum Ende des 10. Jahrhunderts. Bd. I. Bibliothek für Kunst-und Antiquitätenfreunde, Bd. IV Blankwaffen. Braunschweig.

Semkowicz, W. (2002) Paleografia łacińska (Latin palaeography) $2^{\text {nd }}$ ed. Kraków.

Smolikowski, S. (1879) «Opis i rysunek miecza znajdującego się na wystawie paryskiej w roku 1878, oraz kilka uwag w sprawie Szczerbca Bolesławowego» (A description and a drawing of the sword from the Paris exhibition in 1878, and some remarks on the Szczerbiec of Bolesław). Biblioteka Warszawska, 12-36.

Sobolewski, J. P. (1998) «Szczerbiec, insygnium-amulet Bolesława Pobożnego» (The Szczerbiec - the insignia and the amulet of Bolesław Pobożny (the Pious)) Fasciculi Historici Novi 2: 71-94.

Soler del Campo, A. (1993) La evolucion del armamento medieval en el reino castellano-leones y alAndalus (siglos XII-XIV). Madrid.

Soroka, E. (1990) «Romańskie płytki ceramiczne z Gniezna» (Romanesque pottery tiles from Gniezno) Gniezno. Studia i materiaty historyczne 3, 59-101. Warszawa-Poznań.

Spieralski, Z. (1974) «O mieczach krzyżackich spod Grunwaldu» (The Teutonic swords from Grunwald). Zapiski Historyczne 39.2, 23-29.

Starnawska, M. (2004) «Templariusze na ziemiach polskich» (Knights Templar in the Polish lands) In Majoch, S. (ed) Templariusze. Historia i mit. Katalog wystawy. (Knights Templar: history and myth. An exhibition catalogue). Toruń, 19-25.

Starnawska, M. (1991). Między Jerozolima a Lukowem. Zakony krzyżowe na ziemiach polskich $w$ średniowieczu (Between Jerusalem and Łuków. Military orders in the Polish lands in the Middle Ages). Warszawa.

Świechowski, Z., Świechowska, E. (2004) Sztuka polska. Romanizm (Polish art - the Romanesque). Warszawa.

Świechowski, Z. (1983) Romanesque Art in Poland. Warszawa.

Świeżawski, A. (2006) Przemysł król Polski (Przemysł King of Poland). Warszawa.

Thomas, B, Gamber, O., Schedelmann, H. (1981) Die Schönsten Waffen und Rustungen aus europäischen und amerikanischen Sammlungen. Wiesbaden.

Trachtenberg, J. (1939) Jewish Magic and Superstition. A Study in Folk Religion. Reprint 2008 www. forgottenbooks.com.

Tylecote, R. F., Gilmour, B. J. J. (1986) The Metallography of Early Ferrous Edge Tools and Edged Weapons. B.A.R. British Series 155. Oxford.

Walicki, M. (1968) «Część V - Wyposażenie artystyczne dworu i kościoła» (Part V - Artistic furnishings of the court and the church) In Walicki, M. (ed) Sztuka polska przedromańska i romańska do schytku XIII wieku (Polish pre-Romanesque and Romanesque art to the end of the $13^{\text {th }}$ c.) 1. Dzieje Sztuki Polskiej (History of the Polish art) 1. Warszawa, 249-303.

Wątroba, P. (2007) «Świecki strój koronacyjny Stanisława Augusta plansza 2 - regalia» (Secular coronation robe of Stanisław August. Board 2 - the regalia) In Trupinda, J. (ed) Imagines potestatis. Insygnia i znaki wtadzy w Królestwie Polskim i Zakonie Niemieckim. Katalog wystawy w Muzeum Zamkowym w Malborku 8 czerwca - 30 września 2007 roku (Imagines potestatis. Insignia and signs of power in the Kingdom of Poland and the Teutonic Order. The catalogue of the exhibition at the Castle Museum in Malbork, 8 June - 30 September 2007). Malbork, 194-196.

Wesołowski, K. (1974) Metaloznawstwo i obróbka cieplna (Metallurgy and thermal treatment). Warszawa.

Wiesiołowski, J. (1995) «Przemysł-Lancelot, czyli Strażnica Radości nad Wartą» (Przemysł-Lancelot, or the Castle of Joy upon the River Warta) Kronika miasta Poznania, z. 2, 123-135. 
Wiesiołowski, J. (1993) «Romans rycerski w kulturze społeczeństwa późnośredniowiecznej Polski» (Chivalrous romance in the culture of the society of late medieval Poland). In Michałowska, T. (ed) Literatura i kultura późnego średniowiecza w Polsce (Literature and culture of the late Middle Ages in Poland). Warszawa, 141-151.

Zakrzewski, Z. (1926) «Gniezno i Kalisz - dwie mennice wielkopolskie za czasów Mieszka III» (Gniezno and Kalisz - two mints in Great Poland in the times of Mieszko III) Wiadomości Numizmatyczno-Archeologiczne 1-12, 2-51.

Żmudzki, P. (2000) Studium podzielonego królestwa. Książę Leszek Czarny (A study of a divided Kingdom. Duke Leszek Czarny (the Black)). Warszawa.

Żygulski jr, Z. (1975) Broń w dawnej Polsce. Na tle uzbrojenia Europy i Bliskiego Wschodu (Arms and armour in Old Poland. Against the background of the weaponry of Europe and the Middle East). Warszawa.

Żygulski jr, Z. (2008) «Szczerbiec.» In Grzybkowski, A., Żygulski jr., Z., Grzybkowska, T. (eds) Urbs celeberrima. Ksiega pamiatkowa na 750-lecie lokacji Krakowa (Urbs celeberrima. Festschrift on the $750^{\text {th }}$ anniversary of the location of Kraków). Kraków, 310-355.

Recibido: 26/05/2009

Aceptado: 27/04/3011 